\title{
EXTREME MEDICINE
}

\section{SCIENTIFIC AND PRACTICAL REVIEWED JOURNAL OF FMBA OF RUSSIA}

EDITOR-IN-CHIEF Veronica Skvortsova, DSc, professor, RAS corresponding member

DEPUTY EDITOR-IN-CHIEF Igor Berzin, Daria Kryuchko

EDITORS Vsevolod Belousov, Anton Keskinov

TRANSLATORS Ekaterina Tretiyakova, Vyacheslav Vityuk

DESIGN AND LAYOUT Marina Doronina

\section{EDITORIAL BOARD}

Agapov VK, DSc, professor (Moscow, Russia)

Baranov VM, member of RAS, DSc, professor (Moscow, Russia)

Bogomolov AV, DSc, professor (Moscow, Russia)

Bushmanov AY, DSc, professor (Moscow, Russia)

Daikhes NA, member of RAS, DSc, professor (Moscow, Russia)

Dubina MV, member of RAS, DSc, professor (Saint-Petersburg, Russia)

Dudarenko SV, DSc (Saint-Petersburg, Russia)

llyin LA, member of RAS, DSc, professor (Moscow, Russia)

Lobzin YV, member of RAS, DSc, professor (Saint-Petersburg, Russia)

Nikiforov VV, DSc, professor (Moscow, Russia)

Olesova VN, DSc, professor (Moscow, Russia)
Petrov RV, member of RAS, DSc, professor (Moscow, Russia) Sadilov AS, DSc, professor (Saint-Petersburg, Russia)

Rembovsky VR, DSc, professor (Saint-Petersburg, Russia)

Samoilov AS, member of RAS, DSc, professor (Moscow, Russia) Sergienko VI, member of RAS, DSc, professor (Moscow, Russia) Troitsky AV, DSc, professor (Moscow, Russia)

Ushakov IB, member of RAS, DSc, professor (Moscow, Russia) Khaitov MR, member of RAS, DSc, professor (Moscow, Russia) Khaitov RM, member of RAS, DSc, professor (Moscow, Russia) Chechetkin AV, DSc, professor (Saint-Petersburg, Russia) Yudin SM, DSc, professor (Moscow, Russia)

\section{ADVISORY BOARD}

Akleev AV, DSc, professor (Chelyabinsk, Russia) Arakelov SA, DSc, professor (Saint-Petersburg, Russia) Baklaushev VP, DSc, professor (Moscow, Russia) Degteva MO, PhD (Chelyabinsk, Russia) Efimenko NV, DSc, professor (Pyatigorsk, Russia) Kazakevich EV, DSc, professor (Arkhangelsk, Russia) Katuntsev VP, DSc, professor (Moscow, Russia Klimanov VA, DSc, professor (Moscow, Russia) Klinov DV, PhD (Moscow, Russia)

Koshurnikova NA, DSc, professor (Ozersk, Russia) Minnullin IP, DSc, professor (Saint-Petersburg, Russia)

\author{
Mosyagin IG, DSc, professor (Saint-Petersburg, Russia) \\ Panasenko OM, DSc, professor (Moscow, Russia) \\ Rogozhnikov VA, DSc, (Moscow, Russia) \\ Romanov SA, PhD (Ozersk, Russia) \\ Sotnichenko SA, DSc (Vladivostok, Russia) \\ Suranova TG, PhD, docent (Moscow, Russia) \\ Takhauov RM, DSc, professor (Seversk, Russia) \\ Shandala NK, DSc, professor (Moscow, Russia) \\ Shinkarev SM, DSc (Moscow, Russia) \\ Shipulin GA, PhD (Moscow, Russia) \\ Yakovleva TV, DSc (Moscow, Russia)
}

SUBMISSION editor@fmba.press

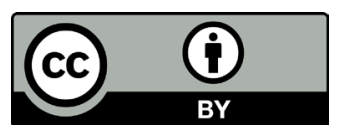

Approved for print 30.06.202 


\title{
МЕАИЦИНА ЭКСТРЕМААЬНЫХ СИТУАЦИЙ
}

\author{
НАУЧНО-ПРАКТИЧЕСКИЙ РЕЦЕНЗИРУЕМЫЙ ЖУРНАЛ ФМБА РОССИИ
}

ГЛАВНЫЙ РЕДАКТОР Вероника СКворцова, Д. М. Н., профессор, член-корреспондент РАН

ЗАМЕСТИТЕЛЬ ГЛАВНОГО РЕДАКТОРА ИГОрь БерЗИН, Дарья КрючКО

РЕДАКТОРЫ Всеволод Белоусов, Антон Кескинов

ПЕРЕВоДЧИКИ Екатерина Третьякова, Вячеслав Витюк

ДИЗАЙН И ВЕРСТКА Марины Дорониной

\section{РЕДАКЦИОННАЯ КОЛЛЕГИЯ}

В. К. Агапов, д. М. Н., профессор (Москва, Россия)

В. М. Баранов, д. М. Н., профессор, академик РАН (Москва, Россия)

А. В. Богомолов, д. т. н., профессор (Москва, Россия)

А. Ю. Бушманов, д. М. Н., профессор (Москва, Россия)

Н. А. Дайхес, д. М. Н., профессор, член-корр. РАН (Москва, Россия)

М. В. Дубина, д. М. Н., профессор, академик РАН (Санкт-Петербург, Россия)

С. В. Дударенко, Д. м. Н., доцент (Санкт-Петербург, Россия)

л. А. Ильин, д. М. Н., профессор, академик РАН (Москва, Россия)

Ю. В. Лобзин, д. м. н., профессор, академик РАН (Санкт-Петербург, Россия)

В. В. Никифоров, д. М. Н., профессор (Москва, Россия)

В. Н. Олесова, д. М. н., профессор (Москва, Россия)
Р. В. Петров, д. М. Н., профессор, академик РАН (Москва, Россия) А. С. Радилов, д. М. Н., профессор (Санкт-Петербург, Россия)

В. Р. Рембовский, д. М. Н., профессор (Санкт-Петербург, Россия)

А. С. Самойлов, д. М. Н., профессор, член-корр. РАН (Москва, Россия)

В. А. Сергиенко, д. М. Н., профессор, член-корр. РАН

А. В. Троицкий, д. М. Н., профессор (Москва, Россия)

И. Б. Ушаков, д. М. Н., профессор, академик РАН (Москва, Россия) М. Р. Хаитов, д. М. Н., профессор, член-корр. РАН (Москва, Россия)

Р. М. Хаитов, Д. М. Н., профессор, академик РАН (Москва, Россия)

А. В. Чечеткин, д. М. Н., профессор (Санкт-Петербург, Россия)

С. М. Юдин, д. М. н., профессор (Москва, Россия)

\section{РЕДАКЦИОННЫЙ СОВЕТ}

А. В. Аклеев, д. М. Н., профессор (Челябинск, Россия)

С. А. Аракелов, д. б. н., профессор (Санкт-Петербург, Россия)

В. П. Баклаушев, д. М. Н., профессор (Москва, Россия)

М. О. Дегтева, К. Т. Н. (Челябинск, Россия)

Н. В. Ефименко, Д. М. Н., профессор (Пятигорск, Россия)

Е. В. Казакевич, д. М. Н., профессор (Архангельск, Россия)

В. П. Катунцев, Д. М. Н., профессор (Москва, Россия)

В. А. Климанов, д. ф.-М. Н., профессор (Москва, Россия)

Д. В. Клинов, к. ф. М. Н., (Москва, Россия)

Н. А. Кошурникова, Д. М. Н., профессор (Озерск, Россия)

И. П. Миннуллин, Д. М. Н., профессор (Санкт-Петербург, Россия)
И. Г. Мосягин, д. м. н., профессор (Санкт-Петербург, Россия)

О. М. Панасенко, д. б. н., профессор (Москва, Россия)

В. А. Рогожников, д. М. Н. (Москва, Россия)

С. А. Романов, к. б. н. (Озерск, Россия)

С. А. Сотниченко, Д. М. Н. (Владивосток, Россия)

Т. Г. Суранова, к. М. Н., доцент (Москва, Россия)

Р. М. Тахауов, д. М. Н., просессор (Северск, Россия)

Н. К. Шандала, д. М. Н., профессор (Москва, Россия)

С. М. Шинкарев, д. т. н. (Москва, Россия)

Г. А. Шипулин, К. М. Н. (Москва, Россия)

Т. В. Яковлева д. М. Н. (Москва, Россия)

ПОДАЧА РУКОПИСЕЙ editor@fmba.press

ПЕРЕПИСКА С РЕДАКЦИЕЙ editor@fmba.press

СОТРУДНИЧЕСТВО manager@fmba.press

АДРЕС РЕДАКЦИИ Волоколамское шоссе, д. 30, стр. 1, г. Москва, 123182

Журнал включен в РИНЦ. IF 2018: 0,570

НАУЧНАЯ ЭАЕКТРОННАЯ БИБАИОТЕКА LIBRARY.RU
Журнал включен в Перечень 31.01.2020 (№ 1292)

ВЫСШАЯ

АТТЕСТАЦИОННАЯ

КОМИССИЯ (ВАК)
Здесь находится открытый архив журнала

\section{CYPERLEHIIIKA}

DOI выпуска: 10.47183/mes.2021-02

Свидетельство о регистрации средства массовой информации № ФС77-25124 от 27 июля 2006 года Учредитель и издатель: Федеральное медико-биологическое агентство fmba.gov.ru

Журнал распространяется по лицензии Creative Commons Attribution 4.0 International www.creativecommons.org

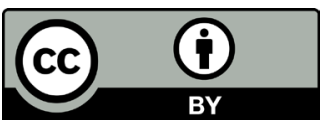

Подписано в печать 30.06.2021 


\section{Contents}

Содержание

Method for quantitative assessment of protective immunity against SARS-CoV-2, its duration and antibody dynamics Karmishin AM, Nosov NYu, Postupaylo VB, Zhigarlovsky BA, Kruglov AA, Petukhov AN

Метод количественной оценки напряженности и длительности иммунитета к SARS-CoV-2 и динамики изменения титров антител А. М. Кармишин, Н. Ю. Носов, В. Б. Поступайло, Б. А. Жигарловский, А. А. Круглов, А. Н. Петухов

\section{REVIEW}

Pediatric inflammatory multisystem syndrome temporally associated with SARS-CoV-2 infection Lobzin YuV, Uskov AN, Skripchenko NV, Vilinits AA, Bekhtereva MK, Babachenko IV

COVID-19-ассоциированный педиатрический мультисистемный воспалительный синдром Ю. В. Лобзин, А. Н. Усков, Н. В. Скрипченко, А. А. Вильниц, М. К. Бехтерева, И. В. Бабаченко

\section{ORIGINAL RESEARCH}

Evaluation of efficacy of the amino acid-peptide complex administered intragastrically to golden hamsters experimentally infected with SARS-CoV-2 Laptev DS, Protasova GA, Petunov SG, Radilov AS, Chepur SV, Gogolevskiy AS, Myasnikov VA, Tyunin MA, Smirnova AV

Оценка эффективности аминокислотно-пептидного комплекса при внутрижелудочном введении золотистым хомякам, экспериментально зараженным SARS-CoV-2

Д. С. Лаптев, Г. А. Протасова, С. Г. Петунов, А. С. Радилов, С. В. Чепур, А. С. Гоголевский, В. А. Мясников, М. А. Тюнин, А. В. Смирнова

Rehabilitation in oncology

Kamilova TA, Golota AS, Vologzhanin DA, Shneider OV, Scherbak SG

Реабилитация в онкологии

Т. А. Камилова, А. С. Голота, Д. А. Вологжанин, О. В. Шнейдер, С. Г. Щербак

Features of interlaboratory comparison methods when measuring vibroacoustic parameters Sterlikov AV, Kurilenko YuV, Voronkov AA

Особенности методов проведения межлабораторных сличений при измерении виброакустических показателей А. В. Стерликов, Ю. В. Куриленко, А. А. Воронков

ORIGINAL RESEARCH

The limitations and capabilities of wipe samples analysis in control of contamination of facilities with highly toxic organic compounds Shachneva MD, Leninskii MA, Savelieva El

Возможности и ограничения анализа смывов с поверхностей для контроля контаминации

объектов высокотоксичными органическими соединениями

М. Д. Шачнева, М. А. Ленинский, Е. И. Савельева

In vivo toxicity study of dialkyl disulphides

Kucherskoy SA, Alikbaeva LA

Токсичность диалкилдисульфидов в экспериментах in vivo

С. А. Кучерской, Л. А. Аликбаева

Experimental justification of the maximum possible concentration $(\mathrm{mpc})$ of dichlorohexafluorobutene in a working area Shkaeva IE, Dulov SA, Nikulina OS, Solnceva SA, Zemlyanoi AV

Экспериментальное обоснование предельно допустимой концентрации дихлоргексафторбутена в воздухе рабочей зоны И. Е. Шкаева, С. А. Дулов, О. С. Никулина, С. А. Солнцева, А. В. Земляной 
Hygienic assessment of the chemical weapons destruction facilities in the context of relieving the consequences of their operation and subsequent conversion thereof

Gulyaev DV

Гигиеническая оценка объектов по уничтожению химического оружия при ликвидации последствий деятельности и перепрофилировании Д. В. Гуляев

Organ-sparing excision of pediatric testicular teratoma

Poddubnyi IV, Tolstov KN, Fedorova EV, Trunov VO, Khanov MM, Malashenko AS, Sytkov W, Mager AO, Ranshakov AS

Органсберегающее удаление тератомы яичка у ребенка

И. В. Поддубный, К. Н. Толстов, Е. В. Федорова, В. О. Трунов, М. М. Ханов, А. С. Малашенко, В. В. Сытьков, А. О. Магер, А. С. Раншаков 


\title{
METHOD FOR QUANTITATIVE ASSESSMENT OF PROTECTIVE IMMUNITY AGAINST SARS-COV-2, ITS DURATION AND ANTIBODY DYNAMICS
}

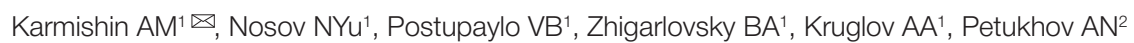

${ }^{1}$ Center for Strategic Planning and Management of Medical and Biological Health Risks of the Federal Medical Biological Agency, Moscow, Russia

${ }^{2}$ Military Academy of Radiation, Chemical and Biological Defense, Kostroma, Russa

The level and duration of protective immunity are often analyzed qualitatively or semi-quantitatively. The same strategy is applied to the analysis of antibody dynamics. At some point in time $t$ after exposure or immunization, the presence of immunity against the infection is inferred from the level of specific antibodies by comparing it to a reference value. This approach does not account for the stochastic nature of human disease after exposure to a pathogen. At the same time, it is not fully clear what antibody level should be considered protective. The aim of this study was to develop a mathematical model for quantitative determination of protective immunity against SARS-CoV-2 and its duration. We demonstrate that the problem of describing protective immunity in quantitative terms can be broken down into 2 interrelated problems: describing the quantitative characteristics of a pathogen's virulence (in our case, the pathogen is SARS-CoV-2) and describing the dynamics of antibody titers in a biological organism. Below, we provide solutions for these problems and identify parameters of the model which describes such dynamics. Using the proposed model, we offer a theoretical solution to the problem of protective immunity and its duration. We also note that in order to quantitatively determine the studied parameters in a homogenous population group, it is necessary to know 5 parameters of the bivariate probability density function for correlated continuous random variables: the infective dose of the pathogen and the antibody titer at which the disease develops and which are still unknown.

Keywords: SARS-CoV-2, COVID-19, infective dose, probability of disease, antibody titer, protective immunity, immunity duration

Author contribution: All authors equally contributed to the methodology of the study, data acquisition, analysis and interpretation. All author participated in drafting the manuscript and editing its final version.

$\triangle$ Correspondence should be addressed: Alexandr M. Karmishin

Shchukinskaya, 5/6, Moscow, 123182; akarmishin@cspmz.ru

Received: 25.05.2021 Accepted: 07.06.2021 Published online: 28.06.2021

DOI: $10.47183 /$ mes.2021.019

\section{МЕТОД КОЛИЧЕСТВЕННОЙ ОЦЕНКИ НАПРЯЖЕННОСТИ И ДЛИТЕЛЬНОСТИ ИММУНИТЕТА К SARS- COV-2 И ДИНАМИКИ ИЗМЕНЕНИЯ ТИТРОВ АНТИТЕЛ}

\author{
А. М. Кармишин ${ }^{1}$, Н. Ю. Носов ${ }^{1}$, В. Б. Поступайло ${ }^{1}$, Б. А. Жигарловский ${ }^{1}$, А. А. Круглов ${ }^{1}$, А. Н. Петухов ${ }^{2}$
}

${ }^{1}$ Центр стратегического планирования и управления медико-биологическими рисками здоровью Федерального медико-биологического агентства, Москва, Россия

2 Военная академия радиационной, химической и биологической защиты, Кострома, Россия

\begin{abstract}
Вопросы напряженности и длительности иммунитета зачастую рассматривают на качественном или полуколичественном уровнях. Практически аналогичную ситуацию можно наблюдать и при изучении динамики изменения уровня антител у населения. О наличии иммунитета на момент времени $t$ после инфицирования (вакцинации) судят по уровню антител в сравнении с их референсными значениями. Данный подход не учитывает стохастический характер заболевания человека при действии на него патогена. В то же время не вполне понятно, какой уровень защиты обеспечивает определенный уровень антител. Целью исследования было разработать математическую модель для количественного определения напряженности и длительности иммунитета к SARS-CoV-2. Показано, что описание напряженности и длительности иммунитета распадается на решение двух взаимосвязанных задач: 1) описание количественных характеристик вирулентности патогена и, в частности, SARS-CoV-2; 2) описание динамики изменения титров антител в организме биообъекта. Дается решение этих задач и по экспериментальным данным определяются параметры модели, описывающей динамику изменения титров антител. На базе разработанной модели представлено теоретическое решение задачи о напряженности и длительности иммунитета и отмечено, что для получения количественных оценок рассматриваемых показателей для каждой однотипной группы населения необходимо знать пять параметров двумерной плотности распределения коррелированных непрерывных случайных величин: инфицирующей дозы патогена и титра антител,
\end{abstract} при которых наступает заболевание и которые к настоящему времени неизвестны.

Ключевые слова: SARS-CoV-2, COVID-19, инфицирующая доза патогена, вероятность заболевания, титр антител, напряженность иммунитета, длительность иммунитета

Вклад авторов: все авторы внесли значимый вклад в разработку методики исследования, получение, анализ и интерпретацию данных, в написание и редактирование статьи.

Для корреспонденции: Александр Михайлович Кармишин ул. Щукинская, д. 5/6, г. Москва, 123182; akarmishin@cspmz.ru

Статья получена: 25.05.2021 Статья принята к печати: 07.06.2021 Опубликована онлайн: 28.06.2021

DOI: 10.47183/mes.2021.019

In December 2019, an outbreak of the respiratory disease caused by a novel coronavirus was reported in China. The infection rapidly spread across the globe. On February 11, the disease received its official name COVID-19 from WHO; at the same time, the International Committee on Taxonomy of Viruses named the novel pathogen SARS-CoV-2 [1]. On March 11, WHO declared a pandemic of the novel coronavirus disease.

SARS-CoV-2 is a representative of the Betacoronavirus genus from the Coronaviridae family. The virus has 4 major structural proteins: a spike protein $(S)$ consisting of 2 subunits $S_{1}$ and $S_{2}$; an envelope protein $(E)$; a membrane protein $(M)$, and a nucleocapsid protein $(N)$. The receptor-binding domain $(R B D)$ of $S_{1}$ mediates SARS-CoV-2 entry into the host cell. The nucleocapsid protein plays a significant role in viral transcription and assembly in the host cell. As a rule, neutralizing antibodies bind to the $R B D$ of the $S$ protein blocking the entry of the virus into the cell. At the same time, the mechanisms of interaction between the antibody and the $N$ protein are yet poorly studied $[2,3]$. 
During the first phase of modeling the COVID-19 epidemic, a method was proposed for determining the quantitative characteristics of SARS-CoV-2 spread in different countries [4-7].

According to experimental data, the dynamics of antibody production against any pathogen, including SARS-CoV-2, after exposure or immunization are characterized by the following pattern $[2,3,8]$ :

- the antibody titer rises;

- in a general case, the titer reaches a plateau level;

- the titer gradually wanes, falling to 0 in a general case or to some background value in a special case.

Immunity is a state in which the organism is not susceptible to infection. Almost every immunity can be overcome with massive doses of pathogen. Protective immunity can be measured as "the protective titer of neutralizing antibodies", i.e. the level of specific antibodies in the blood serum ensuring protection against the disease, which may develop following exposure to the pathogen. The "protective titer" is a relative concept. Notably, low antibody titers may confer some protection against the pathogen, whereas high antibody titers do not guarantee absolute protection against the disease [9].

This definition of protective immunity is very general and does not account for its quantitative characteristics.

Since the development of an infectious human disease is a stochastic process, protective immunity can be defined in stricter terms. It is the level (titer) of antibodies at which the probability of disease after exposure to the infective dose does not exceed a specified (forced) probability.

The duration of immunity is the time span during which protective immunity is sustained.

In order to calculate the protective level of antibodies and the duration of protective immunity, a mathematical model is needed that would describe the probability of an infectious human disease at a given antibody titer and antibody persistence after exposure to the infective dose. So, the problem of describing protective immunity in quantitative terms can be broken down into two interrelated problems:

- to mathematically reason the relationship between the dynamics of parameters of the hazard factor law, which describes the probability of infection in the human population, and the levels (titers) of antibodies against this infection;

- to build a mathematical model of antibody titer dynamics in a human organism.

So far, the level and duration of immune protection against SARS-CoV-2 following infection or immunization remain unknown; this fact is openly admitted by the developers of Russian and foreign vaccines and specified in the instructions for their use [10-14].

The aim of this study was to develop a mathematical model for quantitative determination of protective immunity against SARS-CoV-2 and its duration.

\section{METHODS}

The following theoretically or experimentally established factors were considered while developing a mathematical model of antibody titer dynamics:

1) all else being equal, the probability of an infectious human disease depends on the antibody titer: the higher the titer, the lower the probability;

2) antibody production is a stochastic process; consequently, the levels of a given antibody type will differ among individuals at a specific point in time following exposure to a given infective dose; in other words, antibody titers are a random variable;
3) in a human organism, antibody titers rise, then reach a plateau level and then wane to 0 or some background value;

4) protective immunity and its duration are determined by the level of specific antibodies.

Based on the methodological and scientific consensus, this study attempted to build a mathematical model describing the stochastic character of the novel coronavirus disease following exposure to its causative agent and the dynamics of antibody titers to SARS-CoV-2. This model could be instrumental in solving a number of important practical tasks, such as determining the level of protection against the infection and the duration of protective immunity.

This study used literature data on the results of testing for IgM and lgG against the $S$ and $N$ proteins and the $R B D$-fragment of the $S$-protein conducted on 1,850 patients hospitalized for COVID-19 [2]. Figures were prepared in Microsoft Office Excel 2013 (Microsoft; USA).

\section{RESULTS}

Using methods of differential and integral calculus and the probability theory, we developed a mathematical model describing the dynamics of antibody titers in human blood in order to solve the following tasks:

- to predict the dynamics of antibody titers in an infected or immunized population;

- to estimate the duration of an infectious disease that is at or above a specified severity level;

- to estimate the level of protection and the duration of protective immunity;

- to provide a rationale for vaccine requirements considering the purpose of vaccination.

It follows from fact 1 (the probability of an infectious disease depends on the antibody titer) that at any level of specific antibodies, e.g. IgG, the disease is probable; therefore, a bivariate probability density function for a random antibody titer and an infective dose causing the disease at this titer can be added to the analysis. Based on the previous theoretical and experimental research $[4,6,7,15]$, we conclude that the probability density function is described by a bivariate lognormal distribution:

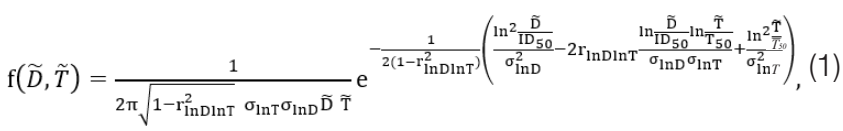

where $I D_{50}$ is a median of the random infective dose that causes a studied infectious disease at a titer $T_{50}$ with 0.5 probability; $T_{50}$ is an antibody titer median observed in biological objects of the same type (homogenous groups of humans); $\sigma / n D$, $\sigma_{\text {IntT }}$ a are mean squared errors of the natural logarithm of the random disease-inducing infective dose and the antibody titer, respectively; $r_{\ln \ln T}$ is a correlation coefficient for the natural logarithms of the random variables in question.

In the general case, the domain of the correlation coefficient is $[-1 ; 1]$, but in our case the correlation coefficient must be positive and defined in the interval $(0 ; 1]$ because the diseasecausing infective dose is expected to increase as the antibody titer rises.

It follows from equation (1) that if titer $T$ of $\operatorname{lgM}$ or IgG antibodies is a fixed value, then the random infective dose that causes a mild, moderate, severe or very severe infection will have a log-normal distribution:

$$
\mathrm{f}(\widetilde{D} / T)=\frac{1}{\sqrt{2 \pi} \widetilde{D} \sigma_{\ln D}^{*}} \mathrm{e}^{-\frac{\left(\ln \widetilde{D}-\ln I D_{50}^{*}\right)^{2}}{2 \sigma_{\ln D}^{* 2}}},
$$




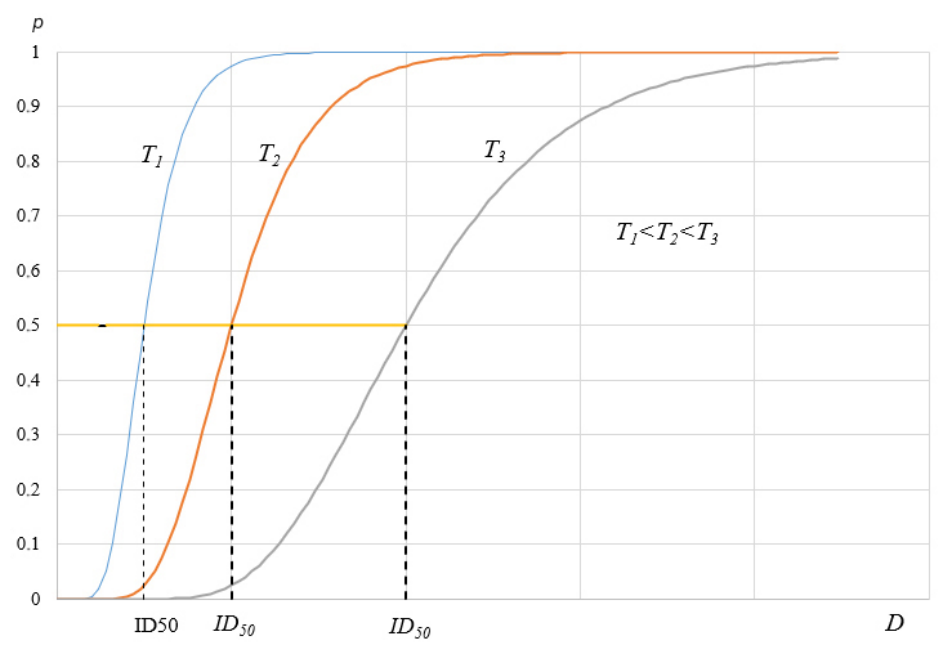

Fig. 1. The dependence of the hazard factor law on lgG antibody titers where $I D_{50}^{*}$ is a distribution law parameter: the median value of the random infective dose that causes a mild, moderate, severe or very severe infection at a given antibody titer;

$\sigma_{\ln D}^{*}$ is a mean squared error of the natural logarithm of the random infective dose that causes infection at a given antibody titer.

Parameters of the conditional probability distribution of a random variable $\widetilde{D}$ from the equation (2) can be expressed using the parameters of bivariate density distribution (1) and the fixed value of the antibody titer as follows $[16,17]$ :

$$
\ln D_{50}^{*}=\ln D_{50}+r_{\ln D \ln T} \frac{\sqrt{\mathrm{k}_{\ln T}}}{\sqrt{\mathrm{k}_{\ln D}}} \ln \frac{T}{T_{50}} ; \sigma_{\ln D}^{*}=\sqrt{1-r_{\ln D \ln T}^{2}} \sigma_{\ln T}
$$

From the conditional probability distribution of the random infective dose that causes the infectious disease of or above a specified severity level at a given antibody titer follows the socalled hazard factor law [4, 7], which describes the probability of a studied infectious disease at antibody titer $T$ depending on the applied infective dose:

$$
P=0,5\left[1+\operatorname{erf}\left(\sqrt{\mathrm{k}_{\ln D}^{*}} \ln \frac{D}{I D_{50}^{*}}\right)\right],
$$

$I D_{50}^{*}$ is a parameter of the law: the infective dose at which the probability of the onset of an infectious disease of severity at or above the specified level (mild, moderate, severe, very severe) at a given antibody titer equals 0.5 .

The relationship between the hazard factor law describing an infectious disease of severity at or above the specified level and the titer of IgG antibodies is schematically shown in Fig. 1.

It follows from the hazard factor law that the infective dose at which the infectious disease develops with the probability $p$ can be defined as shown below [15]:

$$
D_{p}=I D_{50}^{*}(T) \mathrm{e}^{\frac{\operatorname{argerf}(2 p-1)}{\sqrt{\mathrm{k}_{\operatorname{lnD}}^{*}}}},
$$

where $\operatorname{argerf}(\mathrm{u})$ is a function inverse to the integral of error function [13].

Thus, in order to determine the probability $p$ of developing an infectious disease and the probability $1-p$ of not developing this infectious disease after exposure to the infective dose $D$, we need to know the point in time after exposure when the IgG antibody titer will equal $T$.

When talking about the probability of developing or not developing an infectious disease, a safe infective dose can be introduced to the analysis. By analogy with the safe dose of toxic chemicals $[16,17]$, the safe infective dose of a pathogen can be defined as follows: it is an infective dose at which, at a given antibody titer, the probability of developing the disease does not exceed a given probability (forced or psychologically acceptable).

A study [4] demonstrates that lgM and IgG titers measured in different individuals at the same point in time after exposure vary.

According to the existing theoretical concepts, the level of any antibody type at a specific point in time after exposure is a continuous random variable defined in the interval $[0, \infty]$ ) and characterized by a log-normal unconditional distribution inferred from equation (1). Then, the probability of a random variable (antibody titer) at a certain point in time after exposure being less than $T$ can be described as follows:

$$
F(\mathrm{~T})=0,5\left[1+\operatorname{erf}\left(\sqrt{\mathrm{k}_{\ln T} \ln \frac{T}{T_{\mathrm{e}}}}\right)\right]
$$

where $T_{e}$ is a distribution parameter for a random antibody titer: its median (half of the people at a given point in time after exposure will have antibody titers below $T_{e}$, the rest will have antibody titers above $\left.T_{e}\right) ; \sqrt{\mathrm{k}_{\mathrm{ln} T}}$ is a distribution parameter characterizing the range of antibody titers relative to the median (the lower $\sqrt{\mathrm{k}_{\mathrm{ln}} r}$, the wider the range relative to the median and, conversely, the higher $\sqrt{\mathrm{k}_{\ln T}}$, the narrower the range).

Distribution parameters for a random titer (6) can be defined from experimental data using a previously proposed method In some coordinate system, equation (6) represents a line [7]:

$$
\ln T=\ln T_{e}+\frac{1}{\sqrt{\mathrm{k}_{\ln T}}} \operatorname{argerf}[(2 F(T)-1],
$$

therefore, the method of least squares can be employed to estimate the unknown parameters of equation (7).

Table 1 shows grouped data on IgM titers on day 7 after exposure and IgG titers on day 33 after exposure (raw date were taken from [2]).

The results of the analysis based on the method of least squares of data from Table 1 for equation (7) are provided in Table 2; Fig. 2 shows the linear representation of these data.

Parameters of distribution for random antibody titers at other points in time after exposure were estimated in a similar fashion.

Satisfactory estimates obtained during the analysis support a theoretical conclusion that a random titer at a given point in time after exposure has a log-normal distribution.

Table 3 shows the results of the statistical analysis of lgM and IgG titers described by equation (7) which was conducted based on the method of least squares: distribution parameters for random $T_{e}$ and $\sqrt{\mathrm{k}_{\ln 7}}$ and statistical estimates of equation 
Table 1. Grouped data on $\lg M(n=11)$ and $\lg G(n=38)$ titers

\begin{tabular}{|c|c|c|c|c|c|}
\hline $\begin{array}{l}\text { Titer } T \text {, } \\
\text { AU } \times \mathrm{ml}^{-1}\end{array}$ & Number of cases with lower titers & Proportion of cases, $p$ & $2 p-1$ & $\operatorname{argerf}(2 p-1)$ & $\ln T$ \\
\hline \multicolumn{6}{|c|}{ IgM titers 7 days after exposure } \\
\hline 3,5 & 2 & 0.182 & -0.636 & -0.642 & 1.253 \\
\hline 12 & 5 & 0.455 & -0.091 & -0.081 & 2.485 \\
\hline 17 & 6 & 0.545 & 0.091 & 0.081 & 2.833 \\
\hline 59 & 9 & 0.818 & 0.636 & 0.642 & 4.078 \\
\hline 110 & 10 & 0.909 & 0.818 & 0.944 & 4.7 \\
\hline \multicolumn{6}{|c|}{$\lg \mathrm{G}$ titers 33 days after exposure } \\
\hline 67 & 3 & 0.079 & -0.842 & -0.999 & 4.205 \\
\hline 90 & 11 & 0.289 & -0.421 & -0.392 & 4.5 \\
\hline 114,2 & 18 & 0.474 & -0.053 & -0.047 & 4.738 \\
\hline 213 & 37 & 0.974 & 0.947 & 1.37 & 5.361 \\
\hline
\end{tabular}

Note: AU — arbitrary unit: the diagnostic system employed for quantitative analysis returned the results in its own units of measurement different from the international units of measurement.

parameters and the equation itself: Fisher's criterion, the correlation coefficient and mean squared errors for $\ln T_{e}$ and $\frac{1}{\sqrt{k_{\mathrm{an}} \mathrm{t}}}$.

The analysis of the dynamics of median antibody titers shows that the medians increase at first, reach a plateau level and then wane, falling almost to zero. Pharmacodynamically, this pattern can be easily explained within the confines of a one-compartment model [15]: after exposure, the organism starts to produce antibodies at a fixed rate; at the same time, the level of the produced antibodies decreases due to antibody elimination mechanisms, including metabolism, excretion of antibodies in the unchanged state, etc. At some point, when the rate of antibody production reaches the rate of their elimination, the dynamics of antibody titers will reach a plateau. Once the secretion of antibodies stops, their concentration in the blood will fall exponentially. Such qualitative dynamics of antibody titers allow us to arrive at the following differential equations.

In a time interval from 0 to the cessation of antibody production $(\tau)$, a change in the antibody titer $d T$ during an infinitely small time interval can be described as:

$$
d T=\frac{\mathrm{q}}{V_{k}} d t-\frac{\lambda}{V} T d t
$$

The solution to this equation takes the form of:

$$
T(t)=\frac{\mathrm{q}}{V_{k} \lambda}\left(1-e^{-\lambda t}\right),
$$

where $q$ is the rate of antibody production;

$V_{k}$ is the total blood volume in the organism, ml; day $^{-1}$.

$\lambda$ is the immunoglobulin elimination constant expressed as

Since $q$ equals 0 once the secretion of antibodies has stopped $(t>\tau)$, differential equation (8) will take the following form:

$$
d T=-\frac{\lambda}{V} T d t,
$$

The solution for equation (10) can be written as follows:

$T(t)=T(\tau) e^{-\lambda(t-\tau)}=\frac{q}{V_{k} \lambda}\left(1-e^{-\lambda \tau}\right) e^{-\lambda(t-\tau)}$.
Parameters of the model (8-11) were determined using the numeric method of least squares in Excel.

Fig. 3 shows the dynamics of median IgM titers and a theoretical curve described by equations (9) and (11).

The proposed mathematical model is useful for solving a range of applied problems, like computing the level and duration of immune protection following exposure to the infective dose.

Let us formulate the problem. There is a need to determine the level and duration of protective immunity after exposure to the infective dose $D$, given that the probability $p$ of developing the infectious disease does not exceed a given (forced) probability.

Based on the hazard factor law (4), by analogy with equation (5), let us find $I D_{50}$ at which the probability of the disease after exposure to the infective dose $D$ equals $p$ :

$$
I D_{50}^{*}(T)=D_{p} e^{-\frac{\operatorname{argerf}(2 p-1)}{\sqrt{\mathrm{k}_{\ln D}^{*}}}} .
$$

Having found $I D_{50}^{*}(T)$ let us now find, based on the bivariate log-normal distribution, the $\lg$ titer at which $I D_{50}^{*}(T)$ is:

$$
\ln T=\ln T_{50}+\mathrm{r}_{\ln D \ln T} \frac{\sqrt{\mathrm{k}_{\ln D}}}{\sqrt{\mathrm{k}_{\ln T}}} \ln \frac{D}{D_{50}} .
$$

Earlier in this paper, we showed that at a given point in time after exposure the IgG titer is a continuous stochastic variable which follows a log-normal distribution. So, there is some probability that this titer will be equal to or be higher than $T$ (the protective titer). Assuming there is a sufficiently high probability $p(T)$ that the antibody titer is equal to or higher than $T$, let us find a median titer which ensures this probability:

$$
T_{\mathrm{e}}=T e^{\frac{\operatorname{argerf}(1-2 p)}{\sqrt{k_{T}}}} .
$$

Table 2. Estimates of equation (7) parameters

\begin{tabular}{|c|c|c|c|c|c|c|c|}
\hline Antibody type & $\ln T e$ & $\sigma \ln T_{e}$ & $\sqrt{\mathrm{k}_{\ln \mathrm{T}}}$ & $\frac{\sigma}{\sqrt{\mathrm{k}_{\ln \mathrm{T}}}}$ & Correlation coefficient & Fisher's criterion & Significance of model \\
\hline $\lg \mathrm{M}$ & 2.658 & 0.007 & 0.459 & 0.012 & 1 & 34,260 & $<0.01$ \\
\hline $\lg \mathrm{S}$ & 4.709 & 0.021 & 2.051 & 0.024 & 0.998 & 406 & $<0.01$ \\
\hline
\end{tabular}


Table 3. Distribution parameters for a random antibody titer at a given point in time after exposure and statistical estimates

\begin{tabular}{|c|c|c|c|c|c|}
\hline \multirow[b]{2}{*}{ Time after exposure, days } & \multirow[b]{2}{*}{ Sample size, $N$} & \multirow[b]{2}{*}{ Median $T_{\mathrm{e}}$} & \multirow[b]{2}{*}{$\sqrt{\mathrm{k}_{\ln T}}$} & \multicolumn{2}{|c|}{ Statistical estimates for equation (7) } \\
\hline & & & & $\begin{array}{l}\text { Fisher's } \\
\text { criterion }\end{array}$ & Correlation coefficient \\
\hline \multicolumn{6}{|c|}{$\lg M$} \\
\hline 2 & 2 & 5.9 & 1.213 & - & - \\
\hline 5 & 9 & 6.9 & 0.27 & 6900 & 1 \\
\hline 8 & 13 & 11.8 & 0.566 & 44,500 & 1 \\
\hline 12 & 17 & 16.1 & 0.326 & 4200 & 1 \\
\hline 23 & 19 & 18 & 0.427 & 4600 & 1 \\
\hline 31 & 73 & 36.6 & 0.472 & 705 & 0.997 \\
\hline 42 & 87 & 32.7 & 0.473 & 4150 & 1 \\
\hline 49 & 50 & 27.6 & 0.621 & 2100 & 0.999 \\
\hline 58 & 26 & 20.2 & 0.403 & 9400 & 1 \\
\hline 66 & 35 & 14 & 0.617 & 560 & 0.997 \\
\hline 73 & 6 & 10.1 & 0.635 & 8650 & 1 \\
\hline \multicolumn{6}{|c|}{$\lg G$} \\
\hline 6 & 18 & 19.6 & 0.308 & 33 & 0.897 \\
\hline 12 & 17 & 42.6 & 0.275 & 17 & 0.968 \\
\hline 28 & 19 & 72.2 & 0.621 & 38 & 0.951 \\
\hline 42 & 88 & 118.2 & 1.77 & 50 & 0.936 \\
\hline 64 & 23 & 92.9 & 1.283 & 40 & 0.953 \\
\hline 70 & 27 & 74 & 0.805 & 41 & 0.955 \\
\hline 79 & 26 & 66.2 & 1.582 & 51 & 0.981 \\
\hline
\end{tabular}

Then the probability of an individual not developing the disease after exposure to the infective dose $D$ is the product of multiplication of 2 probabilities: the probability $p(T)$ that the IgG titer will be higher than $T$ and the probability $1-p(D)$ that the infected person will not develop the disease after exposure to the infective dose, i.e.:

$$
T_{\mathrm{e}}=T e^{\frac{\operatorname{argerf}(1-2 p)}{\sqrt{k_{T}}}}
$$

It follows from this solution that for humans with a given antibody titer, the level of protection (protective immunity) is linked to the probability of developing or not developing a disease disease following exposure to some infective dose $D$.

Now, let us find the duration of protective immunity, i.e. the time interval thoughout which the lgG titer equals to or is above a given value. This is consistent with the median Te titer being equal to or above the value determined by equation (14).

By equaling the median titer $T_{e}$, determined by (14) to its dynamics over time, we will get:

$$
\text { -at } t<\tau
$$

$$
T_{e}(t)=\frac{\mathrm{q}}{V_{k} \lambda}\left(1-e^{-\lambda t}\right)
$$

IgM titers 7 days after exposure

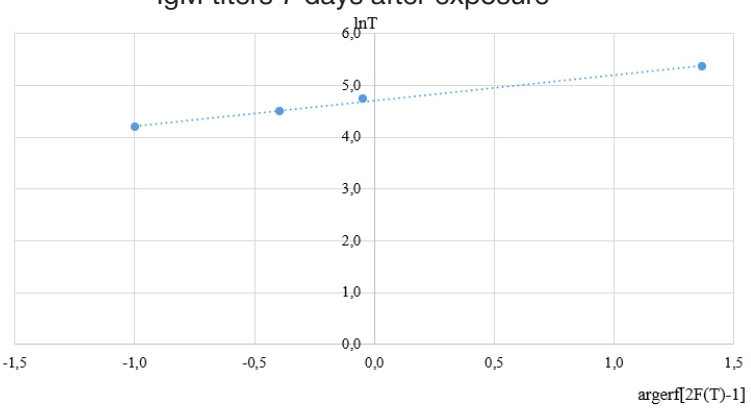

$$
\text { -at } t>\tau
$$

$$
T_{e}(t)=T(\tau) e^{-\lambda(t-\tau)}=\frac{q}{V_{k} \lambda}\left(1-e^{-\lambda \tau}\right) e^{-\lambda(t-\tau)} .
$$

The onset time $t_{0}$ and the termination time $t t$ are inferred from equations (16) and (17). Those are time points after exposure at the beginning and at the end of the time interval throughout which the median titer is maintained at the level equaling to or higher than a given level determined by expressions (16) and (17):

$$
\begin{aligned}
t_{\mathrm{H}} & =-\frac{\ln \left[1-\frac{V}{\mathrm{q} \lambda} T_{e}(t)\right]}{\lambda}, \\
t_{\mathrm{K}} & =\tau-\frac{\ln \frac{T_{e}(t)}{T_{e}(\tau)}}{\lambda} .
\end{aligned}
$$

The graphic representation of these time values is provided in Fig. 4.

Considering the abovesaid, the duration of protective immunity can be calculated using the formula:

$$
\Delta t=t_{\mathrm{K}}-t_{\mathrm{H}}=\tau-\frac{\ln \frac{T_{e}(t)}{T_{e}(\tau)}}{\lambda}+\frac{\ln \left[1-\frac{V}{\mathrm{q} \lambda} T_{e}(t)\right]}{\lambda} .
$$

$\lg \mathrm{G}$ titers 33 days after exposure

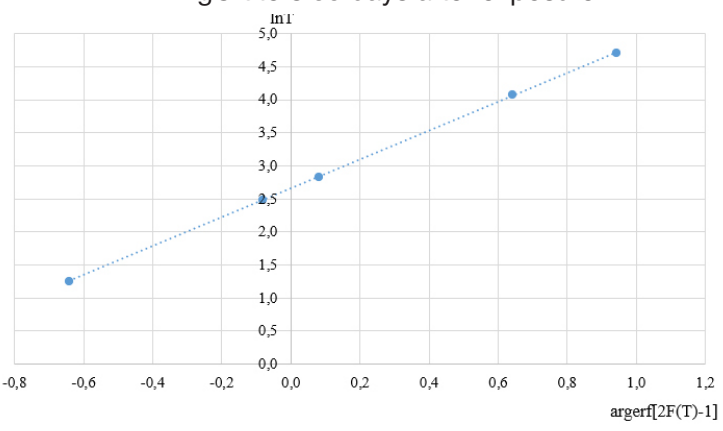

Fig. 2. The linear representation of the distribution law for random IgM and IgG titers 
A

$T e(t) \lg M$

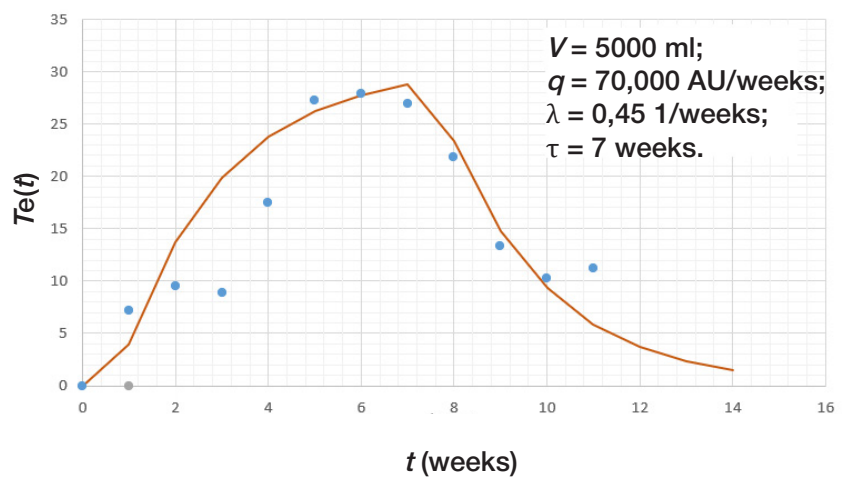

Fig. 3. The dynamics of median IgM (A) and IgG (B) titers over time

These solutions work for different types of antibodies produced after exposure to a pathogen or after immunization.

In the most general case, parameters of the proposed models depend on a number of factors like sex, age (children, adults, individuals of advanced age), general health (seemingly healthy individuals, patients with chronic conditions, etc.), medical history (a past history of the disease or immunization, immunized patient with or without a past history of infection).

In order to quantitatively determine the level and duration of protective immunity, we need to know 5 quantitative characteristics of virulence for each of homogenous population groups in a system of 2 random variables: the infective dose and the antibody titer at which the disease develops, as well as to describe the dynamics of antibody titers after infection or immunization.

\section{DISCUSSION}

As a rule, the literature provides only qualitative or semiquantitative estimates. Often, there is no characterization of antibody titers at some point in time after exposure: positivity coefficients are described instead. Usually, no theoretical rationale for antibody titer dynamics is provided [2, 3, 8, 18, 19]. The dynamics of antibody titers are different for different antibody types. For example, the rates of production of IgM and IgG antibodies to the $N$-protein and RBD are not the same. IgM antibodies to the $N$ protein are produced at a
B

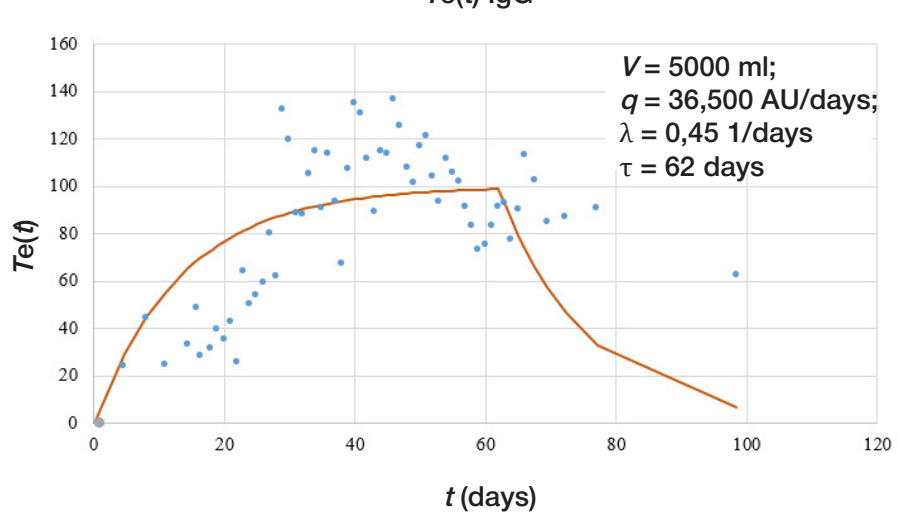

faster rate and have a high peak, whereas IgG-antibodies for the same protein are produced at a slower rate and do not reach high concentrations. By contrast, IgG antibodies to $R B D$ grow rapidly, whereas IgM antibodies to $R B D$ are produced at a slower rate $[18,19]$. Most of the existing ELISA kits for measuring antibodies to SARS-CoV-2 target the S-protein, its $R B D$ fragment and the $N$ protein.

\section{CONCLUSIONS}

A few mathematical models were developed in the course of this study: 1) the hazard factor law, which models the probability of developing COVID-19 after exposure to the infective dose of SaRS-CoV-2 by an individual who already has some lgG; 2) the model of antibody titer dynamics in a human organism based on the averaged rate of antibody production over time - and the rate of simultaneous antibody elimination by all bodily mechanisms; 3) using these 2 models, a method for measuring protective immunity and its duration was proposed. Similar solutions can be applied to immunized populations. In order to obtain hard numbers reflecting the level and duration of protective immunity, parameters of the proposed models need to be experimentally identified first. This will help to bridge the existing gap associated with the absence of one of the basic vaccine characteristics: developers of SARS-CoV-2 vaccines do not know what antibody levels and immunity duration are protective against the disease.

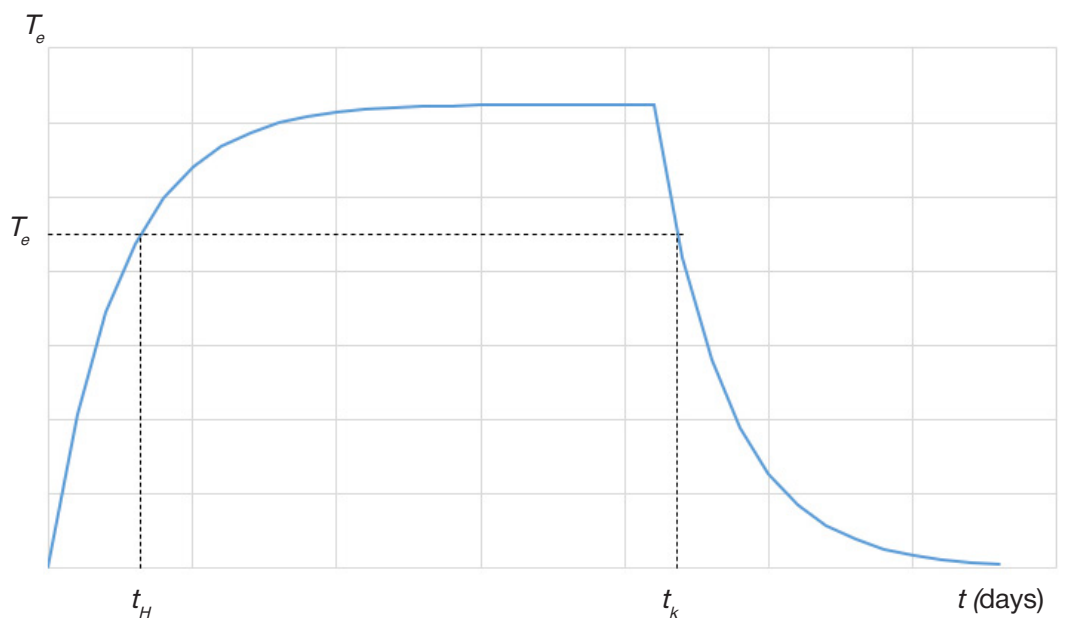

Fig. 4. The graphic representation of the solution to the problem of protective immunity duration 
1. Ye Q, Wang B, Mao J, Fu J, Shang S, Shu Q, et al. Epidemiological analysis of COVID-19 and practical experience from China. J Med Virol. 2020 Jul; 92 (7): 755-69. DOI: 10.1002/jmv.25813. Epub 2020 Apr 10. PMID: 32237160; PMCID: PMC7228220.

2. Li K, Huang B, Wu M, et al. Dynamic changes in anti-SARSCoV-2 antibodies during SARS-CoV-2 infection and recovery from COVID-19. Nat Commun 11, 6044 (2020). Available from: https://doi.org/10.1038/s41467-020-19943-y.

3. Sun B, Feng Y, Mo X, Zheng P, Wang Q, Li P, et al. Kinetics of SARS-CoV-2 specific IgM and IgG responses in COVID-19 patients. Emerg Microbes Infect. 2020 Dec; 9 (1): 940-8. DOI: 10.1080/22221751.2020.1762515. PMID: 32357808; PMCID: PMC7273175.

4. Karmishin AM, Borisevich IV, Kruglov AA, Nosov NYu, Postupailo VB, Zhigarlovskij BA, i dr. Teoreticheskie aspekty modelirovanija jepidemii COVID-19. WV RHB zashhity. 2020; 4 (90): 73-88. Russian.

5. Postupajlo VB, Karmishin AM, Nosov NYu, Zhigarlovskij BA; zajavitel' i pravoobladatel'. Sposob opredelenija kolichestvennyh harakteristik processa inficirovanija naselenija SARS-CoV-2 v razlichnyh stranah. Svidetel'stvo o gosudarstvennoj registracii bazy dannyh \# 2021620762 Rossijskaja Federacija; zjavl. 05.04.2021; gosregistracija 16.04.2021. Russian.

6. Karmishin AM., Gumenjuk VI, Makarov ML. Teoreticheskie aspekty obosnovanija kolichestvennyh pokazatelej opasnosti avarij potencial'no opasnyh promyshlennyh ob"ektov. Problemy bezopasnosti i chrezvychajnyh situacii 2019; 2: 51-66. Russian.

7. Karmishin AM, Borisevich IV, Skvorcova VI, Gorjaev AA, Judin SM. Verojatnost' vozniknovenija infekcionnogo zabolevanija cheloveka pri jepidemii. Medicina jekstremal'nyh situacij. 2021; 1: 5-11. DOI: 10.47183/mes.2021.007. Russian.

8. Lei Q, Li Y, Hou HY, et al. Antibody dynamics to SARS-CoV-2 in asymptomaticCOVID-19infections. Allergy. 2021; 76: 551-61. Aailable from: https://doi.org/10.1111/all.14622.

9. Dronina AM, Guzovskaja TS, Severinchik IV, Bandackaja MI, Chistenko GN. Osnovy immunoprofilaktiki: uchebno-metodicheskoe posobie. Minsk: BMGU, 2019; 138 s. Russian.

10. Instrukcija po medicinskomu primeneniju lekarstvennogo preparata Gam-KOVID-Vak. Kombinirovannaja vektornaja vakcina dlja profilaktiki koronavirusnoj infekcii, vyzyvaemoj virusom SARS-CoV-2. Aailable from: https://grls.rosminzdrav. ru/Grls_View_v2.aspx?routingGuid=44bfoff3-f94e-4c42-954ea4c53811576c\&t. (Ssylka aktivna na 22 aprelja 2021). Russian.

11. Instrukcija po medicinskomu primeneniju lekarstvennogo preparata "JepiVakKorona». Vakcina na osnove peptidnyh

\section{Литература}

1. Ye Q, Wang B, Mao J, Fu J, Shang S, Shu Q, et al. Epidemiological analysis of COVID-19 and practical experience from China. J Med Virol. 2020 Jul; 92 (7): 755-69. DOI: 10.1002/jmv.25813. Epub 2020 Apr 10. PMID: 32237160; PMCID: PMC7228220.

2. Li K, Huang B, Wu M, et al. Dynamic changes in anti-SARSCoV-2 antibodies during SARS-CoV-2 infection and recovery from COVID-19. Nat Commun 11, 6044 (2020). Available from: https://doi.org/10.1038/s41467-020-19943-y.

3. Sun B, Feng $Y$, Mo X, Zheng P, Wang Q, Li P, et al. Kinetics of SARS-CoV-2 specific IgM and IgG responses in COVID-19 patients. Emerg Microbes Infect. 2020 Dec; 9 (1): 940-8. DOI: 10.1080/22221751.2020.1762515. PMID: 32357808; PMCID: PMC7273175.

4. Кармишин А. М., Борисевич И. В., Круглов А. А., Носов Н. Ю., Поступайло В. Б., Жигарловский Б. А. и др. Теоретические аспекты моделирования эпидемии COVID-19. BВ РХБ защиты. 2020; 4 (90): 73-88.

5. Поступайло В. Б., КармишинА. М., Носов Н. Ю., ЖигарловскийБ. А.; заявитель и правообладатель. Способ определения количественных характеристик процесса инфицирования населения SARS-CoV-2 в различных странах. Свидетельство о государственной регистрации базы данных № 2021620762 antigenov dlja profilaktiki COVID-19. Dostupno po ssylke: https:// grls.rosminzdrav.ru/Grls_View_v2.aspx?routingGuid=fa7efa734f93-4e05-b467-03998160616d\&t. (Ssylka aktivna na 22 aprelja 2021). Russian

12. REG 174 information for UK healthcare professionals. Aailable from: https://assets.publishing.service.gov.uk/government/ uploads/system/uploads/attachment_data/file/978194/uk-HCPcovid-19-vaccine-astrazeneca-reg174_proposed_14_Apr_2021. pdf. (Ссылка активна на 22 апреля 2021).

13. Fact sheet for recipients and caregivers emergency use authorization (EUA) of the Moderna covid-19 vaccine to prevent coronavirus disease 2019 (COVID-19) in individuals 18 years of age and older. Aailable from: https://www.modernatx.com/ covid19vaccine-eua/eua-fact-sheet-recipients.pdf. (Ссылка активна на 22 апреля 2021).

14. Fact sheet for recipients and caregivers emergency use authorization (EUA) of the Pfizer-BioNTech COVID-19 Vaccine to prevent Coronavirus Disease 2019 (COVID-19) in individuals 16 years of age and older. Aailable from: https://www.fda.gov/ media/144414/download. (Ссылка активна на 22 апреля 2021).

15. Karmishin AM, Kireev VA, Berezin Gl, Afanasev RV. Matematicheskie metody farmakologii, toksikologii i radiobiologii. M.: OOO «APR», 2011; 330 s. Russian.

16. Karmishin AM. K voprosu o bezopasnoj doze toksichnyh himicheskih veshhestv. V sbornike: V. R. Rembovskij, redaktor. Materialy Vserossijskoj nauchno-prakticheskoj konferencii, posvjashhennoj 55-letiju FGUP «NII GPJeCh» FMBA Rossii, 17 fevralja 2017 g., g. Sankt-Peterburg. SPb.: Izd. Politehn. un-ta, 2017; s. 64-66. Russian.

17. Karmishin AM, Nosov NYu, Zhigarlovskij BA, Postupajlo VB. Bezopasnaja doza toksichnyh himicheskih veshhestv. $\vee$ sbornike: Materialy I Nacional'nogo kongressa s mezhdunarodnym uchastiem po jekologii cheloveka, gigiene i medicine okruzhajushhej sredy «SYSINSKIE ChTENIJa - 2020» Moskva, 19-20 nojabrja 2020 g. M.: FGBU «CSP» FMBA Rossii, 2020; s. 168-72. Russian.

18. Kombarova SYu, Aleshkin AV, Novikova LI, Bochkareva SS, Karpov OYe, Pulin AA, i dr. Dinamika antitel k razlichnym antigenam koronavirusa SARS-CoV-2 u bol'nyh s podtverzhdennoj infekciej Covid-19. 2020. COVID19-PREPRINTS.MICROBE.RU. Dostupno po ssylke: https://doi.org/10.21055/preprints-3111756. Russian.

19. Popova AYu, Ezhlova EB, Melnikova AA, Andreeva EE, Kombarova SYu, Ljalina LV, i dr. Kollektivnyj immunitet k SARS-CoV-2 zhitelej Moskvy v jepidemicheskij period COVID-19. Infekcionnye bolezni. 2020; 18 (4): 8-16. DOl: 10.20953/1729-9225-2020-4-8-16. Russian.

Российская Федерация; зявл. 05.04.2021; госрегистрация 16.04.2021.

6. Кармишин А. М., Гуменюк В. И., Макаров М. Л. Теоретические аспекты обоснования количественных показателей опасности аварий потенциально опасных промышленных объектов. Проблемы безопасности и чрезвычайных ситуаций 2019; 2: 51-66.

7. Кармишин А. М., Борисевич И. В., Скворцова В. И., Горяев А. А. Юдин С. М. Вероятность возникновения инфекционного заболевания человека при эпидемии. Медицина экстремальных ситуаций. 2021; 1: 5-11. DOI: 10.47183/ mes.2021.007.

8. Lei Q, Li Y, Hou HY, et al. Antibody dynamics to SARS-CoV-2 in asymptomaticCOVID-19infections. Allergy. 2021; 76: 551-61. Aailable from: https://doi.org/10.1111/all.14622.

9. Дронина А. М., Гузовская Т. С., Северинчик И. В., Бандацкая М. И., Чистенко Г. Н. Основы иммунопрофилактики: учебнометодическое пособие. Минск: БМГУ, 2019; 138 с.

10. Инструкция по медицинскому применению лекарственного препарата Гам-КОВИД-Вак. Комбинированная векторная вакцина для профилактики коронавирусной инфекции, вызываемой вирусом SARS-CoV-2. Aailable from: https://grls. 
rosminzdrav.ru/Grls_View_v2. aspx? routingGuid=44bfoff3-f94e4c42-954e-a4c53811576c\&t. (Ссылка активна на 22 апреля 2021).

11. Инструкция по медицинскому применению лекарственного препарата «ЭпиВакКорона». Вакцина на основе пептидных антигенов для просилактики COVID-19. Доступно по: https:// grls.rosminzdrav.ru/Grls_View_v2.aspx?routingGuid=fa7efa734f93-4e05-b467-03998160616d\&t. (Ссылка активна на 22 апреля 2021).

12. REG 174 information for UK healthcare professionals. Aailable from: https://assets.publishing.service.gov.uk/government/ uploads/system/uploads/attachment_data/file/978194/uk-HCPcovid-19-vaccine-astrazeneca-reg174_proposed_14_Apr_2021. pdf. (Ссылка активна на 22 апреля 2021).

13. Fact sheet for recipients and caregivers emergency use authorization (EUA) of the Moderna covid-19 vaccine to prevent coronavirus disease 2019 (COVID-19) in individuals 18 years of age and older. Aailable from: https://www.modernatx.com/ covid19vaccine-eua/eua-fact-sheet-recipients.pdf. (Ссылка активна на 22 апреля 2021).

14. Fact sheet for recipients and caregivers emergency use authorization (EUA) of the Pfizer-BioNTech COVID-19 Vaccine to prevent Coronavirus Disease 2019 (COVID-19) in individuals 16 years of age and older. Aailable from: https://www.fda.gov/ media/144414/download. (Ссылка активна на 22 апреля 2021).

15. Кармишин А. М., Киреев В. А., Березин Г. И., Афанасьев Р. В.
Математические методы фармакологии, токсикологии и радиобиологии. М.: ООО «АПР», 2011; 330 с.

16. Кармишин А. М. К вопросу о безопасной дозе токсичных химических веществ. В сборнике: В. Р. Рембовский, редактор. Материалы Всероссийской научно-практической конференции, посвященной 55-летию ФГУП «НИИ ГПЭЧ» ФМБА России, 17 февраля 2017 г., г. Санкт-Петербург. СПб.: Изд. Политехн. ун-та, 2017; с. 64-66.

17. Кармишин А. М., Носов Н. Ю., Жигарловский Б. А., Поступайло В. Б. Безопасная доза токсичных химических веществ. В сборнике: Материалы I Национального конгресса с международным участием по экологии человека, гигиене И медицине окружающей среды «СЫСИНСКИЕ ЧТЕНИЯ 2020» Москва, 19-20 ноября 2020 г. М.: ФГБУ «ЦСП» ФМБА России, 2020; с. 168-72.

18. Комбарова С. Ю., Алешкин А. В., Новикова Л. И., Бочкарева С. С., Карпов О. Э., Пулин А. А., и др. Динамика антител к различным антигенам коронавируса SARS-CoV-2 у больных с подтвержденной инфекцией Covid-19. 2020. COVID19PREPRINTS.MICROBE.RU. Доступно по ссылке: https://doi. org/10.21055/preprints-3111756.

19. Попова А. Ю., Ежлова Е. Б., Мельникова А. А., Андреева Е. Е., Комбарова С. Ю., Лялина Л. В., и др. Коллективный иммунитет к SARS-CoV-2 жителей Москвы в эпидемический период COVID-19. Инфекционные болезни. 2020; 18 (4): 8-16. DOI: 10.20953/1729-9225-2020-4-8-16. 


\title{
PEDIATRIC INFLAMMATORY MULTISYSTEM SYNDROME TEMPORALLY ASSOCIATED WITH SARS-COV-2 INFECTION
}

\author{
Lobzin YuV ${ }^{1,2,4}$, Uskov AN ${ }^{1}$, Skripchenko NV ${ }^{1,3}$, Vilnits $A A^{1,3}$, Bekhtereva MK $^{1,3}$, Babachenko IV ${ }^{1,3}$ \\ ${ }_{1}^{1}$ Pediatric Research and Clinical Center for Infectious Diseases of FMBA, Saint Petersburg, Russia \\ ${ }^{2}$ Mechnikov North-West State Medical University, Saint Petersburg, Russia \\ ${ }^{3}$ Saint Petersburg State Pediatric Medical University, Saint Petersburg, Russia \\ ${ }^{4}$ Kirov Military Medical Academy, Saint Petersburg, Russia
}

\begin{abstract}
Despite the low incidence, low mortality and relatively mild symptoms of COVID-19 in children, there has been a rise in pediatric patients who develop a condition resembling Kawasaki disease after COVID-19 or contact with individuals infected with SARS-CoV-2. This condition is known as the pediatric inflammatory multisystem syndrome temporally associated with SARS-CoV-2 infection (PIMS-TS). This review introduces the reader to the hypotheses of PIMS-TS pathogenesis, provides information about its diagnosis and treatment, presents clinical and laboratory data and describes treatments strategies used in children and adolescents hospitalized to the intensive care unit of the Pediatric Research and Clinical Center for Infectious Diseases. Besides, the review outlines the main diagnostic and prognostic challenges of PIMS-TS.
\end{abstract}

Keywords: multisystem inflammatory syndrome, coronavirus infection, COVID-19, SARS-CoV-2, children

Author contribution: Lobzin YuV, Uskov AN, Skripchenko NV — study concept and design; Vilnits AA, Bekhtereva MK, Babachenko IV — data acquisition and processing, statistical analysis, manuscript preparation; Skripchenko NV — editing.

Correspondence should be addressed: Alla A. Vilnits

Professora Popova, 9, Saint Petersburg, 197022; vilnitz@mail.ru

Received: 07.06.2021 Accepted: 21.06.2021 Published online: 26.06.2021

DOI: $10.47183 /$ mes.2021.017

\section{COVID-19-АССОЦИИРОВАННЫЙ ПЕДИАТРИЧЕСКИЙ МУЛЬТИСИСТЕМНЫЙ ВОСПАЛИТЕЛЬНЫЙ СИНДРОМ}

\author{
Ю. В. Лобзин ${ }^{1,2,4}$, А. Н. Усков ${ }^{1}$, Н. В. Скрипченко ${ }^{1,3}$, А. А. Вильниц ${ }^{1,3}$, М. К. Бехтерева ${ }^{1,3}$, И. В. Бабаченко \\ 1 Детский научно-клинический центр инфекционных болезней Федерального медико-биологического агентства, Санкт-Петербург, Россия \\ ${ }^{2}$ Северо-Западный государственный медицинский университет имени И. И. Мечникова, Санкт-Петербург, Россия \\ ${ }^{3}$ Санкт-Петербургский государственный педиатрический медицинский университет, Санкт-Петербург, Россия \\ ${ }^{4}$ Военно-медицинская академия имени С. М. Кирова, Санкт-Петербург, Россия
}

\begin{abstract}
Несмотря на невысокую заболеваемость и летальность, относительно легкое течение COVID-19 в педиатрической популяции, в последнее время у детей после перенесенной коронавирусной инфекции или контакта с инфицированным выросло число случаев развития состояния, по клинической картине схожего с болезнью Кавасаки, которое получило название педиатрический мультисистемный воспалительный синдром, ассоциированный с COVID-19 (ПМВC). В обзоре представлены современные взгляды на возможный патогенез данного состояния, диагностику и лечение, а также данные по клинико-инструментальной картине и тактике ведения ПМВС у детей и подростков, госпитализированных в отделение интенсивной терапии Детского научно-клинического центра инфекционных болезней. Изложены основные проблемы своевременной диагностики и прогнозирования исходов ПМВС у детей.
\end{abstract}

Ключевые слова: воспалительный мультисистемный синдром, коронавирусная инфекция, COVID-19, SARS-CoV-2, дети

Вклад авторов: Ю. В. Лобзин, А. Н. Усков, Н. В. Скрипченко - концепция и дизайн исследования; А. А. Вильниц, М. К. Бехтерева, И. В. Бабаченко сбор и обработка материала, статистическая обработка, написание текста; Н. В. Скрипченко - редактирование.

$\triangle$ Для корреспонденции: Алла Ароновна Вильниц

ул. профессора Попова, д. 9, г. Санкт-Петербург, 197022 ; vilnitz@mail.ru

Статья получена: 07.06.2021 Статья принята к печати: 21.06.2021 Опубликована онлайн: 26.06.2021

DOI: $10.47183 /$ mes.2021.017

The pandemic of the novel coronavirus infection (COVID-19) is still raging; so far, over 130 million confirmed cases and 2.8 million death from COVID-19 have been reported [1]. According to different sources, children make up approximately $2-5 \%$ of the affected patients [2-4]. Across Russia, the prevalence of COVID-19 in children is 1-8.6\% [5], and in most cases the disease is asymptomatic or mild. According to the US Centers for Disease Control and Prevention (CDC), pediatric mortality from COVID-19 is less than $0.1 \%$, while the hospitalization rate is about $2.5 \%$. Of all children and adolescents hospitalized for COVID-19, only 0.8\% required intensive care [6]. Severe comorbidities were the primary cause of admission to intensive care units.

However, in April 2020 reports started to emerge in US, UK $[7,8]$ and then other countries about the growing number of children and adolescents hospitalized to intensive care units with symptoms resembling Kawasaki disease, signs of damage to multiple organs, the clinical picture of toxic or septic shock, and myocarditis with subsequent cardiogenic shock. In all those cases, the patients had a history of contact with individuals infected with SARS-CoV-2 2-6 weeks prior to the onset of symptoms or had SARS-CoV-2-specific antibodies. Notably, the symptoms of acute COVID-19 in most of those children admitted to intensive care units were very mild and their nasopharyngeal swabs collected at the time of admission for PCR tests were negative for SARS-CoV-2. In Europe, their condition was named the pediatric inflammatory multisystem syndrome temporally associated with SARS-CoV-2 infection (PIMS-TS). In the USA, the condition is referred to as multisystem inflammatory syndrome in children (MIS-C). 


\section{Hypothetical mechanisms of PIMS-TS}

The pathogenesis of PIMS-TS is a subject of ongoing debate. There is a hypothesis that the key implicated factor is delayed interferon production at the onset of SARS-CoV-2 infection, which results in severe disease and significant damage to the lungs in older patients at week 2 after infection. In children, PIMSTS appears to develop after the virus is no longer detected on naso- and oropharyngeal mucosa by laboratory tests $[9,10]$. According to another hypothesis, the underlying mechanism of PIMS-TS is similar to that of Dengue fever and relies on the antibody-dependent enhancement of viral replication via phagocytosis and death of immune cells, which, in turn, causes septic shock and multiorgan failure [11]. The literature describes a clinical case of a child with PIMS-TS who died of heart failure; the post-mortem pathomorphological examination detected the presence of the virus in the patient's cardiac muscle tissue, suggesting that virus-mediated tissue injury may have been a potential contributor to PIMS-TS [12]. Macrophage activation syndrome has a very similar pathogenesis; it is observed in children with systemic juvenile idiopathic arthritis and COVID19-related hemophagocytic lymphohistiocytosis [13-15]. Similar to Kawasaki disease, autoantibodies are suspected to play a role in the pathogenesis of PIMS-TS. It is reported that autoantibody levels in infected children with PIMS-TS are higher than in healthy children, children with acute COVID-19 and those with Kawasaki disease. Autoantibodies participating in lymphocyte activation, intracellular signaling and cardiogenesis are superexpressed in PIMS-TS patients. Some autoantibodies to various types of casein kinase are only seen it patients with PIMS-TS. The involvement of multiple organs and tissues in PIMS-TS might be explained by the ubiquity of potential targets for such autoantibodies [16]. According to recent reports, patients with PIMS-TS have elevated levels of IL18 and IL6, increased lymphocytic and myeloid chemotaxis and mucosal immune dysregulation [17]. Hyperinflammation in patients with PIMS-TS differs from that associated with Kawasaki disease, in which IL17A plays the key role; it is also different from acute COVID-19 in children and cytokine storm in adults [16].

\section{Clinical and laboratory criteria for PIMS-TS}

According to systematic reviews [18-22], clinical manifestations of PIMS-TS include a persistent (at least 5-day-long) fever observed in $97-100 \%$ of cases, skin symptoms (rashes in 36$81 \%$ of cases), mucosal involvement (conjunctivitis and cheilitis in $30-94 \%$ of cases), edema in feet and hands (16-68\%), and mild lymphadenopathy (10-60\%). Gastrointestinal symptoms are reported in $84-87 \%$ of cases, setting in at the earliest stages of the disease, and manifest as pain in the stomach, vomiting and diarrhea. Respiratory systems (cough and rhinorrhea) are less common (12-34\%). Cardiovascular involvement is seen in $25 \%$ of patients with PIMS-TS; according to ultrasonography data, some patients develop coronary artery damage without myocarditis and acute coronary syndrome, which distinguishes PIMS-TS from Kawasaki disease: in Kawasaki disease, the risk of arterial damage is inversely proportional to age and is observed in infants during the first year of life, whereas PIMSTS develops in older children and adolescents: according to different literature sources, the median age for this disease is $8-9$ years $[19,20,23,24]$. In some cases, damage to the cardiovascular system manifests as acute myocardial injury accompanied by cardiogenic and vasodilatory shock that requires vasopressor and inotropic therapy, and by elevated cardiac myocytolysis markers [21, 22, 25]. Importantly, 26-56\% of children with PIMS-TS have neurological symptoms, like headache, mental confusion or meningeal symptoms [19].

Laboratory tests show that patients with PIMS-TS have significantly elevated proinflammatory markers (C-reactive protein, procalcitonin, ferritin, ESR, IL6, fibrinogen). Markers of myocardial injury (brain natriuretic propeptide, N-terminal pro-brain natriuretic peptide, troponin) can be elevated in such patients, too. Most patients with PIMS-TS have heightened D-dimer, neutrophilia, lymphocytopenia and low albumin. Thrombocytopenia is another PIMS-TS feature distinguishing it from classic Kawasaki disease. ECG may be suggestive of repolarization abnormalities, focal ischemic changes, conduction anomalies and arrhythmias. In 60\% of PIMS-TS cases, echocardiography reveals signs of myocarditis, including reduced left ventricular ejection fraction $(\leq 50 \%)$ in half of the cases, pericardial effusion in 34\% of cases and coronary artery dilatation in $23 \%$ of cases [19]. Abdominal ultrasound scans may be suggestive of hepatosplenomegaly, lymphadenopathy, ascites, colitis or ileitis $[6,26]$. Chest X-ray and CT features may include ground glass opacities in the lungs, changes to the interstitium, possibly associated with insufficient blood supply, acute respiratory distress syndrome and coagulation disorders.

The absence of confirmed involvement of a causative agent other than SARS-CoV-2 in the symptoms listed above is a crucial criterion for establishing the diagnosis of PIMS-TS. The differential diagnosis should include sepsis, toxic shock caused by streptococci or staphylococci, and enterovirus-associated myocardial injury, Kawasaki disease, macrophage activation syndrome, hemophagocytic lymphohistiocytosis, and the onset of a systemic connective tissue disease [27].

$\mathrm{CDC}$ and $\mathrm{WHO}$ have proposed diagnostic approaches to PIMS-TS accounting for the results of clinical and laboratory tests and the past medical history of the patient. The most elaborate diagnostic and management guidelines for PIMS-TS have been put forward by the consensus of UK experts (Table).

The diagnosis of PIMS-TS is hampered at the prehospital stage. The onset of PIMS-TS shares similarities with early symptoms of other infectious diseases. As a result, patients with PIMS-TS are often referred to the departments of infectious diseases for intestinal, neurological or other respiratory infections. Considering the high risk of life-threatening conditions in patients with PIMS-TS, it is crucial to timely identify children with PIMS-TS in order to initiate immediate treatment and minimize poor outcomes.

\section{PIMS-TS in Saint Petersburg}

At present, the prevalence of PIMS-TS in Russia in general and Saint Petersburg in particular is unknown because the disease is often classified to ICD codes used for other conditions. However, it is still possible to conduct a preliminary analysis of admissions for COVID-19-associated PIMS-TS to intensive care units of Saint Petersburg hospitals for infectious diseases during the epidemic.

The first pediatric admissions with clinical and laboratory signs of PIMS-TS were reported in April and May, 2020. The first patients with PIMS-TS admitted to the City Clinical Hospital for Children № 5 (the main inpatient care facility that admits pediatric patients with COVID-19) were reported in June 2020, 2 months after the Hospital began to admit adult patients with acute COVID-19. In Saint-Petersburg, the surge in PIMS-TS cases occurred in the fall of 2020. From November 2020 through January 2021, the City Clinical Hospital for Children № 5 and the Saint Petersburg State Pediatric Medical University 
Table. Diagnostic guidelines for PIMS-TS

\begin{tabular}{|c|c|c|}
\hline \multicolumn{2}{|c|}{ Criteria } & Parameters \\
\hline \multirow{11}{*}{\multicolumn{2}{|c|}{ Clinical }} & Age $<21$ years \\
\hline & & + body temperature above $38^{\circ} \mathrm{C}$ for $\geq 1$ day \\
\hline & & + hospitalization required \\
\hline & & Plus $\geq$ one of the following: \\
\hline & & Low blood pressure or signs of cardiogenic/vasodilatory shock \\
\hline & & $\begin{array}{l}\text { Signs of serious cardiac injury (signs of myocarditis, pericarditis, valvulitis, elevated troponin/natriuretic peptide, } \\
\text { coronary anomalies, etc.) }\end{array}$ \\
\hline & & Or \\
\hline & & Plus $\geq$ two of the following: \\
\hline & & Maculopapular eruption \\
\hline & & Bilateral non-purulent conjunctivitis \\
\hline & & Signs of oral mucosa or limb skin involvement \\
\hline & & + Two or more of the following laboratory parameters: \\
\hline & Standard & $\begin{array}{l}\text { Neutrophilia, lymphopenia, thrombocytopenia, hypoalbumenia, elevated CRP, ESR, fibrinogen, ferritin, D-dimer, IL6, } \\
\text { OR elevated procalcitonin }\end{array}$ \\
\hline 茪 & & One of following SARS-CoV-2 tests: \\
\hline$\frac{0}{\pi}$ & Virologic/ & Positive PCR test at the time of presentation or within 4 weeks prior to presentation \\
\hline & & Presence of IgM or IgG antibodies \\
\hline & & + One or more factors within 6 weeks prior to onset of symptoms: \\
\hline & & Close contact with infected person \\
\hline Epid & ological & $\begin{array}{l}\text { Close contact with patient with COVID-19 symptoms who had a history of contact with another individual with COVID-19 } \\
\text { confirmed by laboratory tests }\end{array}$ \\
\hline & & Travelling to or living in areas with COVID-19 spread \\
\hline of $c$ & $\begin{array}{l}\text { ition } \\
\text { al case }\end{array}$ & $\begin{array}{l}\text { Confirmed (from clinical, laboratory and virologic/serologic tests) } \\
\text { Possible (from clinical, standard laboratory, and epidemiological data) }\end{array}$ \\
\hline
\end{tabular}

admitted 25 and 17 children, respectively, meeting the criteria for PIMS-TS [28].

During the preCOVID era, the incidence of Kawasaki disease in Saint Petersburg was less than 1.6 per 100,000 children under 18 years; in November and December, it increased to 5.2 per 100,000 children, i.e. it could be estimated as 20 cases per 100,000 pediatric population over 12 months. From November through January, there was a 10-15-fold increase in PIMS-TS cases; its future dynamics are difficult to predict.

According to the Pediatric Research and Clinical Center for Infectious Diseases, the number of hospitalizations for Kawasaki disease disguised as a gastrointestinal infection did not exceed 3-5 before 2018. But between January 2018 and December, 2020, as many as 30 children were hospitalized (10-12 children per year) with Kawasaki symptoms. In most cases, the patients were boys under 5 years who met the 2006 EULAR/PreS consensus criteria for vasculitides [29, 30].

Saint-Petersburg reported the first patients with PIMS-TS in April and May 2020. A few unusual Kawasaki cases were detected retrospectively in December 2019. This does not rule out the possibility of the virus having sneaked into the population earlier. By August 2020, the PIMS-TS wave had almost subsided; new cases began to emerge in October 2020, and keep coming in now.

The Pediatric Research and Clinical Center for Infectious Diseases admitted the first patient with PIMS-TS in October 2020; over the course of 4 weeks starting from late December 2020, 14 more children with PIMS-TS were hospitalized. In contrast to Kawasaki disease, all admitted patients were older than 4 years, of them $53 \%$ were girls $(n=8)$. The mean age of the children was $11.25 \pm 3.28$ years for boys and $8.75 \pm 3.99$ years for girls. All the children were hospitalized for persistent fever lasting for over 3 days (3.77 \pm 2.08 days). Of them,
$20 \%$ were hospitalized on day 1-2 after onset, the rest were admitted on day $4.46 \pm 1.66$ after onset. The main referral diagnosis was acute respiratory infection $(53 \% ; n=8)$ or acute gastroenteritis (33.3\%; $n=5)$. On admission, $67 \%$ of children had exanthema and $30 \%$ had diarrhea. Markers of pronounced systemic inflammation were detected by laboratory tests in all patients at the time of admission: C-reactive protein was elevated (>150 mg/L) in $100 \%$ cases; 8 out of 10 children who took a procalcitonin test had high procalcitonin levels. In all cases, signs of cardiac injury were detected. In one case, the patient had a history of the novel coronavirus infection (2 months before admission to the Center); 3 children (20\%) had a history of contact with a potentially infected person; 14 children (93.3\%) had IgG against SARS-CoV-2. PCR tests showed that all collected naso- and oropharyngeal swabs were negative for SARS-CoV-2.

In order to understand the etiology of the disease, a few laboratory tests were conducted. In $66.7 \%(n=10)$ of cases, the pathogen was identified (mostly enteroviruses and Yersiniaceae). Two or more pathogens that could cause the symptoms were implicated in $20 \%$ of cases. But the confirmed presence of the pathogen could not explain the severity of inflammation and the frequency of organ involvement, including the heart, in initially healthy children.

\section{CONCLUSION}

Currently, PIMS-TS is a diagnosis by exclusion. However, it is not fully clear whether PIMS-TS should be excluded in the presence of other etiologic factors contributing to the disease. There is no clear understanding whether PIMS-TS is an independent disease that develops in children with a history of COVID-19 or a pathologic immune response to other 
etiologic agents in patients recovering from mild/asymptomatic COVID-19. More data, including laboratory testing results, are needed about the course of different infections in children and adolescents with a past history of COVID-19.

We cannot predict whether a child is at risk for PIMS-TS after contracting a co-infection, considering that COVID-19 is asymptomatic in most children and teenagers.

A child at risk for PIMS-TS may present at any specialist, including a pediatrician or a specialist in infectious diseases. The doctor will be responsible for making a decision on hospitalization or immediate initiation of therapy. Although all clinicians are familiar with the clinical guidelines for the management of patients with COVID-19, many of them do not have sufficient knowledge about PIMS-TS and are not aware of the approaches to its treatment. In contrast to Kawasaki disease, there is no evidence that intravenous immunoglobulins have any advantages over other therapies or are indicated for PIMS-TS. There are not clear indications and regimens for anticytokine therapy in children with PIMS-TS. Treatment strategies for such patients are borrowed from clinical rheumatology and hematology, which treat similar conditions, including Kawasaki disease, macrophage activation syndrome and hemophagocytic lymphohistiocytosis.

So far, there are no clear, practical recommendations for identifying patients with suspected or likely PIMS-TS that would help to determine the treatment strategy at different stages of the disease.

PIMS-TS is a multidisciplinary problem. Due to multiorgan involvement, the team of specialists delivering medical care to such patients should include infectious disease specialists, critical care physicians, cardiologists, rheumatologists, radiographers and specialists in functional diagnostics. Patients with PIMS-TS require ICU and cardiovascular monitoring equipment and well-equipped laboratories.

There is no consensus protocol for managing children with PIMS-TS. Russian and foreign guidelines recommend antibiotics, intravenous immunoglobulins, aspirin, glucocorticoids, recombinant interleukin-1 receptor antagonist (anakinra), IL6 inhibitor (tocilizumab), monoclonal antibodies against TNF $\alpha$ (infliximab) [22, 31]. Criteria for assessing indications for different anti-PIMS-TS regimens are yet to be developed.

We do not know long-term sequalae of PIMS-TS. As is the case with Kawasaki disease, there is a possibility that PIMS-TS may cause severe cardiovascular complications not only in the acute stage of the disease but also in the long run. After recovering from Kawasaki disease, patients are followed up by their cardiologists. For PIMS-TS, the follow-up strategy has not been proposed yet. Regardless of the clinical type of PIMSTS, children with a history of this disease must be followed up by their pediatrician. It is important to monitor their hemostatic parameters and perform electro- and echocardiography on a regular basis; such patients should be referred to a cardiologist, neurologist or other specialists should the need arise or should there be signs of damage to other organs.

In 2020, the world faced the first global pandemic of the novel coronavirus disease caused by SARS-COV2 and PIMS-TS. PIMS-TS is a multidisciplinary problem that cannot be solved in the absence of multicenter studies. A task force has been created in Saint Petersburg to study various aspects of PIMS-TS, collect epidemiologic data, information on the clinical course and features of the disease, develop optimal diagnostic strategies and therapeutic regimens for PIMS-TS that could be used in a clinical setting, propose schemes for patient routing in the acute stage of the disease and after discharge home, and provide guidelines for follow-up and rehabilitation.

Although it is very difficult to predict the dynamics of the COPVID-19 epidemic, an association can be established between the rise in PIMS-TS cases and the growing number of COVID-19 patients in the population, which has been reported since the spring of 2020 in USA and some European countries and since the fall of 2020 in Russia. The only realistic method of controlling the spread of COVID-19 is vaccination. Given the severity of PIMS-TS and its unpredictable sequelae, vaccination against COVID-19 for children and adolescents should be considered.

\section{References}

1. WHO Coronavirus (COVID-19) Dashboard. 2021 Apr (cited 2021 Apr 07). Available from: https://covid19.who.int/ .

2. Ludvigsson JF. Systematic review of COVID-19 in children shows milder cases and a better prognosis than adults. Acta Paediatr 2020; 109: 1088-95. PMID: 32202343 DOI: 10.1111/apa.15270.

3. Ding Y, Yan H, Guo W. Clinical Characteristics of Children with COVID-19: A Meta-Analysis. Front Pediatr 2020; 8: 431. PMID: 32719759 DOI: 10.3389/fped.2020.00431.

4. Guo CX, He L, Yin JY, Meng XG, Tan W, Yang GP, et al. Epidemiological and clinical features of pediatric COVID-19. BMC Med 2020; 18: 250. PMID: 32762696 DOI:10.1186/s12916-02001719-2.

5. Uskov AN, Lobzin JuV, Rychkova SV, Babachenko IV, Fedorov W, Uluhanova LU i dr. Techenie novoj koronavirusnoj infekcii u detej: nekotorye aspekty monitoringa zabolevaemosti i analiza letal'nosti. Zhurnal infektologii. 2020; 12 (3): 12-20. DOI: 10.22625/20726732-2020-12-3-12-20. Russian.

6. Leidman E, Duca LM, Omura JD, Proia K, Stephens JW, SauberSchatz EK. COVID-19 Trends Among Persons Aged 0-24 Years United States, March 1-December 12, 2020. MMWR Morb Mortal Wkly Rep. 2021; 70 (3): 88-94. DOI: 10.15585/mmwr. mm7003e1. PMID: 33476314; PMCID: PMC7821770.

7. Jones VG, Mills M, Suarez D, Hogan CA, Yeh D, Segal JB, et al. COVID-19 and Kawasaki Disease: Novel Virus and Novel

Case. Hosp Pediatr. 2020; 10 (6): 537-40. DOI: 10.1542/ hpeds.2020-0123. Epub 2020 Apr 7. PMID: 32265235.

8. Davies P, Evans C, Kanthimathinathan HK, Lillie J, Brierley J, Waters G, et al. Intensive care admissions of children with paediatric inflammatory multisystem syndrome temporally associated with SARS-CoV-2 (PIMS-TS) in the UK: a multicentre observational study. Lancet Child Adolesc Health. 2020; 4 (9): 669-77. DOI: 10.1016/S2352-4642(20)30215-7. PMID: 32653054; PMCID: PMC7347350.

9. Verdoni L, Mazza A, Gervasoni A, Martelli L, Ruggeri M, Ciuffreda M, et al. An outbreak of severe Kawasaki-like disease at the Italian epicentre of the SARS-CoV-2 epidemic: an observational cohort study. Lancet. 2020; 395 (10239): 1771-8. DOI: 10.1016/S01406736(20)31103-X. PMID: 32410760; PMCID: PMC7220177.

10. Rowley AH. Understanding SARS-CoV-2-related multisystem inflammatory syndrome in children. Nat Rev Immunol. 2020; 20 (8): 453-4. DOI: 10.1038/s41577-020-0367-5. PMID: 32546853; PMCID: PMC7296515.

11. Evans C, Davies P. SARS-CoV-2 paediatric inflammatory syndrome. Paediatr Child Health (Oxford). 2021; 31 (3): 110-5. DOI: 10.1016/j.paed.2020.12.003. PMID: 33391390; PMCID: PMC7762804.

12. Dolhnikoff M, Ferreira Ferranti J, de Almeida Monteiro RA, DuarteNeto AN, Soares Gomes-Gouvêa M, Viu Degaspare N, et al. 
SARS-CoV-2 in cardiac tissue of a child with COVID-19-related multisystem inflammatory syndrome. Lancet Child Adolesc Health. 2020; 4 (10): 790-4. DOI: 10.1016/S2352-4642(20)30257-1. PMID: 32828177; PMCID: PMC7440866.

13. Bregel LV, Kostik MM, Fell LZ, Efremova OS, Soboleva MK, Krupskaja TS i dr. Bolezn' Kavasaki i mul'tisistemnyj vospalitel'ny] sindrom pri infekcii COVID-19 u detej. Pediatrija im. G. N. Speranskogo. 2020; 99 (6): 209-19. DOI: 10.24110/0031-403X2020-99-6-209-219. Russian.

14. Ravelli $A$, Minoia F, Davì $S$, Horne A, Bovis F, Pistorio A, et al. 2016 Classification Criteria for Macrophage Activation Syndrome Complicating Systemic Juvenile Idiopathic Arthritis: A European League Against Rheumatism/American College of Rheumatology/ Paediatric Rheumatology International Trials Organisation Collaborative Initiative. Ann Rheum Dis. 2016;75(3):481-9. DOI: 10.1136/annrheumdis-2015-208982. PMID: 26865703.

15. Toubiana J, Poirault C, Corsia A, Bajolle F, Fourgeaud J, Angoulvant $F$, et al. Kawasaki-like multisystem inflammatory syndrome in children during the covid-19 pandemic in Paris, France: prospective observational study. BMJ. 2020; 369: m2094. DOI: 10.1136/bmj.m2094. PMID: 32493739; PMCID: PMC7500538.

16. Consiglio C, Cotugno N, Sardh $F$, et al. The immunology of multisystem inflammatory syndrome in children with COVID-19. 2020; 12; 183 (4): 968-81.e7. DOI: 10.1016/j.cell.2020.09.016. PMID: 32966765; PMCID: PMC7474869.

17. Gruber CN, Patel RS, Trachtman R, Lepow L, Amanat F, Krammer F, et al. Mapping Systemic Inflammation and Antibody Responses in Multisystem Inflammatory Syndrome in Children (MIS-C). Cell. 2020; 183 (4): 982-95.e14. DOI: 10.1016/..cell.2020.09.034. PMID: 32991843; PMCID: PMC7489877.

18. Hoste L, Van Paemel R, Haerynck F. Multisystem inflammatory syndrome in children related to COVID-19: a systematic review. Eur J Pediatr. 2021; 18: 1-16. DOI: 10.1007/s00431-021-039935. PMID: 33599835; PMCID: PMC7890544.

19. Yasuhara J, Watanabe K, Takagi H, Sumitomo N, Kuno T. COVID-19 and multisystem inflammatory syndrome in children: A systematic review and meta-analysis. Pediatr Pulmonol. 2021; 11: 10.1002/ppul.25245. DOI: 10.1002/ppul.25245. PMID: 33428826; PMCID: PMC801339.

20. Tang Y, Li W, Baskota M, Zhou Q, Fu Z, Luo Z, et al. Multisystem inflammatory syndrome in children during the coronavirus disease 2019 (COVID-19) pandemic: a systematic review of published case studies. Transl Pediatr. 2021; 10 (1): 121-35. DOI: 10.21037/ tp-20-188. PMID: 33633944; PMCID: PMC7882293.

21. Daskalakis D. Health Alert\# 13: pediatric multi-system inflammatory syndrome potentially associated with COVID-19 // NYC Health [Internet]. 2020 May [cited 2021 Apr 07]. Available from: https://www1.nyc.gov/assets/doh/downloads/pdf/han/

\section{Литература}

1. WHO Coronavirus (COVID-19) Dashboard. 2021 Apr (cited 2021 Apr 07). Available from: https://covid19.who.int/

2. Ludvigsson JF. Systematic review of COVID-19 in children shows milder cases and a better prognosis than adults. Acta Paediat 2020; 109: 1088-95. PMID: 32202343 DOI: 10.1111/apa.15270.

3. Ding Y, Yan H, Guo W. Clinical Characteristics of Children with COVID-19: A Meta-Analysis. Front Pediatr 2020; 8: 431. PMID: 32719759 DOI: 10.3389/fped.2020.00431.

4. Guo CX, He L, Yin JY, Meng XG, Tan W, Yang GP, et al. Epidemiological and clinical features of pediatric COVID-19. BMC Med 2020; 18: 250. PMID: 32762696 DOI:10.1186/s12916-02001719-2.

5. Усков А. Н., Лобзин Ю. В., Рычкова С. В., Бабаченко И. В., Федоров В. В., Улуханова Л. У. и др. Течение новой коронавирусной инфекции у детей: некоторые аспекть мониторинга заболеваемости и анализа летальности. Журнал инфектологии. 2020; 12 (3): 12-20. DOI: 10.22625/2072-67322020-12-3-12-20.

6. Leidman E, Duca LM, Omura JD, Proia K, Stephens JW, SauberSchatz EK. COVID-19 Trends Among Persons Aged 0-24 Years - alert/2020/covid-19-pediatric-multi-system-inflammatorysyndrome.pdf.

22. Ahmed M, Advani S, Moreira A, Zoretic S, Martinez J, Chorath K, et al. Multisystem inflammatory syndrome in children: A systematic review. EClinicalMedicine. 2020; 26: 100527. DOI: 10.1016/j. eclinm.2020.100527. PMID: 32923992; PMCID: PMC7473262.

23. Jindal AK, Pilania RK, Prithvi A, Guleria S, Singh S. Kawasaki disease: characteristics, diagnosis, and unusual presentations. Expert Rev Clin Immunol. 2019; 15 (10): 1089-104. DOI: 10.1080/1744666X.2019.1659726. PMID: 31456443.

24. Whittaker E, Bamford A, Kenny J, Kaforou M, Jones CE, Shah P, et al. PIMS-TS Study Group and EUCLIDS and PERFORM Consortia. Clinical Characteristics of 58 Children With a Pediatric Inflammatory Multisystem Syndrome Temporally Associated With SARS-CoV-2. JAMA. 2020; 324 (3): 259-69. DOI: 10.1001/ jama.2020.10369. PMID: 32511692; PMCID: PMC7281356.

25. WuL, O'KaneAM, Peng H, BiY, Motriuk-SmithD, RenJ. SARS-CoV-2 and cardiovascular complications: From molecular mechanisms to pharmaceutical management. Biochem Pharmacol. 2020; 178: 114114. DOI: 10.1016/j.bcp.2020.114114. PMID: 32579957; PMCID: PMC7306106.

26. Royal College of Paediatric and Child Health. Guidance: paediatric multisystem inflammatory syndrome temporally associated with COVID-19. 2020 May 01 (cited 2021 Apr 07). Available from: https://www.rcpch.ac.uk/resources/guidance-paediatricmultisystem-inflammatory-syndrome-temporally-associatedcovid-19.

27. Cuomo AM, Zucker HA, Dreslin S. Health advisory: pediatric multi-system inflammatory syndrome potentially associated with coronavirus disease (COVID-19) children //New York State of Opportunity. Department of Health. 2020 May 06 (cited 2021 Jan 24). Available from: https://www.health.ny.gov/ press/releases/2020/docs/2020-05- 06_covid19_pediatric_ inflammatory_syndrome.pdf.

28. Lobzin JuV, Vilnic AA, Kostik MM i dr. Pediatricheskij mul'tisistemnyj vospalitel'nyj sindrom, associirovannyj s novoj koronavirusnoj infekciej: nereshennye problemy. Zhurnal infektologii. 2021; 13 (1): 13-20. https://doi.org/10.22625/2072-6732-2021-13-1-13-20. Russian.

29. Kawasaki T. Kawasaki disease. Proc Jpn Acad Ser B Phys Biol Sci. 2006; 82 (2): 59-71. DOI: 10.2183/pjab.82.59. PMID: 25792773; PMCID: PMC4323050

30. Kawasaki T. Kawasaki disease. Int J Rheum Dis. 2014; 17 (5): 597-600. DOI: 10.1111/1756-185X.12408.

31. Aleksandrovich JuS, Alekseeva El, Bakradze MD i dr. Osobennosti klinicheskih projavlenij i lechenija zabolevanija, vyzvannogo novoj koronavirusnoj infekciej (COVID-19), u detej. Metodicheskie rekomendacii. Versija 2. Pediatricheskaja farmakologija. 2020; 17 (3): 187-212. DOI: 10.15690/pf.v17i3.2123. Russian.

United States, March 1-December 12, 2020. MMWR Morb Mortal Wkly Rep. 2021; 70 (3): 88-94. DOI: 10.15585/mmwr. mm7003e1. PMID: 33476314; PMCID: PMC7821770.

7. Jones VG, Mills M, Suarez D, Hogan CA, Yeh D, Segal JB, et al. COVID-19 and Kawasaki Disease: Novel Virus and Novel Case. Hosp Pediatr. 2020; 10 (6): 537-40. DOI: 10.1542/ hpeds.2020-0123. Epub 2020 Apr 7. PMID: 32265235.

8. Davies P, Evans C, Kanthimathinathan HK, Lillie J, Brierley J, Waters G, et al. Intensive care admissions of children with paediatric inflammatory multisystem syndrome temporally associated with SARS-CoV-2 (PIMS-TS) in the UK: a multicentre observational study. Lancet Child Adolesc Health. 2020; 4 (9): 669-77. DOI: 10.1016/S2352-4642(20)30215-7. PMID: 32653054; PMCID: PMC7347350.

9. Verdoni L, Mazza A, Gervasoni A, Martelli L, Ruggeri M, Ciuffreda M, et al. An outbreak of severe Kawasaki-like disease at the Italian epicentre of the SARS-CoV-2 epidemic: an observational cohort study. Lancet. 2020; 395 (10239): 1771-8. DOI: 10.1016/S01406736(20)31103-X. PMID: 32410760; PMCID: PMC7220177.

10. Rowley $\mathrm{AH}$. Understanding SARS-CoV-2-related multisystem 
inflammatory syndrome in children. Nat Rev Immunol. 2020; 20 (8): 453-4. DOI: 10.1038/s41577-020-0367-5. PMID: 32546853; PMCID: PMC7296515.

11. Evans C, Davies P. SARS-CoV-2 paediatric inflammatory syndrome. Paediatr Child Health (Oxford). 2021; 31 (3): 110-5. DOI: 10.1016/j.paed.2020.12.003. PMID: 33391390; PMCID: PMC7762804.

12. Dolhnikoff M, Ferreira Ferranti J, de Almeida Monteiro RA, DuarteNeto AN, Soares Gomes-Gouvêa M, Viu Degaspare N, et al. SARS-CoV-2 in cardiac tissue of a child with COVID-19-related multisystem inflammatory syndrome. Lancet Child Adolesc Health. 2020; 4 (10): 790-4. DOI: 10.1016/S2352-4642(20)30257-1. PMID: 32828177; PMCID: PMC7440866.

13. Брегель Л. В., Костик М. М., Фелль Л. З., Ефремова О. С., Соболева М. К., Крупская Т. С. и др. Болезнь Кавасаки и мультисистемный воспалительный синдром при инфекции COVID-19 у детей. Педиатрия им. Г. Н. Сперанского. 2020; 99 (6): 209-19. DOI: 10.24110/0031-403X-2020-99-6-209-219.

14. Ravelli $A$, Minoia F, Davì $S$, Horne $A$, Bovis F, Pistorio A, et al. 2016 Classification Criteria for Macrophage Activation Syndrome Complicating Systemic Juvenile Idiopathic Arthritis: A European League Against Rheumatism/American College of Rheumatology/ Paediatric Rheumatology International Trials Organisation Collaborative Initiative. Ann Rheum Dis. 2016;75(3):481-9. DOl: 10.1136/annrheumdis-2015-208982. PMID: 26865703.

15. Toubiana J, Poirault C, Corsia A, Bajolle F, Fourgeaud J, Angoulvant $F$, et al. Kawasaki-like multisystem inflammatory syndrome in children during the covid-19 pandemic in Paris, France: prospective observational study. BMJ. 2020; 369: m2094. DOI: 10.1136/bmj.m2094. PMID: 32493739; PMCID: PMC7500538.

16. Consiglio C, Cotugno N, Sardh F, et al. The immunology of multisystem inflammatory syndrome in children with COVID-19. 2020; 12; 183 (4): 968-81.e7. DOI: 10.1016/..cell.2020.09.016. PMID: 32966765; PMCID: PMC7474869.

17. Gruber CN, Patel RS, Trachtman R, Lepow L, Amanat F, Krammer F, et al. Mapping Systemic Inflammation and Antibody Responses in Multisystem Inflammatory Syndrome in Children (MIS-C). Cell. 2020; 183 (4): 982-95.e14. DOI: 10.1016/j.cell.2020.09.034. PMID: 32991843; PMCID: PMC7489877.

18. Hoste L, Van Paemel R, Haerynck F. Multisystem inflammatory syndrome in children related to COVID-19: a systematic review. Eur J Pediatr. 2021; 18: 1-16. DOI: 10.1007/s00431-021-039935. PMID: 33599835; PMCID: PMC7890544.

19. Yasuhara J, Watanabe $\mathrm{K}$, Takagi $\mathrm{H}$, Sumitomo $\mathrm{N}$, Kuno $\mathrm{T}$. COVID-19 and multisystem inflammatory syndrome in children: A systematic review and meta-analysis. Pediatr Pulmonol. 2021; 11: 10.1002/ppul.25245. DOI: 10.1002/ppul.25245. PMID: 33428826; PMCID: PMC801339.

20. Tang Y, Li W, Baskota M, Zhou Q, Fu Z, Luo Z, et al. Multisystem inflammatory syndrome in children during the coronavirus disease 2019 (COVID-19) pandemic: a systematic review of published case studies. Transl Pediatr. 2021; 10 (1): 121-35. DOI: 10.21037/ tp-20-188. PMID: 33633944; PMCID: PMC7882293.
21. Daskalakis D. Health Alert\# 13: pediatric multi-system inflammatory syndrome potentially associated with COVID-19 // NYC Health [Internet]. 2020 May [cited 2021 Apr 07]. Available from: https://www1.nyc.gov/assets/doh/downloads/pdf/han/ alert/2020/covid-19-pediatric-multi-system-inflammatorysyndrome.pdf.

22. Ahmed M, Advani S, Moreira A, Zoretic S, Martinez J, Chorath K, et al. Multisystem inflammatory syndrome in children: A systematic review. EClinicalMedicine. 2020; 26: 100527. DOI: 10.1016/j. eclinm.2020.100527. PMID: 32923992; PMCID: PMC7473262.

23. Jindal AK, Pilania RK, Prithvi A, Guleria S, Singh S. Kawasaki disease: characteristics, diagnosis, and unusual presentations. Expert Rev Clin Immunol. 2019; 15 (10): 1089-104. DOI: 10.1080/1744666X.2019.1659726. PMID: 31456443.

24. Whittaker E, Bamford A, Kenny J, Kaforou M, Jones CE, Shah P, et al. PIMS-TS Study Group and EUCLIDS and PERFORM Consortia. Clinical Characteristics of 58 Children With a Pediatric Inflammatory Multisystem Syndrome Temporally Associated With SARS-CoV-2. JAMA. 2020; 324 (3): 259-69. DOI: 10.1001/ jama.2020.10369. PMID: 32511692; PMCID: PMC7281356.

25. WuL, O'KaneAM, Peng H, BiY, Motriuk-SmithD, Ren J. SARS-CoV-2 and cardiovascular complications: From molecular mechanisms to pharmaceutical management. Biochem Pharmacol. 2020; 178: 114114. DOI: 10.1016/j.bcp.2020.114114. PMID: 32579957; PMCID: PMC7306106.

26. Royal College of Paediatric and Child Health. Guidance: paediatric multisystem inflammatory syndrome temporally associated with COVID-19. 2020 May 01 (cited 2021 Apr 07). Available from: https://www.rcpch.ac.uk/resources/guidance-paediatricmultisystem-inflammatory-syndrome-temporally-associatedcovid-19.

27. Cuomo AM, Zucker HA, Dreslin S. Health advisory: pediatric multi-system inflammatory syndrome potentially associated with coronavirus disease (COVID-19) children //New York State of Opportunity. Department of Health. 2020 May 06 (cited 2021 Jan 24). Available from: https://www.health.ny.gov/ press/releases/2020/docs/2020-05- 06_covid19_pediatric_ inflammatory_syndrome.pdf.

28. Лобзин Ю. В., Вильниц А. А., Костик М. М. и др. Педиатрический мультисистемный воспалительный синдром, ассоциированный с новой коронавирусной инфекцией: нерешенные проблемы. Журнал инфектологии. 2021; 13 (1): 13-20. https://doi.org/10.22625/2072-6732-2021-13-1-13-20.

29. Kawasaki T. Kawasaki disease. Proc Jpn Acad Ser B Phys Biol Sci. 2006; 82 (2): 59-71. DOI: 10.2183/pjab.82.59. PMID: 25792773; PMCID: PMC4323050.

30. Kawasaki T. Kawasaki disease. Int J Rheum Dis. 2014; 17 (5): 597-600. DOI: 10.1111/1756-185X.12408.

31. Александрович Ю. С., Алексеева Е. И., Бакрадзе М. Д. и др. Особенности клинических проявлений и лечения заболевания, вызванного новой коронавирусной инфекцией (COVID-19), у детей. Методические рекомендации. Версия 2. Педиатрическая фармакология. 2020; 17 (3): 187-212. DOI: 10.15690/pf.v17i3.2123. 


\title{
EVALUATION OF EFFICACY OF THE AMINO ACID-PEPTIDE COMPLEX ADMINISTERED INTRAGASTRICALLY TO GOLDEN HAMSTERS EXPERIMENTALLY INFECTED WITH SARS-COV-2
}

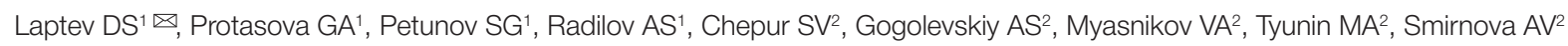

${ }^{1}$ Research Institute of Hygiene, Occupational Pathology and Human Ecology under FMBA, Leningrad region, Russia

${ }^{2}$ State Research and Testing Military Medicine Institute under the Ministry of Defense of the Russian Federation, St. Petersburg, Russia

\begin{abstract}
The development of coronavirus infection outbreak into a pandemic, coupled with the lack of effective COVID-19 therapies, is a challenge for the entire pharmaceutical industry. This study aimed to assess the treatment and preventive efficacy of the amino acid-peptide complex (APC) in male Syrian hamsters infected with SARSCoV-2 (intranasal administration of $26 \mu$ of the virus culture, titer of $\left.4 \times 10^{4} \mathrm{TCD}_{50} / \mathrm{ml}\right)$. In a modeled COVID-19 case, APC administered for treatment and preventive purposes reduced lung damage. Compared to the positive control group, test group had the lung weight factor $15.2 \%$ smaller (trend), which indicates a less pronounced edema. Microscopic examination revealed no alveolar edema, atypical hypertrophied forms of type II alveolocytes, pulmonary parenchyma fibrinization. The macrophage reaction intensified, which is probably a result of the APC-induced activation of regenerative processes in the lung tissues. Spleens of the animals that received APC for therapeutic and preventive purposes were less engorged and had fewer hemorrhages. The decrease of body weight of the test animals that received APC for treatment and prevention was insignificant $(p<0.05)$, which indicates a less severe course of COVID-19. Administered following a purely therapeutic protocol, APC proved ineffective against SARS-CoV-2 post-infection. Thus, APC-based drug used as a therapeutic and preventive agent reduces pulmonary edema and makes morphological signs of lung tissue damage less pronounced in male Syrian hamsters infected with SARS-CoV-2.
\end{abstract}

Keywords: COVID-19, pulmonary edema, atypical pneumocytes, Syrian hamsters

Author contribution: Laptev DS, Protasova GA, Myasnikov VA, Tyunin MA, Smirnova AV — experiment, information collection, data processing; Petunov SG — data processing and interpretation; Radilov AS — scientific concept, consulting; Chepur SV - experiment organization, COVID-19 in vivo model development; Gogolevskiy AS - experiment organization. All authors participated in the manuscript authoring and editing.

Compliance with ethical standards: the study was conducted in conformity to the provisions of the European Convention for the Protection of Vertebrate Animals used for Experimental and other Scientific Purposes.

$\bowtie$ Correspondence should be addressed: Denis S. Laptev

Kapitolovo, str. 93, r.p. Kuzmolovsky, Vsevolozhsky r., 188663; lapden@mail.ru

Received: 21.05.2021 Accepted: 06.06.2021 Published online: 16.06.2021

DOI: $10.47183 /$ mes.2021.011

\section{ОЦЕНКА ЭФФЕКТИВНОСТИ АМИНОКИСЛОТНО-ПЕПТИДНОГО КОМПЛЕКСА ПРИ ВНУТРИЖЕЛУДОЧНОМ ВВЕДЕНИИ ЗОЛОТИСТЫМ ХОМЯКАМ, ЭКСПЕРИМЕНТАЛЬНО ЗАРАЖЕННЫМ SARS-COV-2}

Д. С. Лаптев ${ }^{1}$, Г. А. Протасова', С. Г. Петунов ${ }^{1}$, А. С. Радилов ${ }^{1}$, С. В. Чепур², А. С. Гоголевский², В. А. Мясников², М. А. Тюнин², А. В. Смирнова²

${ }^{1}$ Научно-исследовательский институт гигиены, профпатологии и экологии человека Федерального медико-биологического агентства, Ленинградская область, Россия

2 Государственный научно-исследовательский испытательный институт военной медицины Министерства обороны, Санкт-Петербург, Россия

Распространение коронавирусной инфекции до масштабов мировой пандемии и отсутствие эффективных средств патогенетической терапии COVID-19 являются вызовом для всей фармакологической отрасли. Целью данной работы было оценить эффективность лечебно-профилактического применения аминокислотно-пептидного комплекса (АПК) на самцах сирийских хомяков, подвергнутых заражению SARS-CoV-2 интраназальным введением 26 мкл культуры вируса титром 4 × 104 ТЦД $/$ Мл. Лечебно-профилактическое применение АПК позволяет снизить поражение легких при моделировании COVID-19. Меньший, по сравнению с группой положительного контроля, на 15,2\% (тенденция) весовой коэффициент легких свидетельствует о менее выраженном их отеке. Результаты микроскопического исследования показали отсутствие альвеолярного отека, атипичных гипертросированных форм альвеолоцитов II типа, фибринизации легочной паренхимы. Отмечено усиление макрофагальной реакции, которое, вероятно, является отражением активации АПК регенераторных процессов в тканях легких. В селезенке животных, получавших АПК в лечебно-профилактических целях, выявлена меньшая степень гиперемии с участками кровоизлияний. Отсутствие статистически значимой ( $<<0,05)$ отрицательной динамики массы тела при лечебнопрофилактическом применении AПК отражает снижение общей тяжести течения заболевания COVID-19. Использование AПK по лечебной схеме после заражения SARS-CoV-2 оказалось неэффективным. Таким образом, применение препарата на основе АПК в качестве лечебно-профилактического средства вызывает снижение отека легких и уменьшение морфологических признаков повреждения легочной ткани у самцов сирийских хомяков, подвергнутых заражению SARS-CoV-2.

Ключевые слова: COVID-19, отек легких, атипичные пневмоциты, сирийские хомяки

Вклад авторов: Д. С. Лаптев, Г. А. Протасова, В. А. Мясников, М. А. Тюнин, А. В. Смирнова - экспериментальная часть, сбор информации, обработка данных; С. Г. Петунов - обработка и интерпретация данных; А. С. Радилов - научный замысел, консультирование; С. В. Чепур - организация экспериментальной части работы, разработка in vivo модели COVID-19; А. С. Гоголевский — организация экспериментальной части работы. Все авторы участвовали в подготовке и редактировании рукописи статьи.

Соблюдение этических стандартов: исследование выполняли с соблюдением правил биоэтики, утвержденных Европейской конвенцией о защите позвоночных животных, используемых для экспериментальных и других целей.

$\searrow$ Для корреспонденции: Денис Сергеевич Лаптев

ст. Капитолово, корп. 93, г. п. Кузьмоловский, Всеволожский район, 188663; lapden@mail.ru

Статья получена: 21.05.2021 Статья принята к печати: 06.06.2021 Опубликована онлайн: 16.06.2021

DOI: $10.47183 /$ mes.2021.011 
Despite all the quarantine measures taken, at the turn of 20192020 SARS-CoV-2, a coronavirus causing COVID-19, quickly spread through the Chinese provinces first and then all around the world. According to the World Health Organization, by March 2020 coronavirus infection reached proportions of a pandemic.

According to the published literature, the "gateway" for SARS-CoV-2 infection are cells expressing angiotensinconverting enzyme 2 (ACE2) receptors: respiratory tract epithelium, alveolocytes, vascular endothelium, epithelium of the gastrointestinal tract, myocardium and some parts of the central nervous system [1]. The virus replicates in type II alveolocytes, the replication producing a large number of viral particles. Apoptosis of the affected cells disrupts the pulmonary ventilation and perfusion processes, promotes accumulation of fluid in the alveoli and causes diffuse damage thereof [2].

Joint research effort by scientists from many countries yielded successful development of SARS-CoV-2 vaccines [3], which, provided the vaccination campaigns are largescale, will significantly reduce the number of severe and fatal cases. However, the question of development of effective and safe medications preventing COVID-19 progression into lifethreatening forms remains urgent [4]. Current research and development efforts focus on innovative and cost-effective therapies relying on monoclonal antibodies that would reduce the risk of development of COVID-19 complications [5, 6], as well as on the new approaches to suppress the cytokine storm with the help of opioid peptides that inhibit expression of proinflammatory cytokines by immune cells through suppression of translocation of the nuclear factor kappa $B(N F-\kappa B)$ active dimer [7].

Syrian hamster is the most suitable and accessible experimental model that can be used for preclinical assessment of the efficacy of pharmaceutical drugs against respiratory dysfunction that develops as part of COVID-19 course [8]. Infected with SARS-CoV-2, these animals exhibit clinical picture, viral kinetics, histopathological changes and immune responses very similar to those registered in coronavirus patients [9]. During the first week after infection, the animals had pronounced clinical signs of COVID-19. Rapid respiration and weight loss accompanied histopathological changes, from the initial exudative phase of diffuse damage to the alveoli and extensive apoptosis to a later proliferative phase of tissue repair. There was also registered spleen atrophy, which is probably associated with pronounced activation of cytokines [10].

Since the main causes of death in COVID-19 cases are pulmonary edema, pneumonia and respiratory failure resulting from the virus affecting alveolar cells in the lung's respiratory parts, it seems appropriate to conduct a preclinical study of the drug based on the amino acid-peptide complex (APC) that proved to have an anti-edema effect in an ex vivo pilot study involving isolated rat lungs. The protective effect manifested in slower (1.5 times) increase of the isolated lung-heart complex mass in the test group compared to the control group $(p<0.05)$, the rate measured during 90-minute perfusion, which reflects the rate and degree of development of pulmonary edema [11].

Thus, the purpose of this work was to assess the efficacy of application of the experimental APC for therapeutic and therapeutic and preventive purposes in the male Syrian hamster COVID-19 model.

\section{METHODS}

SARS-CoV-2 was isolated from a clinical sample obtained from a sick patient. The oropharyngeal swab was collected into a $15 \mathrm{~mm}$ tube with DMEM medium (Lonza; Switzerland) without serum and transported to the laboratory. The sample was filtered through a $0.2 \mu \mathrm{m}$ syringe filter on the same day. The virus was isolated and accumulated on a Vero (B) cell culture (BiolT; Russia) in EMEM medium with L-glutasin (BiolT; Russia) with $2 \%$ of fetal bovine serum (BiolT; Russia) and $1 \%$ of antibiotic-antimycotics (Gibco; USA). After each passage employing the real-time polymerase chain reaction reverse transcription method (RT-PCR-RT), we determined the presence of the virus and its titer growth against the original sample with the help of the commercially available Detection Kit for 2019 Novel Coronavirus (2019-nCoV) RNA (PCRFluorescence Probing) (Sun Yat-sen University; China). Having analyzed the virus nucleotide sequence, we established it belonged to GR subclass. The infectious activity of SARSCoV-2 was determined on a Vero (B) cell culture in 96-well plates; the tissue culture infective dose (TCID) was established with the help of the Reed-Muench method [12]. The animals were infected with viral culture of the fifth passage, the titer of which was $4 \times 10^{4} \mathrm{TCD}_{50} / \mathrm{ml}$. The virus was introduced intranasally, with a mechanical Eppendorf dispenser, $13 \mu \mathrm{L}$ into each nostril followed by a controlled inhale.

The test animals were outbred male golden Syrian hamsters Mesocricetus auratus aged 4-6 weeks (body weight of 80-100 g), obtained from the nursery of ZAO NPO Dom farmacii (St. Petersburg). The animals were kept in conditions prescribed by the Directive 2010/63/EU of the European Parliament and of the Council of the European Union of September 22, 2010 (on protection of animals used for scientific purposes) [13]. The controlled parameters were room microclimate (temperature, humidity, air exchange rate), quality of feed and bedding material. The animals were on a standard diet; the feed was formed into pellets. As for the lighting, 12 hours were daytime and 12 hours nighttime.

After randomization by body weight, the animals were divided into four experimental groups $(n=10)$.

Group 1, negative control: daily intragastric (i/g) administration of $\mathrm{APC}$, dose $-75 \mathrm{mg} / \mathrm{kg}$, duration -7 days.

Group 2, positive control: single administration of SARS-CoV-2.

Group 3, treatment and prevention protocol: daily intragastric (i/g) administration of APC, dose $-75 \mathrm{mg} / \mathrm{kg}$, duration -7 days; eighth day of the experiment - infection of the animals with SARS-CoV-2.

Table 1. Body weight of Syrian hamsters infected with SARS-CoV-2; absolute and relative data presented as $M \pm$ SE $(n=10)$

\begin{tabular}{|c|c|c|c|}
\hline Group № & Experiment pattern & Background, $\mathrm{g}$ & $\begin{array}{c}\text { On the } 7^{\text {th }} \text { day after infection, } \mathrm{g} \\
7^{\text {th }} \text { day after infection, } \%\end{array}$ \\
\hline 1 & APC & $105.1 \pm 3.5$ & $101.3 \pm 3.9$ \\
\hline 2 & SARS-CoV-2 & $105.4 \pm 2.6$ & $95.0 \pm 2.7^{\#}$ \\
\hline 3 & $\begin{array}{c}\text { SARS-CoV-2 + APC, treatment } \\
\text { and prevention protocol }\end{array}$ & $106.1 \pm 2.9$ & $98.6 \pm 2.6$ \\
\hline 4 & SARS-CoV-2 + APC, treatment protocol & $107.6 \pm 4.6$ & $93.0 \pm 1.1^{*}$ \\
\hline
\end{tabular}

Note: ${ }^{\#}$ — statistically significant difference from the background; * — statistically significant difference from group 1. 
Table 2. Mass ratios of internal organs of Syrian hamsters infected with SARS-CoV-2 (M \pm SE; $n=10)$

\begin{tabular}{|c|c|c|c|}
\hline Group № & Experiment pattern & Lung mass ratio & Spleen mass ratio \\
\hline 1 & APC & $6.6 \pm 0.1$ & $1.6 \pm 0.1$ \\
\hline 2 & SARS-CoV-2 & $10.5 \pm 0.6^{*}$ & $1.7 \pm 0.1$ \\
\hline 3 & $\begin{array}{c}\text { SARS-CoV-2 + APC, treatment } \\
\text { and prevention protocol }\end{array}$ & $8.9 \pm 0.6^{*}$ & $1.4 \pm 0.1^{\#}$ \\
\hline 4 & SARS-CoV-2 + APC, treatment protocol & $9.5 \pm 0.5^{*}$ & $1.5 \pm 0.2$ \\
\hline
\end{tabular}

Note: * — statistically significant difference from group 1; \# — statistically significant difference from group 2.

Group 4, treatment protocol: infection of hamsters with SARS-CoV-2 followed by APC administration in the course of 7 days.

After the infection with SARS-CoV-2, the animals were observed twice a day for signs of COVID-19 (ruffled fur, hunched posture, shortness of breath, anorexia, lethargy) [14]. Body weights were recorded once a day through the study period.

On the eighth day after infection with SARS-CoV-2, all animals were euthanized by an overdose of general anesthetic (Xila, $20.0 \mathrm{mg} / \mathrm{ml}$ and Zoletil 100, $50.0 \mathrm{mg} / \mathrm{ml}, 1: 1$ ratio, 1.0 $\mathrm{ml}$ per $1.0 \mathrm{~kg}$ of body weight, intramuscularly). Subsequently, their internal organs (lungs, heart, spleen) were taken out for the purposes of assessing the mass ratio (the ratio of the mass of the organ (mg) to the total mass (g)) and pathomorphological analysis.

The internal organs were fixed in formalin (10\%). Tissue-Tek VIP closed cycle histology processor (Sakura; Japan) enabled organ dehydration and degreasing, and Tissue-Tek TEC paraffin station (Sakura; Japan) was used to embedded them in paraffin. The fixed sections $5 \mu \mathrm{m}$ thick were made with the help of Accu-Cut SRM 200 rotary microtome (Sakura; Japan). Histological sections were stained with hematoxylin and eosin, picrofuchsin for connective tissue (Van Gieson's stain), Weigert's elastic stain for fibrin. The nucleic acids were identified with pyronine and methyl green stains (Brachet method). The prepared histological sections were analyzed with the help of Axioskop 40 microscope (Carl Zeiss; Germany) with a ProgRes CFscan color digital camera (Carl Zeiss; Germany) relying on special software to video document the results obtained.

GraphPad Prism 5.04 software (GraphPad Software; USA) enabled statistical processing. With the data distribution among the paired samples being normal, comparison relied on the Student's $t$-test. When the distribution of data was different from normal, the Wilcoxon test for paired samples was used. The intergroup differences were assessed with

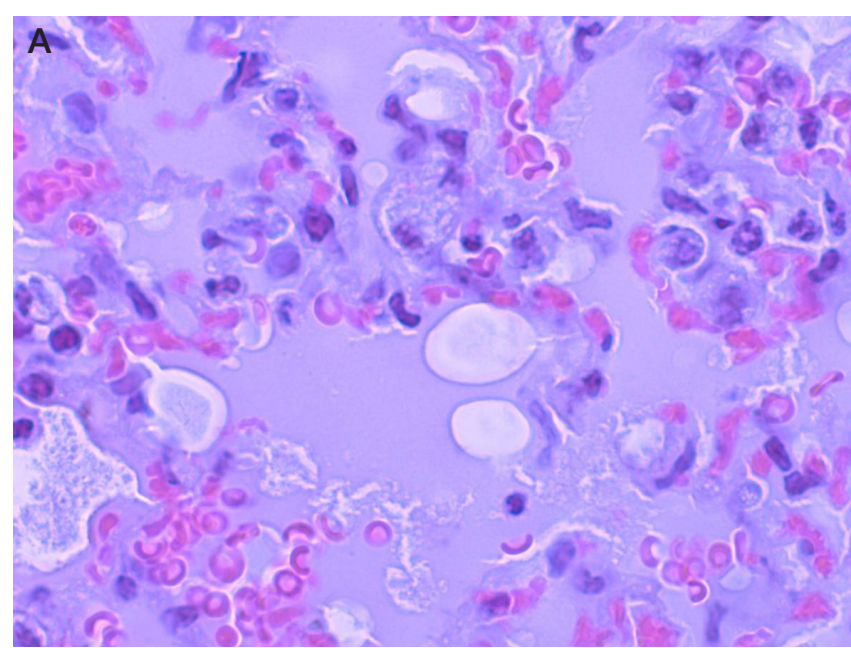

the Mann-Whitney $U$ test. The differences were considered significant at $p \leq 0.05$.

\section{RESULTS}

The experiment established that animals of groups 2 and 4 , which were infected with SARS-CoV-2, statistically significantly lose body weight compared to the animals of the control group 1 (Table 1). The reduction of weight of the group 3 animals, which received APC under the treatment and prevention protocol, was not statistically significant.

All experimental groups had the lung mass ratio increasing to values significantly greater than those registered in the negative control group (APC), but in group 3 (treatment and prevention protocol) this increase was the least pronounced (Table 2). In addition, group 3 animals had their spleen mass ratio decreased significantly.

Pathomorphological analysis of the lungs of group 1 animals revealed a few areas of alveolar hemorrhage and atelectasis in three samples out of five. In addition, it was established that perivascular infiltrates were of predominantly lymphocytic composition. The changes were regarded as spontaneous pathology caused by euthanasia.

Microscopic examination of lung parenchyma revealed that all test animals of group 2 had diffuse alveolar lesions manifested by intra-alveolar edema with an admixture of erythrocytes, macrophages, desquamated damaged alveocytes, lymphocytes (Fig. 1A) and alveolar hemorrhages. Vascular lesions were characterized by thrombosis, perivascular edema and polymorphic cell infiltrates, plasmatization of interalveolar septa and walls of small vessels (Fig. 1B). Also among the findings were hyperplasia and hypertrophy of type II alveolocytes, with pneumocytes of atypical irregular shape and enlarged nuclei and nucleoli (Fig. 2A). Brachet staining allowed a clearer visualization of atypical forms of alveolocytes (Fig. 2B).

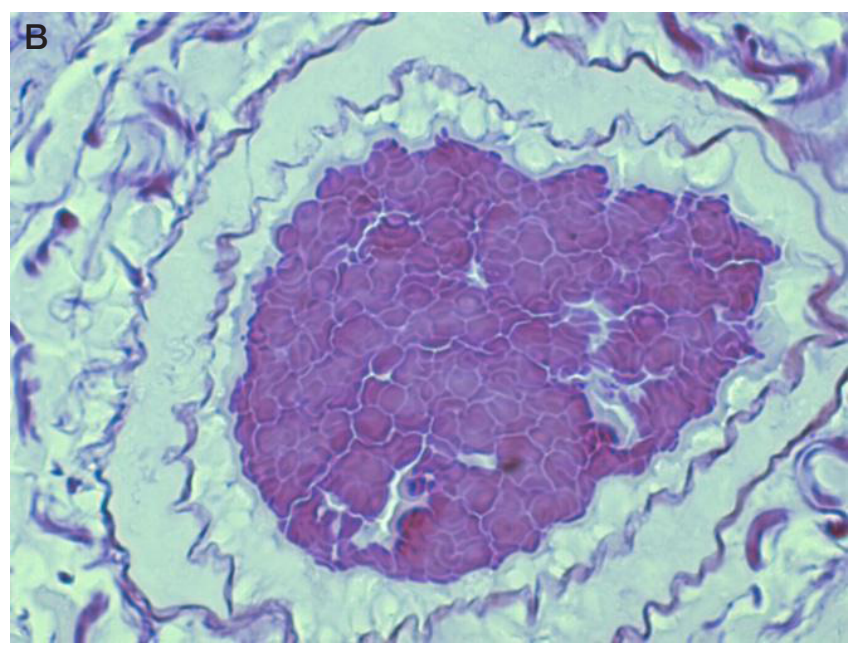

Fig. 1. Lung. Group 2. A. Alveolar edema (stained with hematoxylin and eosin; magnification $\times 1000)$. B. Thrombosis (weigert staining for fibrin; magnification $\times 650$ ) 

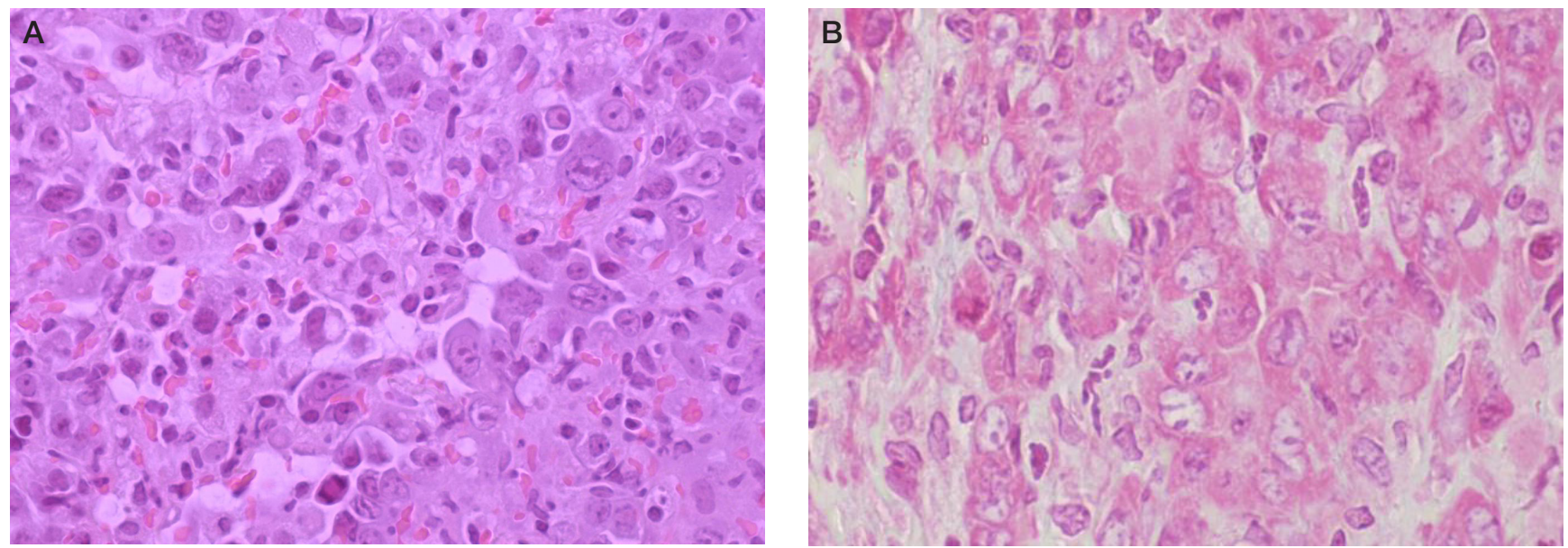

Fig. 2. Lung. Group 2. A. Diffuse alveolar damage, hypertrophied atypical type II alveolocytes (hematoxylin and eosin staining; magnification $\times 650$ ). B. RNA of the cytoplasm of atypical type II alveolocytes stained pink-red, Brachet staining (pyronine and methyl green; magnification $\times 1000$ )

In two test animals of group 2 the lungs had fibroblast proliferation foci with developing tissue granulation. The fibrin in lung parenchyma (discovered with Weigert stain) was diffused (Fig. 3A, B).

In group 3 (treatment and prevention protocol), four our of five animals had their pathomorphological picture characterized by the absence of alveolar pulmonary edema. Microscopy of the lungs revealed peribronchial and perivascular infiltrates, areas of microbleeds in the lung parenchyma (three out of five animals). In addition, hyperplasia of type II alveolocytes
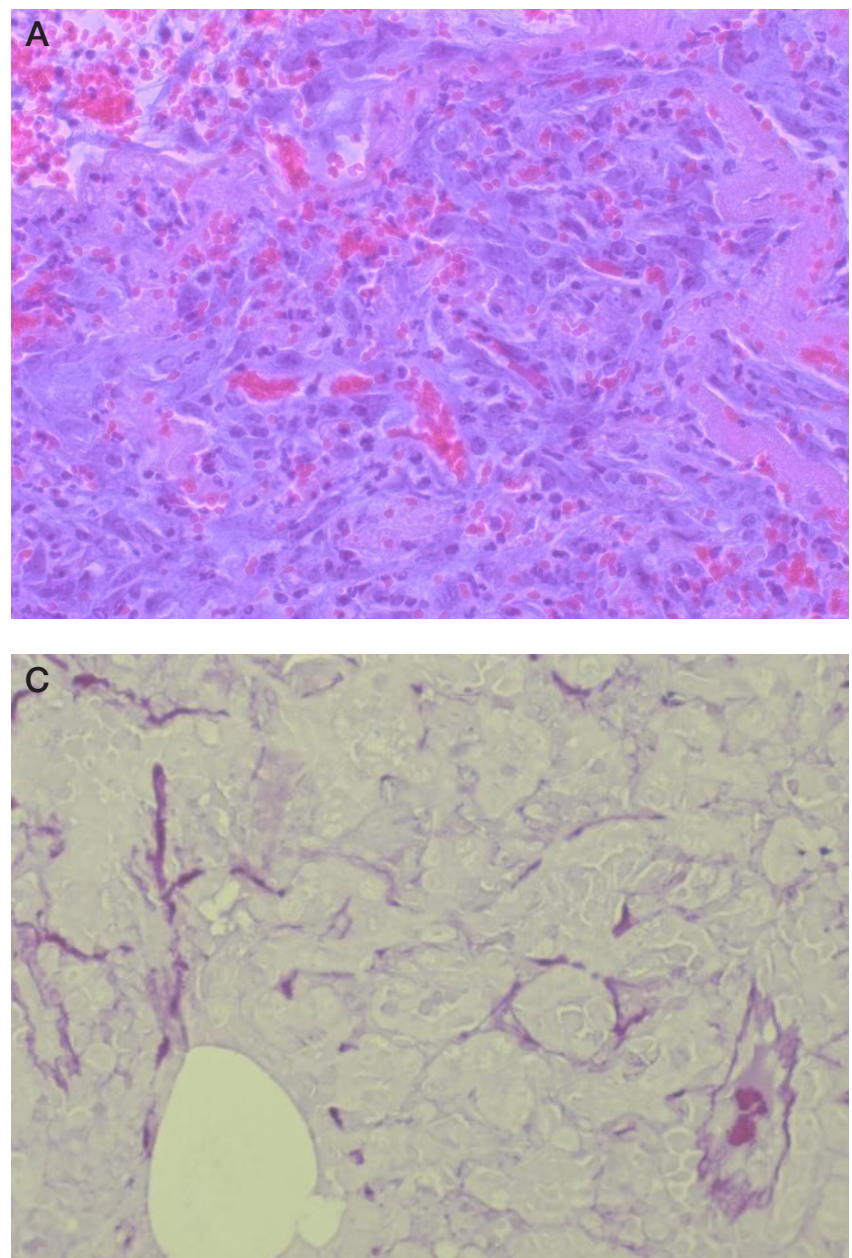

and an increase in macrophage reaction were registered (Fig. 4A, B). Alveolocyte hypertrophy and atypia were observed in only one of five animals. In this group, Weigert staining of lung preparations did not reveal fibrinization of the parenchyma (see Fig. 3D).

Pathomorphological changes in the lungs of group 4 animals were largely the same as the destructive changes in the lung parenchyma of group 2 animals.

The analysis of histological preparations of the heart did not reveal any morphological differences between test groups, with
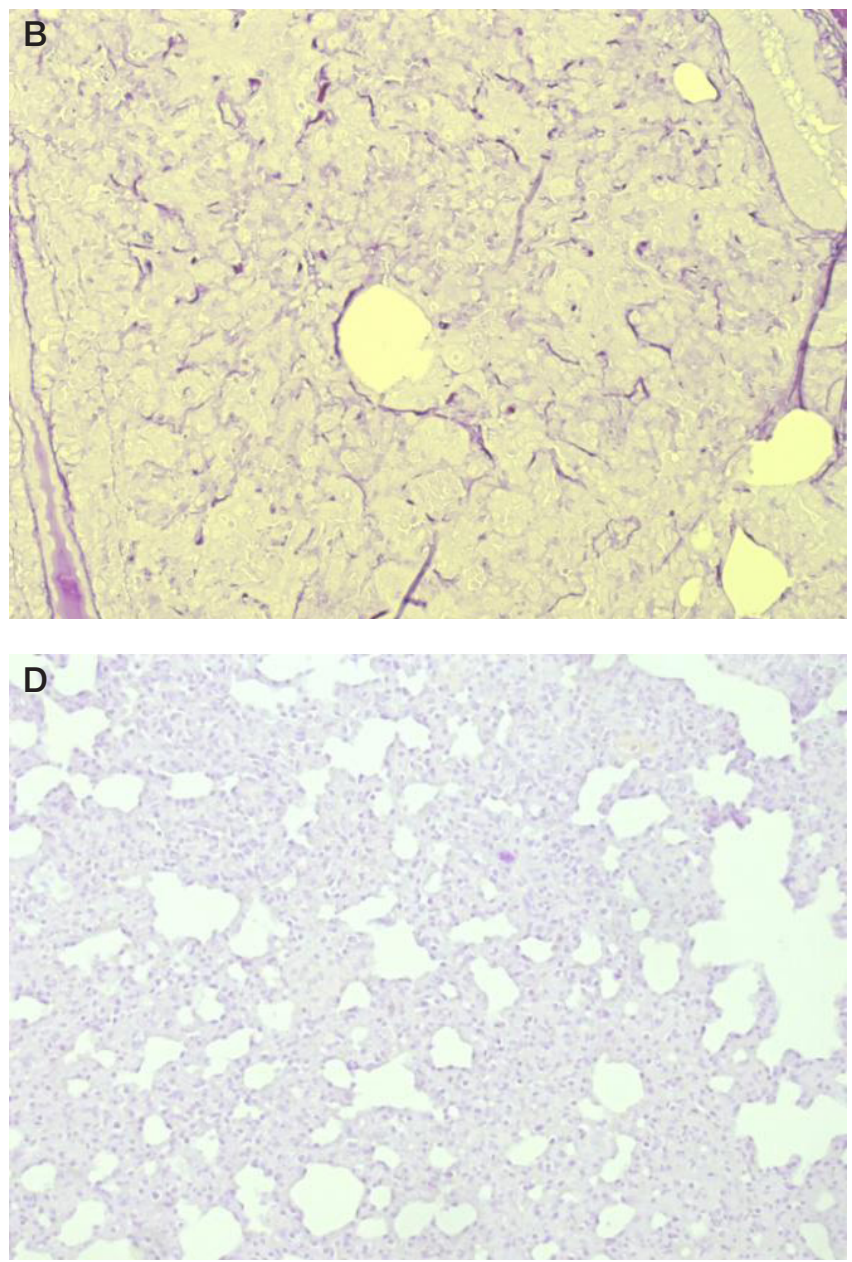

Fig. 3. Lung. Group 2. A. Fibroblast proliferation, focal fibrosis, hemorrhage (staining with hematoxylin and eosin; magnification $\times 400)$. B. Diffuse deposition of fibrin in the parenchyma (magnification $\times 200$ ). C. Fibrin deposits in lung parenchyma (magnification $\times 400$ ). D. Group 3, no fibrin (weigert staining for fibrin; magnification $\times 200$ ) 

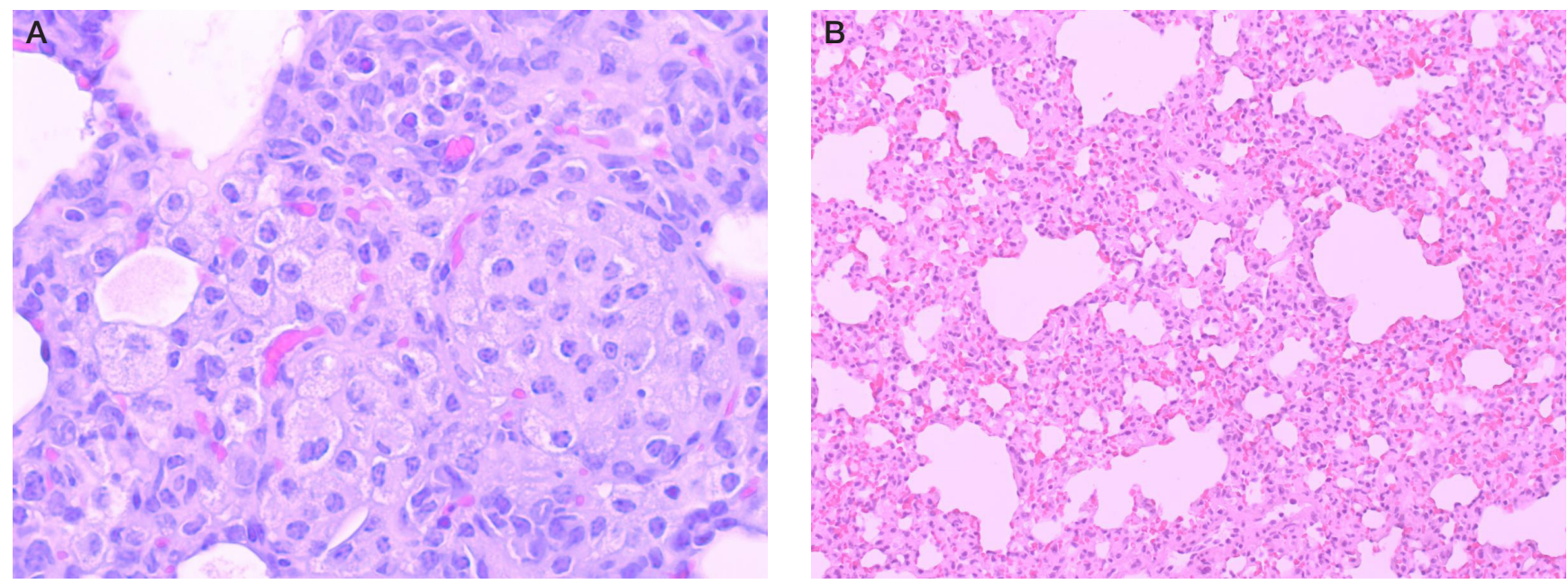

Fig. 4. Lung. Group 3. A. Polymorphic-cell infiltration, reinforced macrophageal response (magnification $\times 650$ ). B. No diffuse alveolar damage in the lungs (staining with hematoxylin and eosin; magnification $\times 200$ )

the exception of two animals, one from group 1 (control), which had pericarditis, and one from group 4, which had pericarditis, myocarditis, spot necrosis and hemorrhage.

Microscopic examination of the spleen revealed that the follicular structures of the white pulp and reactive centers were not changed, and the level of mitosis was same as with the control. In the red pulp of the spleen, there was an accumulation of plasmacytic cells of varying maturity; the degree of severity differed within groups (in two out of five animals in groups 1, 2 and 3 , in three out of five animals in group 4). Plasmacytic cells were detected by histochemical staining with methyl green and pyronine (the Brachet method). In addition, hyperemia with hemorrhage was observed in all groups, with the most pronounced changes registered in groups 2 and 4 .

\section{DISCUSSION}

According to our observations, administration of the APCbased medication to Syrian hamsters under the treatment and prevention protocol makes the course of the disease less severe, the alleviation manifesting in smaller weight loss, which is considered an integral indicator characterizing general condition of the body infected with SARS-CoV-2. The body weight loss trend observed in hamsters receiving APC is probably connected with its stimulating effect on energy metabolism and activation of catabolic processes [15].

The lung mass ratio decrease shows that the edema grows less pronounced, which confirms the previous assumption of the studied drug's decongestant effect revealed on the isolated lungs model [11]. This effect may be the result of the APCbased medication's ability to limit permeability of the bloodair barrier through support of the cells' metabolism by active components of the drug and regulation of the glucose uptake by direct translocation of the GLUT family transporters to plasma membrane, which makes the medication a promising remedy for mitochondrial dysfunction [15].

Pathomorphological examination of the lungs showed that a single intranasal administration of $26 \mu \mathrm{l}$ SARS-CoV-2 solution (virus titer $4 \times 10^{4} \mathrm{TCD}_{50} / \mathrm{ml}$ ) triggered COVID-19 in
Syrian hamsters, the disease manifesting in diffuse alveolar lung damage with vascular lesions, which associates with its early exudative stage [16].

Pathomorphological analysis allowed determining the main criteria for evaluation of the lung preparations: presence of alveolar edema, intraalveolar hemorrhages, hyperplasia, hypertrophy and atypia of type II alveolocytes, proliferation of fibroblasts, lung parenchyma vascular lesions (perivascular edema, infiltrates), thrombi, etc.

The comparative pathomorphological evaluation of the lungs of SARS-CoV-2-infected animals that received APCbased drug under the treatment and prevention protocol (group 3) and group 2 animals (positive control) revealed certain differences in histopathological changes. Group 3 animals had no alveolar edema, atypical and hypertrophied forms of type II alveolocytes, lung parenchyma fibrinization. All animals of this group exhibited reinforced macrophage response, which, most likely, reflects activation of regenerative processes in the lungs.

Pathomorphological analysis of histological preparations of lungs, heart and spleen of group 4 animals (received APCbased drug under the treatment protocol) revealed pulmonary edema, hemorrhages, hypertrophy and atypia of alveolocytes, vascular damage. The nature of the destructive changes identified generally corresponded to that found in group 2 animals.

Administration of the APC under the treatment protocol did not have a significant effect on the course of the infectious process. The established fact corresponds to the literature data on the greater effectiveness of certain pharmacological agents when they are used for COVID-19 prevention rather than therapy, which may be associated with the virulence of SARS-CoV-2, its high replication rate and rapid development of clinical manifestations of the disease $[17,18]$.

\section{CONCLUSIONS}

APC-based drug used as a therapeutic and preventive agent reduces pulmonary edema and makes morphological signs of lung tissue damage less pronounced in male Syrian hamsters infected with SARS-CoV-2. 
1. Zhou P, Yang XL, Wang XG, Hu B, Zhang L, Zhang W. A pneumonia outbreak associated with a new coronavirus of probable bat origin. Nature. 2020; 579: 270-73.

2. Kogan EA, Berezovskij YuS, Procenko DD, Bagdasarjan TR, Grecov EM, Demura SA, i dr. Patologicheskaja anatomija infekcii, vyzvannoj SARS-COV-2. Cudebnaja medicina. 2020; 2: 8-30. Russian.

3. Heinz FX, Stiasny K. Profiles of current COVID-19 vaccines. Wien Klin Wochenschr. 2021; 1-13. DOI: 10.1007/s00508-02101835-w.

4. DeFrancesco L. COVID-19 antibodies on trial. Nat Biotechnol. 2020; 38: 1242-52. DOI: 10.1038/s41587-021-00813-x.

5. Brouwer JM, Caniels TG, Straten K, Snitselaar JL, Aldon $Y$, Bangaru S, et al. Potent neutralizing antibodies from COVID-19 patients define multiple targets of vulnerability. Science. 2020; 369: $643-50$

6. Tortorici A, Beltramello M, Lempp FA, Pinto D, Dang HV, Rosen LE. Ultrapotent human antibodies protect against SARS-CoV-2 challenge via multiple mechanisms. Science. 2020; 370: 950-7. DOI: 10.1126/science.abe3354.

7. Karkischenko VN, Pomytkin IA, Skvortsova VI. The Opioidergic System of Immune Cells: A New Pharmacological Target in the Therapy of "Cytokine Storm". Journal Biomed. 2020; 16 (4): 14 23. Russian.

8. Sia SF, Yan LM, Chin AH, Fung K, Choy KT, Wong AL, et al. Pathogenesis and transmission of SARSCoV-2 in golden hamsters. Nature. 2020; 583 (7818): 834-8. DOI: 10.1038/ s41586-020-2342-5.

9. Imaia M, Iwatsuki-Horimotoa K, Hattab M, Loeberc S, Halfmannb PJ. Syrian hamsters as a small animal model for SARS-CoV-2 infection and countermeasure development. PNAS. 2020; 117 (28): 16587-95. DOI: 10.1073/pnas.2009799117.

10. Chan JF, Zhang AJ, Yuan S, Poon VK, Chan CC, Lee AC, et al. Simulation of the clinical and pathological manifestations of Coronavirus Disease 2019 (COVID-19) in golden Syrian hamster model: implications for disease pathogenesis and transmissibility. Clin Infect Dis. 2020; 71 (9): 2428-46. DOI: 10.1093/cid/ciaa325.

11. LaptevDS, Petunov SG, Nechaykina OV, Bobkov DV, RadilovAS. Using experimental ex vivo models to develop COVID-19 pathogenetic therapy and complications prevention agents. Extreme Medicine. 2020; (4): 6-12. DOI: 10.47183/mes.2020.020. Russian.

12. Reed LJ, Muench $\mathrm{H}$. A simple method of estimating fifty percent endpoints. Am J Hygiene. 1938; 27: 493-7.

13. Rybakova AV, Makarova MN. Sanitarnyj kontrol' jeksperimental'nyh klinik (vivariev) v sootvetstvii s lokal'nymi i mezhdunarodnymi trebovanijami. Mezhdunarodnyj vestnik veterinarii. 2015; 4: 8189. Russian.

14. Nambulli S, Xiang Y, Tilston-Lunel NL, Rennick LJ, Sang Z, Klimstra WB, et al. Inhalable Nanobody (PiN-21) prevents and treats SARS-CoV-2 infections in Syrian hamsters at ultra-low doses. Sci Adv. 2021; 7 (22): eabh0319. DOI: 10.1126/sciadv. abh0319.

15. Barnes $\mathrm{K}$, Ingram JC, Porras $\mathrm{OH}$, Barros LF, Hudson ER, Fryer LG, et al. Activation of GLUT1 by metabolic and osmotic stress: potential involve ment of AMP activated protein kinase. J Cell Sci. 2002; 115: 2433-42.

16. Zabozlaev FG, Kravchenko YeV, Galljamova AR, Letunovskij NN. Patologicheskaja anatomija legkih pri novoj koronavirusnoj infekcii (SOVID-19). Predvaritel'nyj analiz autopsijnyh issledovanij. Klinicheskaja praktika. 2020; 11 (2): 60-76. Russian.

17. Baum BA, Ajithdoss D, Copin R, Zhou A, Lanza K, Negron N, et al. REGN-CoV2 antibodies prevent and treat SARS-CoV-2 infection in rhesus macaques and hamsters. Science. 2020; 370: 1110-5.

18. Hartman AL, Nambulli S, McMillen CM, White AG, TilstonLunel NL, Albe JR, et al. SARS-CoV-2 infection of African green monkeys results in mild respiratory disease discernible by PET/ CT imaging and shedding of infectious virus from both respiratory and gastrointestinal tracts. PLoS Pathog. 2020; 16 (9): e1008903. DOI: 10.1371/journal.ppat.1008903.

\section{Литература}

1. Zhou P, Yang XL, Wang XG, Hu B, Zhang L, Zhang W. A pneumonia outbreak associated with a new coronavirus of probable bat origin. Nature. 2020; 579: 270-73.

2. Коган Е. А., Березовский Ю. С., Проценко Д. Д., Багдасарян Т. Р. Грецов Е. М., Демура С. А. и др. Патологическая анатомия инфекции, вызванной SARS-COV-2. Судебная медицина. 2020; 2: 8-30.

3. Heinz FX. Stiasny K. Profiles of current COVID-19 vaccines. Wien Klin Wochenschr. 2021; 1-13. DOI: 10.1007/s00508-02101835-w.

4. DeFrancesco L. COVID-19 antibodies on trial. Nat Biotechnol. 2020; 38: 1242-52. DOI: 10.1038/s41587-021-00813-x.

5. Brouwer JM, Caniels TG, Straten K, Snitselaar JL, Aldon $Y$, Bangaru S, et al. Potent neutralizing antibodies from COVID-19 patients define multiple targets of vulnerability. Science. 2020; 369: $643-50$

6. Tortorici A, Beltramello M, Lempp FA, Pinto D, Dang HV, Rosen LE Ultrapotent human antibodies protect against SARS-CoV-2 challenge via multiple mechanisms. Science. 2020; 370: 950-7. DOI: 10.1126/science.abe3354.

7. Каркищено В. Н., Помыткин И. А., Скворцова В. И. Опиоидэргическая система иммунных клеток: новая фармакологическая мишень в терапии «цитокинового шторма». Биомедицина. 2020; 16 (4): 14-23.

8. Sia SF, Yan LM, Chin AH, Fung K, Choy KT, Wong AL, et al. Pathogenesis and transmission of SARSCoV-2 in golden hamsters. Nature. 2020; 583 (7818): 834-8. DOI: 10.1038/ s41586-020-2342-5.

9. Imaia M, Iwatsuki-Horimotoa K, Hattab M, Loeberc S, Halfmannb PJ. Syrian hamsters as a small animal model for SARS-CoV-2 infection and countermeasure development. PNAS. 2020; 117
(28): 16587-95. DOI: 10.1073/pnas.2009799117.

10. Chan JF, Zhang AJ, Yuan S, Poon VK, Chan CC, Lee AC, et al. Simulation of the clinical and pathological manifestations of Coronavirus Disease 2019 (COVID-19) in golden Syrian hamster model: implications for disease pathogenesis and transmissibility. Clin Infect Dis. 2020; 71 (9): 2428-46. DOI: 10.1093/cid/ciaa325.

11. Лаптев Д. С., Петунов С. Г., Нечайкина О. В., Бобков Д. В., Радилов А. С. Использование экспериментальных моделей ex vivo для разработки средств патогенетической терапии и профилактики осложнений COVID-19. Медицина экстремальных ситуаций. 2020; 22 (4): 6-13. DOI: 10.47183/mes.2020.020.

12. Reed LJ, Muench $\mathrm{H}$. A simple method of estimating fifty percent endpoints. Am J Hygiene. 1938; 27: 493-7.

13. Рыбакова А. В., Макарова М. Н. Санитарный контроль экспериментальных клиник (вивариев) в соответствии с локальными и международными требованиями. Международный вестник ветеринарии. 2015; 4: 81-89.

14. Nambulli S, Xiang Y, Tilston-Lunel NL, Rennick LJ, Sang Z, Klimstra WB, et al. Inhalable Nanobody (PiN-21) prevents and treats SARS-CoV-2 infections in Syrian hamsters at ultra-low doses. Sci Adv. 2021; 7 (22): eabh0319. DOI: 10.1126/sciadv. abh0319.

15. Barnes K, Ingram JC, Porras $\mathrm{OH}$, Barros LF, Hudson ER, Fryer LG, et al. Activation of GLUT1 by metabolic and osmotic stress: potential involve ment of AMP activated protein kinase. J Cell Sci. 2002; 115: 2433-42.

16. Забозлаев Ф. Г., Кравченко Э. В., Галлямова А. Р., Летуновский Н. Н. Патологическая анатомия легких при новой коронавирусной инфекции (COVID-19). Предварительный анализ аутопсийных исследований. Клиническая практика. 2020; 11 (2): 60-76. 
17. Baum BA, Ajithdoss D, Copin R, Zhou A, Lanza K, Negron N, et al. REGN-CoV2 antibodies prevent and treat SARS-CoV-2 infection in rhesus macaques and hamsters. Science. 2020; 370: 1110-5.

18. Hartman AL, Nambulli S, McMillen CM, White AG, Tilston-
Lunel NL, Albe JR, et al. SARS-CoV-2 infection of African green monkeys results in mild respiratory disease discernible by PET/ CT imaging and shedding of infectious virus from both respiratory and gastrointestinal tracts. PLoS Pathog. 2020; 16 (9): e1008903. DOI: 10.1371/journal.ppat.1008903. 


\section{REHABILITATION IN ONCOLOGY}

Kamilova TA ${ }^{1}$, Golota $\mathrm{AS}^{1}{ }^{\otimes}$, Vologzhanin $\mathrm{DA}^{1,2}$, Shneider OV${ }^{1}$, Scherbak $\mathrm{SG}^{1,2}$

1 Saint Petersburg City Hospital № 40, Saint Petersburg, Russia

2 Saint-Petersburg State University, Saint Petersburg, Russia

Current oncology and oncohematology treatment methods allow more patients to successfully survive the disease. However, afterwards, most survivors have to deal with a wide range of symptoms and side effects and need rehabilitation. Personalized rehabilitation programs for such patients employ various methods of physical medicine. Physical activity is an important component of the cancer patients' treatment and rehabilitation. It improves their functional health, specifically physical performance, cognitive function, psychological health, and makes the quality of their lives better. Physical activity increases muscle strength, alleviates the radiation and chemotherapy side effects and relieves fatigue. Personalized exercise programs are employed to monitor patient's condition and exercise tolerance. Physical and cognitive rehabilitative interventions are performed simultaneously as part of interdisciplinary rehabilitative care, so this approach can have a synergistic effect. It is necessary to factor in contraindications when prescribing regular physical activity, exercise and other methods of rehabilitation, otherwise they can lead to clinical complications.

Keywords: cancer, oncology disease, rehabilitation, physical activity, quality of life, muscle strength, fatigue, physical exercises.

Author contribution: Kamilova TA — search and analysis, article text authoring; Golota AS — search and analysis, article text discussion and editing; Vologzhanin DA — article text discussion and editing; Schneider OV, Shcherbak SG — concept development, article discussion; all authors made a significant contribution to concept development and article preparation, they have read and approved the final version thereof before publication.

$\triangle$ Correspondence should be addressed: Alexander S. Golota

Borisova, 9 B, St. Petersburg, 197706; golotaa@yahoo.com

Received: 29.05.2021 Accepted: 12.06.2021 Published online: 21.06.2021

DOI: $10.47183 /$ mes.2021.013

\section{РЕАБИЛИТАЦИЯ В ОНКОЛОГИИ}

Т. А. Камилова ${ }^{1}$, А. С. Голота ${ }^{1}$, Д. А. Вологжанин ${ }^{1,2}$, О.В.Шнейдер ${ }^{1}$, С. Г. Щербак ${ }^{1,2}$

${ }^{1}$ Городская больница № 40, Санкт-Петербург, Россия

${ }^{2}$ Санкт-Петербургский государственный университет, Санкт-Петербург, Россия

Современное лечение онкологических и онкогематологических заболеваний приводит к повышению выживаемости пациентов. Однако большинство выживших пациентов сталкиваются с широким спектром симптомов и побочных эффектов и нуждаются в реабилитации. Индивидуальные программы реабилитации таких больных включают в себя различные методы физической медицины. Физическая активность является важным компонентом в лечении и реабилитации больных онкологическими заболеваниями и улучшает их функциональное здоровье в отношении физической работоспособности, когнитивных функций, психологического здоровья и качества жизни. Физическая активность увеличивает мышечную силу, уменьшает побочные эффекты лучевой и химиотерапии и снижает утомляемость. Для контроля состояния пациента и толерантности к физическим нагрузкам используют индивидуально адаптированные программы физических упражнений. Реабилитационные вмешательства физической и когнитивной направленности выполняются одновременно в рамках междисциплинарной реабилитационной помощи, поэтому такой подход может иметь синергетический эффект. Регулярные физические нагрузки, упражнения и другие методы реабилитации необходимо применять с учетом противопоказаний, в противном случае они могут привести к клиническим осложнениям.

Ключевые слова: рак, онкологическое заболевание, реабилитация, физическая активность, качество жизни, мышечная сила, утомляемость, физические упражнения

Вклад авторов: Т. А. Камилова - поисково-аналитическая работа, написание текста статьи; А. С. Голота - поисково-аналитическая работа, обсуждение и редактирование текста статьи; Д. А. Вологжанин - обсуждение и редактирование текста статьи; О. В. Шнейдер, С. Г. Щербак разработка концепции, обсуждение статьи; все авторы внесли существенный вклад в разработку концепции, подготовку статьи, прочли и одобрили финальную версию перед публикацией.

$\triangle$ Для корреспонденции: Александр Сергеевич Голота ул. Борисова, д. 9 Б, г. Санкт-Петербург, 197706; golotaa@yahoo.com

Статья получена: 29.05.2021 Статья принята к печати: 12.06.2021 Опубликована онлайн: 21.06.2021

DOI: $10.47183 /$ mes.2021.013

The term "cancer survivor" dates back to the 1980s, but today the numbers of cancer survivors are growing almost exponentially. Many people who have had cancer experience difficulties in their daily life, as about $50 \%$ of them suffer one or more concomitant chronic diseases caused by cancer or its treatment. Some late symptoms may be caused by surgery, radiation therapy, or chemotherapy. In this connection, the number of studies dedicated to rehabilitation of cancer patients is growing, with some of them covering pre-surgery rehabilitation aimed at raising the chances of survival $[1,2]$. Regular physical activity is an important component of rehabilitation of such patients: it improves their functional state, physical performance, mental health and quality of life. It is imperative to minimize the functional impairments and disabilities that such people have to deal with during and after the treatment, and to promote their reintegration into society. This goal requires a coordinated team of physiotherapists, physical therapists and occupational therapists who are familiar with the unique needs of this patient group.

Cancer patients should be informed about rehabilitation, especially about physical therapy (exercise therapy), from the moment of diagnosis. Understanding the vital importance of ability to work, cancer survivors are highly motivated to return to their jobs, since many of them are able and willing to work [3].

\section{Rehabilitation in pain management. Exercise therapy}

Debilitating pain is one of the most common and persistent problems faced by cancer patients and cancer survivors, 
with 55\% of them experiencing it during treatment and $40 \%$ thereafter. Currently, pharmacotherapy is the standard approach to cancer pain management. Both patients and many healthcare providers are unaware of the potential benefits of rehabilitation in managing pain during and after cancer treatment. Rehabilitation of cancer patients relies on interdisciplinary cooperation aimed at functional optimization and pain relief. Accurate diagnosis of pain is a critical step in clinical decision making [4]. Sensitization of the central nervous system is added to the primary causes of pain. In this case, the pain is associated not with tissue damage but with altered pain modulation that generates nocyplastic pain (pain arising from altered nociception), which can alter the response to both specific and general exercise therapy. Adaptation of rehabilitation methods to the prevailing mechanism of pain can increase their effect. The rehabilitation methods, including manual therapy, specific and general exercise therapy, must be applied as part of an interdisciplinary approach to pain management, taking into account the nature of the pain and proper assessment of the results. Individual exercise therapy programs differ in content (exercises for mobilization, stretching, muscle strengthening) and duration (time, frequency and intensity). Manual therapy research in oncology addresses passive joint mobilization and massage therapy. Passive manual mobilization is primarily aimed at restoring the range of motion of the joint. The pain can be relieved through activation of mechanoreceptors and stimulation of fast-conducting nerve fibers. One of the studies has shown the beneficial effect passive mobilization has on the long-term prevalence of locoregional pain when done during the first week after surgery [5].

Physical activity diminishes the side effects of treatment reduces the risk of recurrence of cancer and concomitant cardio-metabolic diseases. Based on the results of three summits that discussed the role of physical therapy, the involvement of physical therapists in solving the problems of noncommunicable diseases, including cancer, has been declared an urgent professional priority [6]. A summary of 53 systematic reviews covering exercise therapy prescribed to populations of cancer patients showed that exercising is beneficial before, during and after treatment of all types of cancer, and it is safe to exercise at any stage of the disease [7]. Personalized exercise programs are employed to control patient's condition and capability to exercise [8]. Fatigability is often associated with pain (and vice versa) and can interfere with regular general exercising. Some cancer treatments have toxic effects on the cardiovascular system, resulting in decreased exercise tolerance. This must be taken into account when compiling an exercise program; ideally, the patient should receive treatment from an interdisciplinary team addressing stress, anxiety and sleep disturbances [9].

A meta-analysis of randomized clinical trials (RCTs) conducted using the European Organization for Research and Treatment of Cancer Questionnaire C30 (EORTC-QLQ-C30) [10] showed that cancer patients and cancer survivors who performed aerobic and/or resistance exercises had the pain significantly less intense. A Cochrane Review summarizes the beneficial effects of general physical activity, including aerobic exercise therapy, resistance training and occupational therapy [11]. The mentioned reviews failed to identify the type of exercise therapy and the specific methods that are most effective for pain relief. The response to exercise varies among patients suffering chronic musculoskeletal pain; it may even lead to hyperalgesia [12]. For arthralgia associated with hormone therapy, which affects up to $50 \%$ of breast cancer (BC) survivors, a combination of aerobic training and muscle strengthening exercises is recommended [13]. A high-quality RCT has shown that 150 weekly minutes of aerobic exercising and strength training can lead to clinically significant pain relief in these patients [14]. Aerobic exercise can neutralize many of the side effects of anticancer therapy and reduce mortality from all types of cancer by increasing the maximum oxygen consumption $\left(\mathrm{VO}_{2}\right.$ max) [8]. Pilates has been included in many rehabilitation practices: it is statistically more effective than other interventions for reducing pain in BC patients [15]. Yoga is also gaining popularity as part of the cancer patients rehabilitation programs, as reflected in a review of 29 RCTs [16]. The authors of this review report exercising improves overall quality of life and reduces fatigue and stress.

The biological mechanism behind the capacity of exercising to reduce mortality and improve overall health is an area of research that is still in its infancy. Changing levels of blood and urine biomarkers associated with cancer can be a manifestation of the beneficial effects of exercise therapy. Such biomarkers enable investigations of the specific physiology and mechanisms through which exercising affects relapse occurrence and cancer progression. According to the results of the analysis of 15 studies (including 12 RCTs) dedicated to blood and urine physical activity biomarkers sampled from cancer survivors [17], moderate intensity exercise therapy (70-85\% of the maximum heart rate and/or 11-13 points on the Borg Scale Rating of Perceived Exertion) has a significant effect on some biomarkers: fasting insulin concentration either decreased or remained relatively stable, but increased in untrained patients; insulin resistance decreased post-exercise with no change in control; the levels of IGFI (insulin like growth factor I), IGFII and IGFBP3 (insulin like growth factor binding protein 3) decreased after 6 months of training and increased in the control group, which translated into a significant difference between the groups. Control group showed growing leptin levels, which went down after exercising. Serum osteocalcin levels remained stable after post-exercise but increased in the control group.

Restrictions in daily activities are associated with increased toxicity of chemotherapy, decreased ability to complete treatment, and decreased overall survival. An RCT studied the effect of outpatient occupational/physical therapy (OT/PT) program developed for elderly functionally impaired cancer patients (65-92 years old) on their functional state [18]; the report states that the OT/PT group participants' social acting, physical functioning and aspiration to activity has increased significantly. Occupational therapy reduces stress in cancer patients, which allows better coping with psychosocial problems and improves functioning.

Thus, exercise therapy is safe and well tolerated by cancer patients both during and after treatment. However, the available data indicate that its analgesic effect is weak.

\section{Breast cancer}

The five-year survival rate for non-metastatic BC exceeds $84 \%$ [19]. However, most BC survivors suffer the consequences of the disease or its treatment: pain, decreased arm muscle strength, lymphedema, chronic fatigue and depression, cachexia, decreased lung capacity and range of motion, decreased health-related quality of life (HRQOL), as well as psychosocial consequences, such as stress and reduced social interactions, functional activity and life roles [20]. The loss of muscle mass and decreased performance capability typical of BC patients translate into passivity and deterioration in health. Therefore, post-surgery rehabilitation gets more attention nowadays. 
Patients who exercise before, during, and after BC treatment are more likely to return to work. Low-intensity aerobic training twice a week is well tolerated even by patients undergoing concurrent radiation or chemotherapy [21, 22].

Breast cancer survivors usually avoid using the affected arm, which worsens the physical condition and should be compensated for by strength exercises, since the loss of muscle mass increases the risk of metabolic and cardiovascular diseases [23]. A workout program helped increase muscle strength by $20 \%$ and reduce perceived fatigue, as well as improve physical, role-related, emotional and social functioning. At the same time, the program while reducing side effects experienced during and after cancer treatments. Results from RCTs support the benefits of starting exercise as early as possible. Training loads induces beneficial responses in other tissues, such as bone. This is especially important for BC patients, who have bone density below normal. Strength training helps prevent further bone loss. Authors of the study recommend including high-intensity strength training sessions in the BC patient rehabilitation programs, such rehabilitation subject to careful examination and monitoring of patients [19].

Breast cancer survivors suffer from shortness of breath and low exercise tolerance. The involvement of lymph nodes drastically reduces the peak expiratory flow rate. Respiratory physical therapy is the main method for preventing these complications. Pulmonary rehabilitation, early mobilization and sputum clearance from the airways have a positive effect on symptoms associated with respiratory complications and improve lung function in $\mathrm{BC}$ patients. The effectiveness of physical therapy in restoring lung function after BC treatment is especially apparent in patients with cancer at advanced stages [24].

\section{Lung cancer}

In oncology, pulmonary rehabilitation (PR) is an interdisciplinary complex treatment aimed at improving postoperative results and alleviating complications in patients that received radiation or chemotherapy [25].

Patients with inoperable lung cancer often have low physical status, low exercise tolerance and are physically passive. A clinical trial of an eight-week at-home PR program designed for lung cancer patients treated non-surgically that implies gradual increase of physical activity has shown that rehabilitation can mitigate the afore conditions and increase the likelihood of successful completion of active lung cancer therapy [26]. A Cochrane review dedicated to rehabilitation/exercise therapy for patients with advanced, inoperable lung cancer supports these findings [27].

The European Society of Thoracic Surgeons' Guidelines for Recovery from Lung Surgery recommend prehabilitation for patients with borderline lung function or reduced exercise tolerance [28].

Patients undergoing chemotherapy for lung cancer or malignant pleural mesothelioma completed an eight-week athome PR program that combined exercise with therapeutic education and psychosocial management. These patients were educated to recognize the dyspnea threshold and advised to do the daily 30-45 minute exercise program at least 5 days a week. The program included endurance training on a bicycle ergometer, muscle strengthening exercises with weights (dumbbells) and elastic resistance bands, walking and stairs climbing. There were no PR side effects observed. The physical activity and anxiety scores improved significantly. Post-PR reevaluation showed a correlation of these results with the somatic status of the patients [29].
A meta-analysis that included 15 RCTs (870 participants in total) studying the effect of breathing exercises on dyspnea, sixminute walking distance, anxiety and depression in lung cancer patients shows a positive effect of such exercises on dyspnea and the six-minute test results, especially post-surgery. The authors propose to introduce breathing exercises into routine clinical practice [30]. The increased long-term survival of lung cancer patients and other benefits of PR prompted the Australian Society of Clinical Oncology to issue the official position that all lung cancer patients should be prescribed exercise as part of standard therapy [31].

\section{Hematologic malignancies}

The conditions peculiar to hematologic malignancy $(\mathrm{HM})$ patients are cytopenia, nausea, vomiting, anorexia, loss of energy, anxiety and depression associated with muscle dysfunction, loss of muscle mass and decreased muscle strength. These symptoms can lead to decreased physical activity and development of the disuse syndrome [32]. A crosssectional, observational study aimed to identify the factors influencing muscle function in HM inpatients; the results of this study show that a rehabilitation intervention designed to increase physical activity and improve the nutritional status (diet therapy) should be considered necessary in the context of improvement of muscle function in HM patients [33].

Lymphoma survivors usually complain of long-term and late side effects of treatment, such as chronic fatigue, pain, muscle weakness, neuropathy, anxiety, depression and deteriorating functionality and quality of life [34-36]. Programs that include exercise and relaxation have a positive effect on and relieve these symptoms. In the context of the Relaxation and Exercise In Lymphoma study, patients practiced a 12-week at-home rehabilitation program [37]. For the majority of lymphoma patients (86\%), at-home rehabilitation after chemotherapy was a positive experience that facilitated recovery. Thus, posttreatment rehabilitation programs designed for $\mathrm{HM}$ patients should include observation, motivation building, exercise therapy and healthy lifestyle recommendations.

\section{Abdominal cancer}

Surgery combined with radiation and/or chemotherapy is the standard approach to abdominal cancers. Malnutrition, decreased physical activity and pain increase the risk of suboptimal healing after surgery. In addition, $70 \%$ of colorectal cancer patients, $10-79 \%$ of prostate cancer patients, $42-70 \%$ of pelvic cancer patients experience symptoms of dysfunctions of pelvic floor (bladder, intestine and reproductive organs) after surgery. To learn the feasibility of interdisciplinary approach to rehabilitation of patients who underwent surgery for abdominopelvic cancer, there was designed a study investigating functional disorders, symptoms of pelvic floor muscle dysfunction, changes in muscle strength and physical activity, anxiety, depression and HRQOL before the rehabilitation and 8 weeks and 6 months thereafter [38].

After surgery for stage I-III colorectal, gynecological or prostate cancer, patients underwent an eight-week training program under the supervision of a physical therapist, physiologist, psychologist and nutritionist. Post-rehabilitation, there were clinically and statistically significant changes identified. The patients' exercise capacity improved, bowel symptoms and depression faded, HRQOL increased immediately after the program was completed and remained at the achieved level after 6 months. Exercise therapy for the 
pelvic diaphragm muscles increases their contractility and improves sphincter control. Thus, oncologic rehabilitation should be considered an integral component of standard care protocols applied in abdominal and pelvic cancer cases [38].

\section{Cancer cachexia and muscle atrophy}

Cancer cachexia causes muscle atrophy and loss of body weight, which accelerates the progression of cancer, worsens treatment outcomes, and decreases chances of survival. Complex treatments, including physical therapy, are used to counteract muscle atrophy. Different types of exercise have different effects: for example, endurance training stimulates oxidative metabolism but does not increase the in muscle mass significantly, whereas resistance exercises lead to muscle hypertrophy. Moderate load resistance exercises are used to prevent muscle atrophy. As the muscle mass decreases, there occurs a structural shift from slow-twitch muscle fibers to fast-twitch muscle fibers. To induce muscle hypertrophy, the magnitude of the load is critical: moderate load training will stimulate only the slow-twitch fibers and not fast-twitch fibers. The decrease in the mass of fatigue-resistant slow-twitch fibers is partly responsible for the exercise intolerance and fatigue often observed in cancer patients. This means that, if the patient's physical condition allows, it is beneficial to advise higher load exercise in order to slow down muscle loss [39].

\section{Rehabilitation of cancer patients: organizational aspects}

Most cancer survivors prefer exercising at home with coordination done by the cancer center's exercise therapy specialists. Regular monitoring of how the patients follow the exercise program promotes a lasting change in their behavior (increases adherence to treatment and recommendations) Thus, rehabilitation in the cancer center followed by the prescribed at-home exercising monitored regularly may be a preferable model of exercise therapy rehabilitation of cancer patients that is further enhanced by a continued information exchange between oncologists and exercise therapy specialists and prompt communication of the treatment results to the medical team. Based on these principles, Canadian rehabilitation therapists have developed and implemented a clinically integrated program "Wellness and Exercise for Cancer Survivors" for patients of a major cancer center. This program capitalizes on the upsides of the in-hospital and athome rehabilitation models, with "home" refers to a variety of exercise environments, including fitness centers and outdoor activities. The program, innovative in its structure, demonstrated the central role of the cancer center in providing supportive care to patients in need thereof. The participants could attend weekly group sessions to practice the exercise technique. For independent exercise, they received a detailed program guidance, resistance bands and gymnastic balls. Follow-ups to reevaluate and adapt the exercise program were scheduled 6, 12, 24, and 48 weeks after the initial examination and exercising prescription. Despite a significant dropout rate, the cancer rehabilitation program showed clinically significant improvements of the functional status and was highly praised by the participants. The functional capabilities and quality of life indicators improved over 6 weeks and increased or persisted for 48 weeks [40].

Currently, there is no standardized curriculum for cancer patient rehabilitation specialists. They are trained mainly through mentoring and at the conferences held by national professional societies, the role of which is extremely important. Palliative care and pain management training programs are an alternative thereto. Although most cancer rehabilitation professionals do not prescribe opiates to their patients, leaving it to palliative care specialists, opiate prescribing guidelines are an important component of cancer rehabilitation curricula [41].

Another discussed topic was the need for information, in particular for dietary advice. A survey of 230 cancer survivors showed that $98 \%$ of the respondents would like to receive additional information after treatment. Upon completion thereof, patients are more likely to find cancer-related information on their own than learn it from medical personnel [35]. Cancer survivors must be allowed a constant contact with health professionals (including via online means of communication) and advice on healthy nutrition and lifestyle [42].

\section{CONCLUSION}

Rehabilitation of cancer patients is a new field that aims to help cancer survivors maintain the best possible physical, social, psychological and professional functioning. It consists of many components, including physiotherapy, physical therapy, occupational therapy, speech pathology treatment, neuropsychological and cognitive rehabilitation, lymphedema and pelvic floor therapy. Although cancer rehabilitation is recognized as an important component of high quality cancer care, most cancer survivors find it problematic to gain access thereto. The time has come, and the medical community has started working on changing this reality [43]. It is important that clinicians were not only aware of the disorders that can arise with the appearance of a malignant tumor or its treatment, but also knew how to apply the principles of rehabilitation in these patients [44]. Physical therapists play an important role in the ongoing care for cancer survivors. Currently, there are five cancer patient rehabilitation training programs offered in the US [45].

The modern concept of cancer treatment integrates rehabilitation procedures throughout, from the diagnosis stage to the observation of surviving patients, enabling control over the expected decline in functional status associated with anticancer therapy. Insufficient awareness of the longterm needs of this category of patients and the benefits of rehabilitation is an important problem in clinical practice [18]. The transformation of the rehabilitation of cancer patients into a standard component of therapy will require considerable effort and perseverance. Although the efficacy of rehabilitation exercise therapy has been generally proven, more research is needed to address its safety in patients with heart failure caused by chemotherapy [46].

\section{References}

1. Minnella EM, Liberman AS, Charlebois P, et al. The impact of improved functional capacity before surgery on postoperative complications: a study in colorectal cancer. Acta Oncol. 2019; 58 (5): 573-8. DOI: 10.1080/0284186X.2018.1557343.

2. West MA, Astin R, Moyses HE, et al. Exercise prehabilitation may lead to augmented tumor regression following neoadjuvant chemoradiotherapy in locally advanced rectal cancer. Acta Oncol. 2019; 58 (5): 588-95. DOI: 10.1080/0284186X.2019.1566775. 
3. Cenik F, Mähr B, Palma S, et al. Role of physical medicine for cancer rehabilitation and return to work under the premise of the "Wiedereingliederungsteilzeitgesetz". Wien Klin Wochenschr. 2019 Oct; 131 (19-20): 455-61. DOI: 10.1007/s00508-019-1504-7.

4. Chimenti RL, Frey-Law LA, Sluka KA. A mechanism-based approach to physical therapist management of pain. Phys Ther. 2018; 98 (5): 302-14. DOI: 10.1093/ptj/pzy030.

5. De Groef A, Penen F, Dams L, et al. Best-evidence rehabilitation for chronic pain part 2: pain during and after cancer treatment. J Clin Med. 2019 Jul 5; 8 (7):979. DOI: 10.3390/jcm8070979.

6. Dean E, Skinner M, Myezwa $H$, et al. Health competency standards in physical therapist practice. Phys Ther. 2019; 99 (9): 1242-54. DOI: 10.1093/ptj/pzz087.

7. Stout NL, Baima J, Swisher AK, et al. Systematic review of exercise systematic reviews in the cancer literature (2005-2017). PM R. 2017; 9 (9S2): 347-84. DOI: 10.1016/j.pmrj.2017.07.074.

8. Keilani M, Kainberger F, Pataraia A, et al. Typical aspects in the rehabilitation of cancer patients suffering from metastatic bone disease or multiple myeloma. Wien Klin Wochenschr. 2019; 131 (21-22): 567-75. DOI: 10.1007/s00508-019-1524-3.

9. Ciuca A, Baban A. Psychological factors and psychosocial interventions for cancer related pain. Rom J Intern Med. 2017; 55 (2): 63-68. DOI: 10.1515/rijm-2017-0010.

10. Nakano J, Hashizume K, Fukushima T, et al. Effects of aerobic and resistance exercises on physical symptoms in cancer patients: a meta-analysis. Integr. Cancer Ther. 2018; 17 (4): 1048-58. DOl: 10.1177/1534735418807555.

11. Lahart IM, Metsios GS, Nevill AM, Carmichael AR. Physical activity for women with breast cancer after adjuvant therapy. Cochrane Database of Systematic Rev. 2018 Jan 29; 1 (1): CD011292. DOI: 10.1002/14651858.CD011292.pub2.

12. Rice D, Nijs J, Kosek E, et al. Exercise induced hypoalgesia in pain-free and chronic pain populations: State of the art and future directions. J Pain. 2019 Nov; 20 (11): 1249-66. pii: S15265900(18)30456-5. DOI: 10.1016/j.jpain.2019.03.005.

13. Nahm N, Mee S, Marx G. Efficacy of management strategies for aromatase inhibitor-induced arthralgia in breast cancer patients: $\mathrm{A}$ systematic review. Asian Pac J Clin Oncol. 2018; 14 (6): 374-82. DOI: 10.1111/ajco.12845.

14. Irwin ML, Cartmel B, Gross CP, et al. Randomized exercise trial of aromatase inhibitor-induced arthralgia in breast cancer survivors. J Clin Oncol. 2015; 33 (10): 1104-11. DOI: 10.1200/ JCO.2014.57.1547.

15. Pinto-Carral A, Molina AJ, de Pedro A, Ayan C. Pilates for women with breast cancer: A systematicreview and meta-analysis. Complementary Ther Med. 2018; 41: 130-40. DOI: 10.1016/j. ctim.2018.09.011.

16. Danhauer SC, Addington EL, Cohen L, et al. Yoga for symptom management in oncology: A review of the evidence base and future directions for research. Cancer. 2019; 125 (12): 1979-89. DOI: 10.1002/cncr.31979.

17. McDermott LA, Murphy MH, McNeilly AM, et al. Biological markers as an outcome measure of exercise in cancer rehabilitation: A systematic review. J Cancer Res Ther. 2018; 14 (2): 267-77. DOI: 10.4103/0973-1482.191036.

18. Pergolotti M, Deal AM, Williams GR, et al. Older adults with cancer: a randomized controlled trial of occupational and physical therapy. J Am Geriatr Soc. 2019; 67 (5): 953-60. DOI: 10.1111/ jgs. 15930.

19. Cešeiko R, Eglïtis J, Srebnijs A, et al. The impact of maximal strength training on quality of life among women with breast cancer undergoing treatment. Exp Oncol. 2019; 41 (2): 166-72. DOI: 10.32471/exp-oncology.2312-8852.vol-41-no-2.13249.

20. Schulz SVW, Laszlo R, Otto S, et al. Feasibility and effects of a combined adjuvant high-intensity interval/strength training in breast cancer patients: a single-center pilot study. Disabil Rehabil. 2018; 40 (13): 1501-08. DOI: 10.1080/09638288.2017.1300688.

21. Mirandola D, Miccinesi G, Muraca MG, et al. Longitudinal assessment of the impact of adapted physical activity on upper limb disability and quality of life in breast cancer survivors from an Italian cohort. Support Care Cancer. 2018; 26 (2): 329-32. DOI: 10.1007/s00520-017-3930-2.

22. Paolucci $\mathrm{T}$, Bernetti $\mathrm{A}$, Paoloni $\mathrm{M}$, et al. Therapeutic alliance in a single versus group rehabilitative setting after breast cancer surgery: psychological profile and performance rehabilitation. Biores Open Access. 2019; 8 (1): 101-10. DOI: 10.1089/ biores.2019.0011.

23. Travier N, Buckland G, Vendrell JJ, et al. Changes in metabolic risk, insulin resistance, leptin and adiponectin following a lifestyle intervention in overweight and obese breast cancer survivors. Eur J Cancer Care. 2018; 27 (4): e12861. DOI: 10.1111/ecc.12861.

24. Kulik-Parobczy I. Evaluation of the effectiveness of physiotherapy in patients after oncological breast cancer treatment based on spirometric indicators. Contemp Oncol (Pozn). 2019; 23 (1): 4751. DOI: 10.5114/wo.2019.82929.

25. Janssen SMJ, Abbink JJ, Lindeboom R, Vliet Vlieland TPM. Outcomes of pulmonary rehabilitation after treatment for nonsmall cell lung cancer stages I to Illa: an observational study. J Cardiopulm Rehabil Prev. 2017; 37 (1): 65-71. DOI: 10.1097/ HCR.0000000000000227.

26. Edbrooke L, Aranda S, Granger CL, et al. Multidisciplinary homebased rehabilitation in inoperable lung cancer: a randomised controlled trial. Thorax. 2019; 74 (8): 787-96. DOI:10.1136/ thoraxinl-2018-212996.

27. Peddle-Mclntyre CJ, Singh F, Thomas R, et al. Exercise training for advanced lung cancer. Cochrane Database Syst Rev. 2019; 2 (2): CD012685. DOI: 10.1002/14651858.CD012685.pub2.

28. Batchelor TJP, Rasburn NJ, Abdelnour-Berchtold E, et al. Guidelines for enhanced recovery after lung surgery: recommendations of the enhanced recovery after surgery (ERASVR ) society and the European Society of Thoracic Surgeons (ESTS). Eur J Cardiothorac Surg. 2019; 55 (1): 91-115. DOI: 10.1093/ejcts/ezy301.

29. Olivier C, Grosbois JM, Cortot AB, et al. Real-life feasibility of home-based pulmonary rehabilitation in chemotherapy-treated patients with thoracic cancers: a pilot study. BMC Cancer. 2018; 18 (1): 178. DOI: 10.1186/s12885-018-4102-6.

30. Liu X, Wang YQ, Xie J. Effects of breathing exercises on patients with lung cancer. Oncol Nurs Forum. 2019; 46 (3): 303-17. DOI: 10.1188/19.ONF.303-317.

31. Steiner MC. Should pulmonary rehabilitation be a standard of care in lung cancer? Thorax. 2019; 74 (8): 725-6. DOI: 10.1136/ thoraxinl-2019-213157.

32. Da Silva JR Jr, Wiegert EVM, Oliveira L, Calixto-Lima L. Different methods for diagnosis of sarcopenia and its association with nutritional status and survival in patients with advanced cancer in palliative care. Nutrition. 2018; 60: 48-52. DOI: 10.1016/j. nut.2018.09.003.

33. Fukushima T, Nakano J, Ishii $\mathrm{S}$, et al. Factors associated with muscle function in patients with hematologic malignancies undergoing chemotherapy. Support Care Cancer. 2020 Mar; 28 (3): 1433-9. DOI: 10.1007/s00520-019-04955-2.

34. Damlaj M, El Fakih R, Hashmi SK. Evolution of survivorship in lymphoma, myeloma and leukemia: Metamorphosis of the feld into long term follow-up care. Blood Rev. 2019; 3: 63-73. DOl: 10.1016/j.blre.2018.07.003.

35. Hackett F, Dowling M. Lymphoma survivors' experiences at the end of treatment. J Clin Nurs. 2019; 28 (3-4): 400-9. DOI: 10.1111/jocn.14658.

36. Raphael D, Frey R, Gott M. Maintaining psychosocial wellbeing for post-treatment haematological cancer survivors: Strategies and potential barriers. Eur J Oncol Nurs. 2019; 38: 36-41. DOI: 10.1016/j.ejon.2018.11.011.

37. Hathiramani S, Pettengell R, Moir $\mathrm{H}$, Younis A. Relaxation and exercise in lymphoma survivors (REIL study). BMC Sports Sci Med Rehabil. 2019; 11: 17. DOI: 10.1186/s13102-019-0127-7.

38. Frawley HC, Lin KY, Granger CL, et al. An allied health rehabilitation program for patients following surgery for abdomino-pelvic cancer: a feasibility and pilot clinical study. Support Care Cancer. 2020 Mar; 28 (3): 1335-50. DOI: 10.1007/s00520-019-04931-w.

39. Hegedus A, Trzaskoma L, Soldos P, et al. Adaptation of fatigue affected changes in muscle EMG frequency characteristics for the determination of training load in physical therapy for cancer patients. Pathol Oncol Res. 2020 Apr; 26 (2): 1129-35. DOI: 10.1007/s12253-019-00668-3.

40. Santa Mina D, Au D, Auger LE, et al. Development, implementation, 
and effects of a cancer center's exercise-oncology program. Cancer. 2019; 125 (19): 3437-47. DOI: 10.1002/cncr.32297.

41. Sharma R, Molinares-Mejia D, Khanna A, et al. Training and practice patterns in cancer rehabilitation: a survey of physiatrists specializing in oncology care. Phys Med Rehab. 2020 Feb; 12 (2): 180-5. DOI: 10.1002/pmrj.12196.

42. Hathiramani S, Pettengell R, Moir H, Younis A. Lymphoma survivors' experience of participation in a home-based intervention post-chemotherapy. Qual Life Res. 2019 Nov; 28 (11): 2951-5. DOI: 10.1007/s11136-019-02244-3.

43. Stubblefield MD, Kendig TD, Khanna A. ReVitalizing cancer survivors - making cancer rehabilitation the standard of care.
MD Advis. Spring 2019; 12 (2): 30-33.

44. Stout NL, Silver JK, Alfano CM, et al. Long-term survivorship care after cancer treatment: a new emphasis on the role of rehabilitation services. Phys Ther. 2019; 99 (1): 10-13. DOI: 10.1093/ptj/pzy115.

45. Yadav RR, Ngo-Huang AT, Ng A, et al. Characteristics of cancer rehabilitation fellowship training programs in the USA. J Cancer Educ. 2018; 33 (6): 1364-7. DOI: 10.1007/s13187-018-1371-3.

46. Hutchison N, Deval N, Rabusch S, et al. Physical therapy based exercise protocol for cancer patients: Evaluating outcomes for cardiopulmonary performance and cancer-related fatigue. PM R. 2019 Feb 6. DOI: 10.1002/pmrj.12128.

\section{Литература}

1. Minnella EM, Liberman AS, Charlebois P, et al. The impact of improved functional capacity before surgery on postoperative complications: a study in colorectal cancer. Acta Oncol. 2019; 58 (5): 573-8. DOI: 10.1080/0284186X.2018.1557343.

2. West MA, Astin R, Moyses HE, et al. Exercise prehabilitation may lead to augmented tumor regression following neoadjuvant chemoradiotherapy in locally advanced rectal cancer. Acta Oncol. 2019; 58 (5): 588-95. DOI: 10.1080/0284186X.2019.1566775.

3. Cenik F, Mähr B, Palma S, et al. Role of physical medicine for cancer rehabilitation and return to work under the premise of the "Wiedereingliederungsteilzeitgesetz". Wien Klin Wochenschr. 2019 Oct; 131 (19-20): 455-61. DOI: 10.1007/s00508-019-1504-7.

4. Chimenti RL, Frey-Law LA, Sluka KA. A mechanism-based approach to physical therapist management of pain. Phys Ther. 2018; 98 (5): 302-14. DOI: 10.1093/ptj/pzy030.

5. De Groef A, Penen F, Dams L, et al. Best-evidence rehabilitation for chronic pain part 2: pain during and after cancer treatment. $J$ Clin Med. 2019 Jul 5; 8 (7):979. DOI: 10.3390/jcm8070979.

6. Dean E, Skinner M, Myezwa $H$, et al. Health competency standards in physical therapist practice. Phys Ther. 2019; 99 (9): 1242-54. DOI: 10.1093/ptj/pzz087.

7. Stout NL, Baima J, Swisher AK, et al. Systematic review of exercise systematic reviews in the cancer literature (2005-2017). PM R. 2017; 9 (9S2): 347-84. DOI: 10.1016/j.pmrj.2017.07.074.

8. Keilani M, Kainberger F, Pataraia A, et al. Typical aspects in the rehabilitation of cancer patients suffering from metastatic bone disease or multiple myeloma. Wien Klin Wochenschr. 2019; 131 (21-22): 567-75. DOI: 10.1007/s00508-019-1524-3.

9. Ciuca A, Baban A. Psychological factors and psychosocial interventions for cancer related pain. Rom J Intern Med. 2017; 55 (2): 63-68. DOI: 10.1515/rijm-2017-0010.

10. Nakano J, Hashizume K, Fukushima T, et al. Effects of aerobic and resistance exercises on physical symptoms in cancer patients: a meta-analysis. Integr. Cancer Ther. 2018; 17 (4): 1048-58. DOI: 10.1177/1534735418807555

11. Lahart IM, Metsios GS, Nevill AM, Carmichael AR. Physical activity for women with breast cancer after adjuvant therapy. Cochrane Database of Systematic Rev. 2018 Jan 29; 1 (1): CD011292. DOI: 10.1002/14651858.CD011292.pub2.

12. Rice D, Nijs J, Kosek E, et al. Exercise induced hypoalgesia in pain-free and chronic pain populations: State of the art and future directions. J Pain. 2019 Nov; 20 (11): 1249-66. pii: S15265900(18)30456-5. DOI: 10.1016/j.jpain.2019.03.005.

13. Nahm N, Mee S, Marx G. Efficacy of management strategies for aromatase inhibitor-induced arthralgia in breast cancer patients: A systematic review. Asian Pac J Clin Oncol. 2018; 14 (6): 374-82. DOI: 10.1111/ajco.12845.

14. Irwin ML, Cartmel B, Gross CP, et al. Randomized exercise trial of aromatase inhibitor-induced arthralgia in breast cancer survivors. J Clin Oncol. 2015; 33 (10): 1104-11. DOI: 10.1200/ JCO.2014.57.1547.

15. Pinto-Carral A, Molina AJ, de Pedro A, Ayan C. Pilates for women with breast cancer: A systematicreview and meta-analysis. Complementary Ther Med. 2018; 41: 130-40. DOI: 10.1016/j. ctim.2018.09.011.

16. Danhauer SC, Addington EL, Cohen L, et al. Yoga for symptom

management in oncology: A review of the evidence base and future directions for research. Cancer. 2019; 125 (12): 1979-89. DOI: 10.1002/cncr.31979.

17. McDermott LA, Murphy MH, McNeilly AM, et al. Biological markers as an outcome measure of exercise in cancer rehabilitation: A systematic review. J Cancer Res Ther. 2018; 14 (2): 267-77. DOI: 10.4103/0973-1482.191036.

18. Pergolotti M, Deal AM, Williams GR, et al. Older adults with cancer: a randomized controlled trial of occupational and physical therapy. J Am Geriatr Soc. 2019; 67 (5): 953-60. DOI: 10.1111/ jgs. 15930.

19. Cešeiko R, Eglïtis J, Srebnijs A, et al. The impact of maximal strength training on quality of life among women with breast cancer undergoing treatment. Exp Oncol. 2019; 41 (2): 166-72. DOI: 10.32471/exp-oncology.2312-8852.vol-41-no-2.13249.

20. Schulz SVW, Laszlo R, Otto S, et al. Feasibility and effects of a combined adjuvant high-intensity interval/strength training in breast cancer patients: a single-center pilot study. Disabil Rehabil. 2018; 40 (13): 1501-08. DOI: 10.1080/09638288.2017.1300688.

21. Mirandola D, Miccinesi G, Muraca MG, et al. Longitudinal assessment of the impact of adapted physical activity on upper limb disability and quality of life in breast cancer survivors from an Italian cohort. Support Care Cancer. 2018; 26 (2): 329-32. DOI: 10.1007/s00520-017-3930-2.

22. Paolucci $\mathrm{T}$, Bernetti $\mathrm{A}$, Paoloni $\mathrm{M}$, et al. Therapeutic alliance in a single versus group rehabilitative setting after breast cancer surgery: psychological profile and performance rehabilitation. Biores Open Access. 2019; 8 (1): 101-10. DOI: 10.1089/ biores.2019.0011.

23. Travier N, Buckland G, Vendrell JJ, et al. Changes in metabolic risk, insulin resistance, leptin and adiponectin following a lifestyle intervention in overweight and obese breast cancer survivors. Eur $\mathrm{J}$ Cancer Care. 2018; 27 (4): e12861. DOI: 10.1111/ecc.12861.

24. Kulik-Parobczy I. Evaluation of the effectiveness of physiotherapy in patients after oncological breast cancer treatment based on spirometric indicators. Contemp Oncol (Pozn). 2019; 23 (1): 4751. DOI: 10.5114/wo.2019.82929.

25. Janssen SMJ, Abbink JJ, Lindeboom R, Vliet Vlieland TPM. Outcomes of pulmonary rehabilitation after treatment for nonsmall cell lung cancer stages I to Illa: an observational study. J Cardiopulm Rehabil Prev. 2017; 37 (1): 65-71. DOI: 10.1097/ HCR.0000000000000227.

26. Edbrooke L, Aranda S, Granger CL, et al. Multidisciplinary homebased rehabilitation in inoperable lung cancer: a randomised controlled trial. Thorax. 2019; 74 (8): 787-96. DOI:10.1136/ thoraxjnl-2018-212996.

27. Peddle-Mclntyre CJ, Singh F, Thomas R, et al. Exercise training for advanced lung cancer. Cochrane Database Syst Rev. 2019; 2 (2): CD012685. DOI: 10.1002/14651858.CD012685.pub2.

28. Batchelor TJP, Rasburn NJ, Abdelnour-Berchtold E, et al. Guidelines for enhanced recovery after lung surgery: recommendations of the enhanced recovery after surgery (ERASVR ) society and the European Society of Thoracic Surgeons (ESTS). Eur J Cardiothorac Surg. 2019; 55 (1): 91-115. DOI: 10.1093/ejcts/ezy301.

29. Olivier C, Grosbois JM, Cortot AB, et al. Real-life feasibility of 
home-based pulmonary rehabilitation in chemotherapy-treated patients with thoracic cancers: a pilot study. BMC Cancer. 2018; 18 (1): 178. DOI: 10.1186/s12885-018-4102-6.

30. Liu X, Wang YQ, Xie J. Effects of breathing exercises on patients with lung cancer. Oncol Nurs Forum. 2019; 46 (3): 303-17. DOI: 10.1188/19.ONF.303-317.

31. Steiner MC. Should pulmonary rehabilitation be a standard of care in lung cancer? Thorax. 2019; 74 (8): 725-6. DOI: 10.1136/ thoraxjnl-2019-213157.

32. Da Silva JR Jr, Wiegert EVM, Oliveira L, Calixto-Lima L. Different methods for diagnosis of sarcopenia and its association with nutritional status and survival in patients with advanced cancer in palliative care. Nutrition. 2018; 60: 48-52. DOI: 10.1016/j. nut.2018.09.003

33. Fukushima T, Nakano J, Ishii S, et al. Factors associated with muscle function in patients with hematologic malignancies undergoing chemotherapy. Support Care Cancer. 2020 Mar; 28 (3): 1433-9. DOI: 10.1007/s00520-019-04955-2.

34. Damlaj M, El Fakih R, Hashmi SK. Evolution of survivorship in lymphoma, myeloma and leukemia: Metamorphosis of the feld into long term follow-up care. Blood Rev. 2019; 3: 63-73. DOl: 10.1016/j.blre.2018.07.003.

35. Hackett F, Dowling M. Lymphoma survivors' experiences at the end of treatment. J Clin Nurs. 2019; 28 (3-4): 400-9. DOl: 10.1111/jocn.14658

36. Raphael D, Frey R, Gott M. Maintaining psychosocial wellbeing for post-treatment haematological cancer survivors: Strategies and potential barriers. Eur J Oncol Nurs. 2019; 38: 36-41. DOl: 10.1016/j.ejon.2018.11.011

37. Hathiramani S, Pettengell R, Moir H, Younis A. Relaxation and exercise in lymphoma survivors (REIL study). BMC Sports Sc Med Rehabil. 2019; 11: 17. DOI: 10.1186/s13102-019-0127-7.

38. Frawley HC, Lin KY, Granger CL, et al. An allied health rehabilitation program for patients following surgery for abdomino-pelvic cancer: a feasibility and pilot clinical study. Support Care Cancer. 2020 Mar; 28 (3): 1335-50. DOI: 10.1007/s00520-019-04931-w.

39. Hegedus A, Trzaskoma L, Soldos P, et al. Adaptation of fatigue affected changes in muscle EMG frequency characteristics for the determination of training load in physical therapy for cancer patients. Pathol Oncol Res. 2020 Apr; 26 (2): 1129-35. DOl: 10.1007/s12253-019-00668-3.

40. Santa Mina D, Au D, Auger LE, et al. Development, implementation, and effects of a cancer center's exercise-oncology program. Cancer. 2019; 125 (19): 3437-47. DOl: 10.1002/cncr.32297.

41. Sharma R, Molinares-Mejia D, Khanna A, et al. Training and practice patterns in cancer rehabilitation: a survey of physiatrists specializing in oncology care. Phys Med Rehab. 2020 Feb; 12 (2): 180-5. DOI: 10.1002/pmrj.12196.

42. Hathiramani S, Pettengell R, Moir H, Younis A. Lymphoma survivors' experience of participation in a home-based intervention post-chemotherapy. Qual Life Res. 2019 Nov; 28 (11): 2951-5. DOI: 10.1007/s11136-019-02244-3.

43. Stubblefield MD, Kendig TD, Khanna A. ReVitalizing cancer survivors - making cancer rehabilitation the standard of care. MD Advis. Spring 2019; 12 (2): 30-33.

44. Stout NL, Silver JK, Alfano CM, et al. Long-term survivorship care after cancer treatment: a new emphasis on the role of rehabilitation services. Phys Ther. 2019; 99 (1): 10-13. DOI: 10.1093/ptj/pzy115.

45. Yadav RR, Ngo-Huang AT, Ng A, et al. Characteristics of cancer rehabilitation fellowship training programs in the USA. J Cancer Educ. 2018; 33 (6): 1364-7. DOI: 10.1007/s13187-018-1371-3.

46. Hutchison N, Deval N, Rabusch S, et al. Physical therapy based exercise protocol for cancer patients: Evaluating outcomes for cardiopulmonary performance and cancer-related fatigue. PM R. 2019 Feb 6. DOI: 10.1002/pmrj.12128. 


\title{
FEATURES OF INTERLABORATORY COMPARISON METHODS WHEN MEASURING VIBROACOUSTIC PARAMETERS
}

Sterlikov AV ${ }^{1}$, Kurilenko YuV², Voronkov $A A^{2}$

${ }^{1}$ Research and Technical Center of Radiation-Chemical Safety and Hygiene of Federal Medical-Biological Agency, Moscow, Russia

2 Tsifrovye Pribory Ltd, Moscow, Russia

External quality control in the form of interlaboratory comparisons (ILCs) is an important criterion of the testing laboratory competence. The study was aimed to summarize the approaches to developing objects for proficiency testing (OPT) based on physical simulation of acoustic noise sources, airborne ultrasound, vibration, and the practice of their use for ILC. Analysis of the OPT effectiveness based on physical simulation of factors, the test benches (TBs), was performed based on their testing and certification results, as well as on the results of appropriate ILCs. The results of using TB as OPT are considered for the following factors: acoustic noise, airborne ultrasound, and vibration. When measuring acoustic noise, TB played back the acoustic noise record with high stability. ILC involving measurement of airborne ultrasound was performed the same way, however, the frequency of the acoustic signal being reproduced was in the range of $11-22 \mathrm{kHz}$. TBs, based on a manual mechanized tool and a platform equipped with electromechanical agitator, were developed for ILC involving the measurement of local and general vibration. Stability of vibration generated was provided by means of the automated system for maintaining the set level with feedback and proportional integral derivative (PID) controller. When arranging and performing ILCs involving measurement of noise and vibration, a crucial role is played by the methods developed specifically for ILCs, allowing one to take into account all the conditions that affect the measurement results.

Keywords: interlaboratory comparison, acoustic noise, ultrasound, vibration measurement

Author contribution: all authors contributed to data acquisition, data compilation, and manuscript writing.

$\triangle$ Correspondence should be addressed: Alexander V. Sterlikov

Shchukinskaya, 40, Moscow, 123182; asterlikov@mail.ru

Received: 27.05.2021 Accepted: 11.06.2021 Published online: 18.06.2021

DOI: $10.47183 /$ mes.2021.012

\section{ОСОБЕННОСТИ МЕТОДОВ ПРОВЕДЕНИЯ МЕЖЛАБОРАТОРНЫХ СЛИЧЕНИЙ ПРИ ИЗМЕРЕНИИ ВИБРОАКУСТИЧЕСКИХ ПОКАЗАТЕЛЕЙ}

\author{
А. В. Стерликов ${ }^{1}$, Ю. В. Куриленко ${ }^{2}$ А. А. Воронков ${ }^{2}$ \\ ${ }^{1}$ Научно-технический центр радиационно-химической безопасности и гигиены, Москва, Россия \\ ${ }^{2}$ ООО «ПКФ Цифровые приборы», Москва, Россия
}

\begin{abstract}
Важным критерием компетентности испытательных лабораторий являются результаты внешнего контроля качества в форме межлабораторных сличительных испытаний (МСИ). Целью работы было обобщить подходы к созданию объектов для проверки квалификации (ОПК) на основе физических моделей источников акустического шума, воздушного ультразвука, вибрации и их использования для проведения Мси. Анализ эффективности ОПК на основе физических моделей факторов - испытательных стендов (ИС) производили по результатам их испытаний и аттестации, а также по результатам МСИ с их использованием. Рассмотрены результаты использования ИС в качестве ОПК факторами акустического шума, ультразвука и вибрации. При измерениях акустического шума ИС воспроизводил его запись с высокой стабильностью. Аналогичным образом осуществляли Мси с измерением уровня воздушного ультразвука, но частота воспроизводимого акустического сигнала находилась в диапазоне 11-22 кГц. Для проведения МСИ с измерением локальной и общей вибрации были разработаны ИС на основе ручного механизированного инструмента и платформы с электромеханическим побудителем. Стабильность уровня генерируемой вибрации обеспечивало применение системы автоматизированного поддержания заданного уровня с обратной связью и использованием пропорционально-интегрально-дифференциального регулятора. При организации и проведении МСИ с измерением шума и вибрации значительную роль играют методики, разработанные специально для проведения МСИ и позволяющие учесть все условия, влияющие на результаты измерений.
\end{abstract}

Ключевые слова: межлабораторные сличительные испытания, акустический шум, ультразвук, измерение вибрации

Вклад авторов: все авторы участвовали в сборе экспериментальных данных, их обобщении и подготовке статьи.

$\triangle$ Для корреспонденции: Александр Васильевич Стерликов ул. Щукинская, д. 40, г. Москва, 123182; asterlikov@mail.ru

Статья получена: 27.05.2021 Статья принята к печати: 11.06.2021 Опубликована онлайн: 18.06.2021

DOI: $10.47183 /$ mes.2021.012

The results of external quality control in the form of interlaboratory comparisons (ILCS) are an important criterion of the testing laboratory competence. The need for participation in ILCs is one of the requirements for testing laboratories codified in the law $[1,2]$. Control over compliance with these requirements is exercised by both Rosaccreditation, and executive authorities in charge of accredited organizations $[3,4]$.

Among tests, studies, and measurements performed in order to evaluate compliance to hygiene standards, there are many direct measurements of physical factors, such as acoustic noise and vibration. Over recent years there has been an upward trend in the number of those [5].
Conducting ILCs when measuring physical factors, affecting humans in their living environment, such as acoustic noise and vibration, has a number of features. The main feature is that the object, the properties of which are being measured in the laboratory, cannot be sent to participants for measurement. Working place and residential development area can be considered the examples of such objects. Thus, the model objects are used for proficiency testing (OPT). It therefore seems necessary to perform ILC at the premises of provider ensuring availability of OPT and stability of OPT parameters. The other feature of noise and vibration measurement is impossibility of simultaneous measurement of one object by 
several laboratories, i.e. impossibility of conducting ILCs with the use of parallel programs. That is why the ILC providers use sequential programs with sequential access to OPT being the source of the measured factor. Meanwhile, the measured OPT parameters stability is controlled by reference laboratory [6] authorized by ILC provider.

Such practice of ILCs has been carried out since 2016 within the framework of the PHYSFACTOR-TEST voluntary certification system, as well as by other ILC providers [7, 8]. The method for carrying out and arranging ILCs when performing direct measurements has been reported [9].

The presence of OPT with appropriate characteristics is a key requirement to performing ILC using the approach described above.

Both natural and model objects may be used as OPTs. The model objects' assessed parameters stability is ensured by specialized test benches (TBs).

When performing ILCs involving measurement of acoustic noise and vibration, it is difficult to use natural objects due to low stability, unpredictability of parameter changes during measurement, and impossibility of setting specific parameters.

The study was aimed to summarize the approaches to creation and the practice of using OPT based on physical simulation of acoustic noise sources, airborne ultrasound, and vibration for ILC, as well as to assess the effectiveness of using the TB developed as an OPT for ILC with measurement of acoustic noise and vibration.

\section{METHODS}

Analysis of the effectiveness of OPTs based on physical simulation of factors, the test benches (TB), was carried out based on the results of TB testing and standardization, as well as the results of ILCs performed with the use of those.

The basic requirements for TB are as follows:

- the level of the factor generated should be in the range from the value three times (or by $10 \mathrm{~dB}$ ) exceeding the detection threshold of the measurement systems, most commonly used by laboratories, to the level around the threshold limit value;

- parameters of the studied feature (hereinafter the factor) should remain stable for at least 20-60 min;

- susceptibility of TB performance to environmental factors should be kept to a minimum; there should also be a possibility of considering the impact of these factors;

- it is necessary to ensure carrying out ILCs by all participants by way of a sequential access to TB;

- it is necessary to take into account the measurement technique (direct measurement method) and the features of using the measurement system;

- TB should adequately simulate the impact of the measured factor on the environment (working place, working area);

- when constructing TB, it is necessary to strike a balance between thorough simulation of the factor impact on environmental objects and ensuring the stability and reproducibility of measurements;

- TB should enable setting various modes and factor intensities;

- TB should ensure reproducibility of levels being monitored when performing repeated measurements during the TB operation in the course of ILC;

- when using TB, it is necessary to ensure resistance to externally acting interfering influences (interference immunity).

The results of using TB as an OPT were treated based on the following factors:

- acoustic noise;
- airborne ultrasound;

- local vibration;

- general machinery and household appliances vibration.

ILCs and measurements in the course of TB testing were carried out in accordance with the previously developed programs using the methods that had successfully passed metrological standardization. The ILC participants knew in advance the documents and were provided additional training prior to ILC.

All measurements were performed using the following measurement devices:

- Ecophysika-110A system (OCTAVA-ElectronDesign; Russia);

- AK-1000 acoustic calibrator (OCTAVA-ElectronDesign; Russia);

- KB-160 portable vibration reproducing device (vibrocalibrator) (OCTAVA-ElectronDesign. Russia).

\section{RESULTS}

Acoustical noise was the first type of ILC of physical factors. Currently, distribution of acoustic signal record as a reference for proficiency testing is being widely practiced. However, first, under this approach it could not be said that OPT is the same object the laboratory investigates. According to their areas of accreditation, laboratories perform measurements on various environmental objects (working areas, human living environment) or equipment testing. Under the approach discussed above, OPT is a speaker or digital recording; second, such approach in its current form has outlived its purpose and does not enable us to judge the ILC participant proficiency due to impossibility to perform quantitative comparison of the measurement results with the reproduced value. Furthermore, the content of measurement tasks does not comply with the changed regulatory framework.

In order to ensure interlaboratory comparison, we constructed TBs, playing back the noise with high stability. TBs consisted of waveform generator, power amplifier, and highquality full-range speaker. In order to assess the short-term stability, we used the reproduced by TB noise parameters of the model OPT, averaged during direct measurement. During the short periods, corresponding to typical ILC duration (up to $120 \mathrm{~min}$ ), this parameter varied within the limit of $\pm 0.5 \mathrm{~dB}$, which provided the short-term TB stability appropriate for ILC. Within the interval of several months with the same settings, the noise level reproduced by TB varied within the limit of \pm $2 \mathrm{~dB}$, which provided the long-term stability appropriate for continuous operation of TB.

The area of the facility, in which the measurement is performed, should be at least $40 \mathrm{~m}^{2}$, and the minimum linear size of the facility should be at least $2.5 \mathrm{~m}^{2}$. Standard room environment conditions for temperature, humidity, pressure, and air velocity should be maintained.

Test points should be selected $1 \mathrm{~m}$ away from the sound source at a height of $1.5 \mathrm{~m}$ from the surface of the floor. The reference point should be no closer than $1 \mathrm{~m}$ from the walls, window and door openings. Depending on the number of measured noise parameters and measurement program, the number of reference points may vary between 1 and 4 .

Sensitivity of sound level meter (measurement system) was tested prior to measurement. The testing was performed in accordance with the sound level meter user guide. Sensitivity test was carried out using class 1 acoustic calibrator by GOST IEC 60942 having the verification certificate and approved by the sound level meter manufacturer.

During the measurements, the acoustic level (acoustic pressure) of background noise should be different from 
the acoustic level (acoustic pressure), provided by operating source, by not less than $10 \mathrm{~dB}$. There should be no random noise in the facility.

The test duration was at least $1 \mathrm{~min}$, and the number of measurements for each reference point was at least 3.

Measurement accuracy in accordance with the method used $[10,11]$ is characterized by expanded uncertainty of measurements with a coverage factor of 2, corresponding to 95\% confidence interval. Expanded uncertainty of measured acoustic level with the method applied does not exceed $1.2 \mathrm{~dB}$, and the expanded uncertainty of measured acoustic pressure does not exceed $2.2 \mathrm{~dB}$.

More than 150 interlaboratory comparisons have been carried out.

Performing ILC with the acoustic level (acoustic pressure) measurement using the discussed TB met the need for correct comparison of the results obtained by the ILC participants and the reference laboratory, as well as for adequate simulation of the real world conditions of acoustic noise measurement at the working place or other object. The proposed ILC method made it possible to set different levels for the factor to be measured. When conducting measurement, it is necessary to maintain the conditions required for prevention of erroneous results.

ILC with the airborne ultrasound level measurement was performed the same way. Design of TB, being the object for proficiency testing, was almost the same, however, the frequency of the acoustic signal played back was within the range of 11-22 kHz. High-frequency transducer with high pass filter having a cut-off frequency of $7-9 \mathrm{kHz}$ was used to play back ultrasound signals.

TB simulated the source of airborne ultrasound at the working place. The 1/3-octave-band acoustic pressure level was measured. TB made it possible to achieve the acoustic pressure levels of up to 85-87 dB.

The requirements for conducting measurements are generally the same as for acoustic noise parameters measurement. However, the important factor affecting the measurement results is pointing the sound level meter microphone at the source of ultrasound signal. In some microphones, it is necessary to consider the parameter adjustment for ultrasonic frequency range.

All acoustic measurements during ILC were performed with the microphone fixed in the reference point with a rack.

Interlaboratory comparisons, when vibration is measured by testing laboratories, are no less urgent and much more complex in terms of arranging and conducting. The measurement results are influenced by numerous factors: vibration source stability resulting from its design and operating mode, type

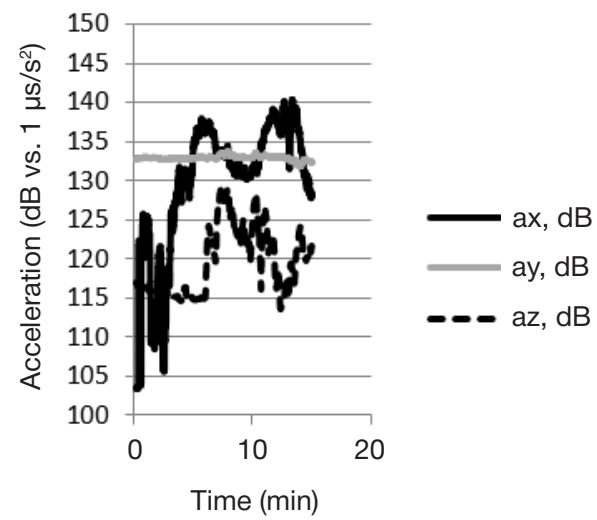

Vibration level with no feedback

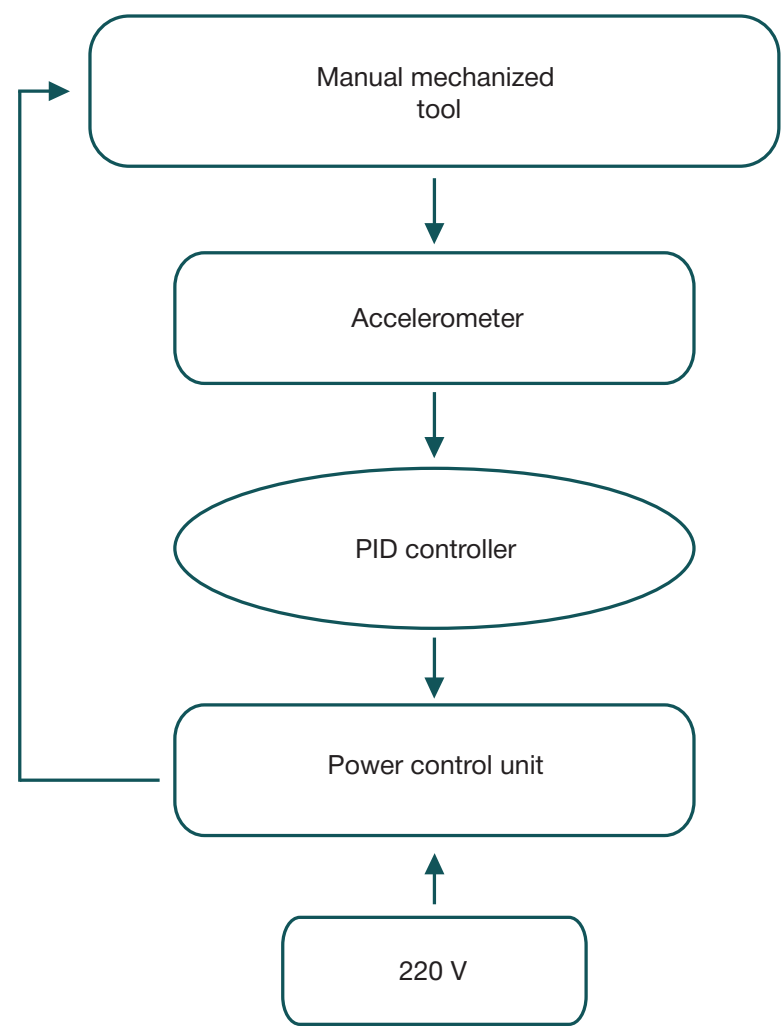

Fig. 1. Flow chart for the physical model of TB for local vibration OPT with automated maintenance of specified vibration acceleration level

and quality of the measurement system transducer fastening, mechanical interaction of the "worker-instrument-processed object" system, etc. That is why vibration measurement during simple simulation of the working process with the use of manual mechanized tool by the user would result in sharp discontinuities in the results, i.e. actually, there no short-term and long-term stability of measurements would be observed. This would make it difficult to compare these during interlaboratory comparisons. In addition, the user would be adversely affected by vibration. Even greater difficulties can be expected while ensuring measurement of general vibration, provided mostly by massive equipment and transport.

The circumstances described above have made it necessary to develop TBs that could be used as a part of OPT to measure the general vibration levels during ILCs.

Initially, the possibility of measuring local vibration with an instrument in idle or eccentric loading mode was studied.

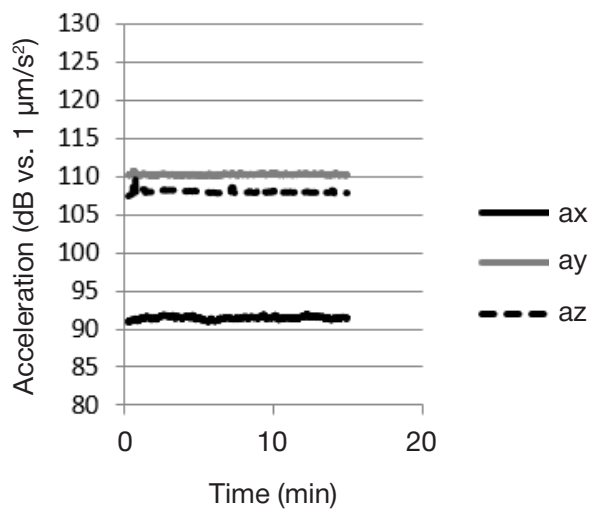

Vibration level with feedback

Fig. 2. Multifunction tool vibration levels with the specified vibration acceleration level maintenance system off and on 
However, in this case, stability proved insufficient. Thus, TB with automated specified mechanized tool vibration level maintenance using the proportional integral derivative (PID) controller was designed (Fig. 1). Multifunction tool or drilling machine supported by hanger (bracing) was used as a manual mechanized tool.

The results of comparative vibration level measurements in the presence and absence of feedback are presented in Fig. 2.

The data presented demonstrate that the system with feedback shows much more stable levels of local vibration generated for vibration acceleration. This justifies the increased complexity of TB for ILCs with measurement of local vibration.

To date, over 100 interlaboratory comparisons with the use of discussed TB have been performed.

When performing ILC with measurement of local vibration, a three-component vibration sensor was fixed on the instrument handle with a cubicle adapter in accordance with GOST 31192.2 [12]. Sensitivity axes of the vibration sensors were oriented in the $Z, X$ and $Y$ directions in accordance with the basicentric coordinate system of the human hand doing the work [13]. The absence of interference caused by electromagnetic fields and sensor cable movement were checked prior to measurement. Microclimatic conditions were consistent with the measurement system operation conditions.

The measurement was performed during a number of observation periods. At least four measurements of adjusted acceleration for each direction in each reference point were performed during each observation period. The duration of each test was at least $15 \mathrm{~s}$.

Measurement accuracy in accordance with the method used [14] is characterized by expanded uncertainty of measurements with a coverage factor of 2, corresponding to 95\% confidence interval. Expanded uncertainty of measurements performed using the method does not exceed $3.8 \mathrm{~dB}$.

TB made it possible to achieve the level of vibration acceleration up to $135 \mathrm{~dB}$.

The reported approach to performing ILC with the use of TB to generate stable vibration met the need for correct comparison of the results obtained by the ILC participants and the reference laboratory, as well as for adequate simulation of the real world conditions of local vibration measurement at the working place. The designed TB made it possible to set various levels of the factor to be measured, and ensured stable vibration generation.

A number of testing laboratories need to perform interlaboratory comparisons when measuring general machinery or household appliances vibration. Hygienic characteristics and standards of general machinery vibration, as well as the procedure of general machinery vibration measurement, differ from those of local vibration. General machinery vibration and household appliances vibration are the low-frequency vibration types, and are measured with the use of adapter, for example the floor standing platform mounted on the surface, on which the measurement is performed.

It is extremely difficult to perform ILCs with the measurement of general vibration on the basis of the physical object, therefore, it was necessary to develop the TB simulating the general vibration source. Such TB was developed. It was a platform sized $300 \times 300 \mathrm{~mm}$ with a $3000 \mathrm{rpm}$ electric motor fastened from below. The electric motor was operated in the eccentric loading mode, which resulted in vibration of the bench. In order to ensure stability and set the level of vibration acceleration, electric motor was included in the automatic control loop with vibration acceleration feedback, as described above. When performing measurement, the measurement system accelerometer was mounted on the platform surface. The platform itself was placed on a shock absorbing material.

TB made it possible to achieve vibration acceleration levels of up to $130 \mathrm{~dB}$. During TB standardization, it was found that the average level of general vibration generated (Z-axis $-L z)$ depending on the frequency $(F)$ was as follows:

\begin{tabular}{|c|c|}
\hline $\mathrm{F}, \mathrm{Hz}$ & $\mathrm{Lz}, \mathrm{dB}$ \\
\hline 4 & 60,1 \\
\hline 8 & 81,6 \\
\hline 16 & 103,1 \\
\hline 31,5 & 109,4 \\
\hline 64 & 94,5 \\
\hline
\end{tabular}

Thus, maximum energy of vibration acceleration was observed in octave bands of 16 and $31.5 \mathrm{~Hz}$, which was typical of general or household appliances vibration. For instance, such range corresponds to vibration induced by subway trains, and the $20-50 \mathrm{~Hz}$ frequency vibration is common to numerous industrial sources of general vibration.

Vibration acceleration was measured for 6 days, 4-6 measurements with test duration of $5 \mathrm{~min}$. It was found, that during the entire observation period the measured equivalent vibration acceleration levels fluctuated in the following way: for $X$-axis within the limit of $0.7 \mathrm{~dB}$; for $Y$-axis within the limit of $2.3 \mathrm{~dB}$, and for $Z$-axis within the limit of $1.0 \mathrm{~dB}$. During one measurement session, the measured vibration acceleration fluctuations did not exceed $0.2 \mathrm{~dB}$ for $X$-axis, 0.6 for $Y$-axis, and $0.5 \mathrm{~dB}$ for $Z$-axis, which indicated the short-term stability of measurements appropriate for ILC.

Thus, TB designed for ILCs with measurement of general vibration factor ensures adequate simulation of the real world conditions of the general vibration measurement and makes it possible to perform measurements with sequential ILC participants' access to TB. The use of discussed TB would enable correct comparison of the general vibration measurement results obtained by the ILC participants, and the reference laboratory. TB has been already introduced into the work of the ILC coordinator acting under the authority of the PHYSFACTOR-TEST voluntary certification system.

In case of small discontinuity of measured vibration acceleration values the expanded uncertainty can be calculated by classifying general vibration measurements as single measurements [15].

\section{DISCUSSION}

Currently, simulation of technological processes and situation at environmental objects is quite common for measurement of standardized physical factors. Therefore, the development and application of noise source physical models for the purposes of ILC are consistent with the established practice of such factors' measurement. The need for such simulation for the purposes of ILC results from the requirements for OPT.

TBs described in this report ensure adequate simulation of acoustic noise sources at the working place and other environmental objects, and make it possible to ensure interlaboratory comparisons for all the methods applied for acoustic noise and vibration parameter measurement.

TBs contained microcontroller vibration agitator controls with feedback, which provided appropriate stability of the generated local and general vibration.

The methods developed specifically for ILCs play a crucial role in arranging and conducting ILCs. The use of standardized 
measurement methods makes it possible to take into account all the conditions affecting the measurement results, and provide metrologically traceable measurements during ILC [10, 11, 14]. The measurement of acoustic pressure in the ultrasonic range and general vibration acceleration is performed as direct measurement in accordance with the ILC programs, however, the methods for measuring these factors are planned to be developed and standardized.

The ILC results are evaluated based in the $\mid$ En| criterion [6, 16], which ensures objectiveness of the judgment about the participating laboratory proficiency.

When performing ILC, it is possible to evaluate both the measurement results and the compliance with measurement procedure, which can be also used to assess the participants' proficiency.

\section{References}

1. Obshhie trebovanija $\mathrm{k}$ kompetentnosti ispytatel'nyh i kalibrovochnyh laboratorij GOST ISO/IEC 17025-2019. M.: Standartinform, 2019. Russian.

2. Ob utverzhdenii Kriteriev akkreditacii, perechnja dokumentov, podtverzhdajushhih sootvetstvie zajavitelja, akkreditovannogo lica kriterijam akkreditacii, i perechnja dokumentov $v$ oblast standartizacii, sobljudenie trebovanij kotoryh zajaviteljami, akkreditovannymi licami obespechivaet in sootvetstvie kriterijam akkreditacii. Prikaz Minjekonomrazvitija Rossii ot 30 maja 2014 g. Dostupno po ssylke: http://base.garant.ru/707/2358/ (data obrashhenija: 05.12.2016). Russian.

3. Ob utverzhdenii Polozhenija o sostave svedenij o rezul'tatah dejatel'nosti akkreditovannyh lic, ob izmenenijah sostava in rabotnikov i o kompetentnosti jetih rabotnikov, ob izmenenijah tehnicheskoj osnashhennosti, predstavljaemyh akkreditovannymi licami v Federal'nuju sluzhbu po akkreditacii, porjadke srokah predstavlenija akkreditovannymi licami takih svedenij $v$ Federal'nuju sluzhbu po akkreditacii. Prikaz Minjekonomrazvitija Rossii ot 30 maja 2014 g. \# 329. Dostupno po ssylke: http://docs. cntd.ru/document/420203445 (data obrashhenija: 12.06.2020). Russian.

4. Politika Rosakkreditacii $v$ otnoshenii proverki kvalifikacii putem provedenija mezhlaboratornyh slichitel'nyh (sravnitel'nyh) ispytanij, utverzhdena rukovoditelem Federal'noj sluzhby po akkreditacii 28.10.2016. Dostupno po ssylke: http://docs. cntd.ru/document/456085241 (data obrashhenija: 12.06.2020) Russian.

5. O sostojanii sanitarno-jepidemiologicheskogo blagopoluchija naselenija v Rossijskoj Federacii v 2018 godu. Gosudarstvenny] doklad [Jelektronnyj resurs]. Dostupno po ssylke: https://www. rospotrebnadzor.ru/upload/iblock/798/gosudarstvennyy-doklado-sostoyanii-sanitarno_epidemiologicheskogo-blagopoluchiyanaseleniya-v-rossiyskoy-federatsii-v-2018-godu.pdf (data obrashhenija: 12.06.2020). Russian.

6. Ocenka sootvetstvija. Osnovnye trebovanija $\mathrm{k}$ provedeniju proverki kvalifikacii GOST ISO/IEC 17043-2013. Dostupno po ssylke: https://files.stroyinf.ru/Data2/1/4293774/4293774569.pdf (data obrashhenija: 12.06.2020). Russian.

7. Centr mezhlaboratornyh sravnitel'nyh ispytanij SDS FIZFATORTEST https://www.octava.info/interlaboratory_comparison. Dostupno
According to the comments of the participants, participation in the ILCs in accordance with the discussed technology is of great importance in terms of self-esteem and personal proficiency improvement.

\section{CONCLUSION}

Rationale for technology of acoustic noise source physical simulation, used as an object for proficiency testing during the interlaboratory comparisons, has been provided. The test benches developed meet the desired characteristics of the objects for proficiency testing, and adequately simulate the conditions at the working places and other environmental objects. When verifying the laboratory proficiency, it is necessary to assess both measurement results and measurement procedure. po ssylke: https://files.stroyinf.ru/Data2/1/4293774/4293774569. pdf (data obrashhenija: 12.06.2020). Russian.

8. Plan provedenija mezhlaboratornyh slichitel'nyh ispytanij provajdera UNIIM - filial FGUP «VNIIM im. D.I. Mendeleeva» na 2020 god. Dostupno po ssylke: https://uniim.ru/planmsi2020/ (data obrashhenija: 12.06.2020). Russian.

9. Semjonov SYu, Sterlikov AV, Tananykin NI, Kolbutova KB, Kurilenko YuV, Voronkov AA. Vneshnij kontrol' kachestva issledovanij $v$ ispytatel'nyh laboratorijah pri provedenii prjamyh izmerenij. Medicina jekstremal'nyh situacij. 2018; 20 (2): 223-30. Russian.

10. Metodika izmerenij urovnej zvuka i zvukovogo davlenija izluchenija istochnikov zvuka MI NPF-15-032 (FR. 1.36.2016.23826). OOO «NPF JelektronDizajn». M., 2015; 15 s. Russian.

11. Metodika izmerenij urovnej zvuka i zvukovogo davlenija izluchenija istochnikov zvuka MI NPF-17-032 (FR. 1.36.2017.26200). OOO NPF «JelektronDizajn». M., 2017; 15 s. Russian.

12. Vibracija. Izmerenie lokal'noj vibracii i ocenka ee vozdejstvija na cheloveka. Chast' 2. Trebovanija k provedeniju izmerenij na rabochih mestah, GOST 31192.2-2005. Dostupno po ssylke: http://docs.cntd.ru/document/1200060914 (data obrashhenija: 12.06.2020). Russian.

13. Gigienicheskie normativy i trebovanija k obespecheniju bezopasnosti i (ili) bezvrednosti dlja cheloveka faktorov sredy obitanija. SanPiN 1.2.3685-21. Dostupno po ssylke: https://docs. cntd.ru/search?q=\%D0\%A1\%D0\%B0\%D0\%BD\%D0\%9F\%D0 \%B8\%D0\%9D\%201.2.3685-2 (data obrashhenija: 10.06.2021). Russian.

14. Metodika izmerenij vibracii ruchnoj mashiny, MI NPF-16-033. 000 «NPF JelektronDizajn». M., 2016; 18 s. Russian.

15. Izmerenija prjamye odnokratnye. Ocenivanie pogreshnostej neopredelennosti rezul'tata izmerenij R 50.2.038-2004 Gruppa T80. Rekomendacii po metrologii. Dostupno po ssylke: http:// docs.cntd.ru/document/1200037562 (data obrashhenija: 12.06.2020). Russian.

16. Statisticheskie metody. Primenenie pri jeksperimental'noj proverke kompetentnosti posredstvom mezhlaboratornyh sravnitel'nyh ispytanii, GOST R 50779.60-2017 (ISO 13528:2015). Dostupno po ssylke: https://docs.cntd.ru/document/1200146875 (data obrashhenija: 10.06.2021). Russian.

\section{Литература}

1. Общие требования к компетентности испытательных и калибровочных лабораторий ГОСТ ISO/IEC 17025-2019. М.: Стандартинформ, 2019.

2. Об утверждении Критериев аккредитации, перечня документов, подтверждающих соответствие заявителя, аккредитованного лица критериям аккредитации, и перечня

документов в области стандартизации, соблюдение требований которых заявителями, аккредитованными лицами обеспечивает их соответствие критериям аккредитации. Приказ Минэкономразвития России от 30 мая 2014 г. Доступно по ссылке: http://base.garant.ru/70712358/ (дата обращения: 05.12.2016). 
3. Об утверждении Положения о составе сведений о результатах деятельности аккредитованных лиц, об изменениях состава их работников и о компетентности этих работников, об изменениях технической оснащенности, представляемых аккредитованными лицами в Федеральную службу по аккредитации, порядке и сроках представления аккредитованными лицами таких сведений в Федеральную службу по аккредитации. Приказ Минэкономразвития России от 30 мая 2014 г. № 329. Доступно по ссылке: http://docs. cntd.ru/document/420203445 (дата обращения: 12.06.2020).

4. Политика Росаккредитации в отношении проверки квалификации путем проведения межлабораторных сличительных (сравнительных) испытаний, утверждена руководителем Федеральной службы по аккредитации 28.10.2016. Доступно по ссылке: http://docs.cntd.ru/ document/456085241 (дата обращения: 12.06.2020).

5. О состоянии санитарно-эпидемиологического благополучия населения в Российской Федерации в 2018 году. Государственный доклад [Электронный ресурс]. Доступно по ссылке: https://www.rospotrebnadzor.ru/upload/ iblock/798/gosudarstvennyy-doklad-o-sostoyanii-sanitarno epidemiologicheskogo-blagopoluchiya-naseleniya-v-rossiyskoyfederatsii-v-2018-godu.pdf (дата обращения: 12.06.2020).

6. Оценка соответствия. Основные требования к проведению проверки квалисиикации ГOCT ISO/IEC 17043-2013. Доступно по ссылке: https://files.stroyinf.ru/Data2/1/4293774/4293774569. pdf (дата обращения: 12.06.2020).

7. Центр межлабораторных сравнительных испытаний СДС ФИЗФАТОР-ТЕСТ https://www.octava.info/interlaboratory comparison. Доступно по ссылке: https://files.stroyinf.ru/ Data2/1/4293774/4293774569.pdf (дата обращения: 12.06.2020).

8. План проведения межлабораторных сличительных испытаний провайдера УНИИМ - филиал ФГУП «ВНИИМ им. Д.И. Менделеева" на 2020 год. Доступно по ссылке: https://uniim. ru/planmsi2020/ (дата обращения: 12.06.2020).
9. Семёнов С. Ю., Стерликов А. В., Тананыкин Н. И., Колбутова К. Б., Куриленко Ю. В., Воронков А. А. Внешний контроль качества исследований в испытательных лабораториях при проведении прямых измерений. Медицина экстремальных ситуаций. 2018; 20 (2): 223-30.

10. Методика измерений уровней звука и звукового давления излучения источников звука МИ НПФ-15-032 (ФР. 1.36.2016.23826). ООО «НПФ ЭлектронДизайн». М., 2015; 15 с.

11. Методика измерений уровней звука и звукового давления излучения источников звука МИ НПФ-17-032 (ФР 1.36.2017.26200). ООО НПФ «ЭлектронДизайн». М., 2017; $15 \mathrm{c}$.

12. Вибрация. Измерение локальной вибрации и оценка ее воздействия на человека. Часть 2. Требования к проведению измерений на рабочих местах, ГОСТ 31192.2-2005. Доступно по ссылке: http://docs.cntd.ru/document/1200060914 (дата обращения: 12.06.2020).

13. Гигиенические нормативы и требования к обеспечению безопасности и (или) безвредности для человека факторов среды обитания. СанПиН 1.2.3685-21. Доступно по ссылке: https://docs.cntd.ru/search?q=\%D0\%A1\%D0\%B0\%D0\%BD\% D0\%9F\%D0\%B8\%D0\%9D\%201.2.3685-2 (дата обращения: 10.06.2021).

14. Методика измерений вибрации ручной машины, МИ НПФ-16033. ООО «НПФ ЭлектронДизайн». М., 2016; 18 с.

15. Измерения прямые однократные. Оценивание погрешностей и неопределенности результата измерений Р 50.2.0382004 Группа Т80. Рекомендации по метрологии. Доступно по ссылке: http://docs.cntd.ru/document/1200037562 (дата обращения: 12.06.2020).

16. Статистические методы. Применение при экспериментальной проверке компетентности посредством межлабораторных сравнительных испытаний, ГОСТ Р 50779.60-2017 (ИСО 13528:2015). Доступно по ссылке: https://docs.cntd.ru/ document/1200146875 (дата обращения: 10.06.2021). 


\title{
THE LIMITATIONS AND CAPABILITIES OF WIPE SAMPLES ANALYSIS IN CONTROL OF CONTAMINATION OF FACILITIES WITH HIGHLY TOXIC ORGANIC COMPOUNDS
}

Shachneva MD凶, Leninskii MA, Savelieva El

Research Institute of Hygiene, Occupational Pathology and Human Ecology Leningrad Region, Russia

\begin{abstract}
Wipe sampling is widely used for microbiological control purposes. Sanitary and chemical studies also include analysis of samples wiped from the work surfaces during routine and periodic working conditions safety inspections at chemical facilities. The analysis also allows assessing the toxicity and hazard of items/structures that could be in contact with highly toxic substances. This study aimed to investigate the capabilities and limitations of the surface wipe sample analysis method in control of residual contamination of equipment and building structures of a former chemical weapons destruction facilities (CWDF) with sulfur mustard and O-isobutyl-S(2-diethylaminoethyl) methylphosphonothioate (VR), as well as their degradation products. Gas chromatography with tandem mass spectrometry (GC-MS/MS) enabled identification of the sulfur mustard markers, high-performance liquid chromatography with tandem mass spectrometry (HPLC-MS/MS) allowed identifying VR markers. An assessment of the matrix influence on the results of GC-MS/MS and HPLC-MS/MS analysis was carried out. The matrix effect was established to affect the results the most in case of HPLC-MS/MS analysis: for GC-MS/MS analysis of target substances, the matrix factor averaged at 60-80\%, for HPLC-MS/MS it was less than $40 \%$. The average percent sulfur mustard recoveries from three types of surfaces (PVC tiles, laminate and metal plates) was $9 \pm 2 \%, 0.13 \pm 0.02 \%$ and $0.10 \pm 0.03 \%$; in case of VR, the recoveries was $2.7 \pm 0.5 \%, 11.8 \pm 0.3 \%$ and $0.8 \pm 0.1 \%$, respectively. The limits of detection for sulfur mustard by GC-MS/MS and VR by HPLC-MS/MS were established at $0.001 \mathrm{MPL}$ and $0.02 \mathrm{MPL}$, respectively. The developed approaches were applied to the analysis of wipe samples from the surfaces of the equipment and engineering structures of the former CWDF.
\end{abstract}

Keywords: bis(2-chloroethyl)sulfide, O-isobutyl-S-(2-diethylaminoethyl) methylphosphonothioate, wipe samples, construction materials, gas chromatography, high-performance liquid chromatography, tandem mass spectrometry

Author contribution: Shachneva MD — carrying out the experiment, summarizing the results, article authoring and editing; Leninskii MA — carrying out the experiment, article authoring; Savelieva El — academic advising, article authoring.

$\square$ Correspondence should be addressed: Mariya D. Shachneva

Kapitolovo, r.p. Kuzmolovsky, Vsevolozhsky r., 188663 Leningradskaya obl.; shachneva_mariya@mail.ru

Received: 28.05.2021 Accepted: 14.06.2021 Published online: 26.06.2021

DOI: $10.47183 /$ mes.2021.018

\section{ВОЗМОЖНОСТИ И ОГРАНИЧЕНИЯ АНАЛИЗА СМЫВОВ С ПОВЕРХНОСТЕЙ ДЛЯ КОНТРОЛЯ КОНТАМИНАЦИИ ОБЪЕКТОВ ВЫСОКОТОКСИЧНЫМИ ОРГАНИЧЕСКИМИ СОЕДИНЕНИЯМИ}

\author{
М. Д. Шачнева $\square$, М. А. Ленинский, Е. И. Савельева
}

Научно-исследовательский институт гигиены, профпатологии и экологии человека Федерального медико-биологического агентства, Ленинградская область, Россия

\begin{abstract}
Отбор проб смывов с поверхностей широко применяют в целях микробиологического контроля. В санитарно-химических исследованиях также предусмотрен анализ смывов с рабочих поверхностей при проведении плановых и периодических проверок безопасности условий труда работников химических предприятий, а также для оценки токсичности и опасности объектов, которые могли находиться в контакте с высокотоксичными веществами. Целью работы было исследовать возможности и ограничения метода анализа смывов с поверхностей для контроля остаточного загрязнения оборудования и строительных конструкций бывшего предприятия по уничтожению химического оружия (УХО) сернистым ипритом и О-изобутил-S(2-диэтиламиноэтил)-метилфоссонотиоатом (VR), а также продуктами их трансформации. Маркеры иприта определяли методом газовой хроматографии с тандемным масс-спектрометрическим детектированием (ГХ-MC/MC), маркеры VR - методом жидкостной хроматограсрии с тандемным массспектрометрическим детектированием (ВЭЖХ-МС/MC). Проведена оценка матричного влияния на результаты ГХ-МС/МС и ВЭЖХ-МС/МС анализа. Показано, что матричное влияние наиболее существенно при анализе методом ВЭЖХ-МС/МС: матричный фактор при определении аналитов методом ГХ-МС/МС составил в среднем 60-80\%, методом ВЭЖХ-МС/МС - менее 40\%. Степень извлечения аналитов с трех типов поверхностей (плитки из

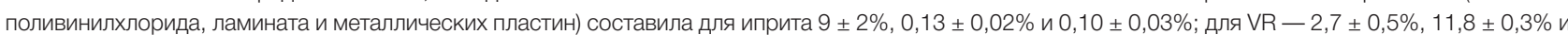

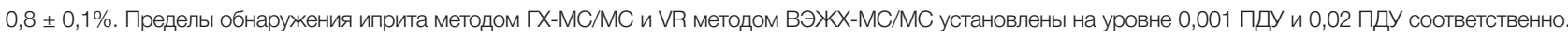
Разработанные подходы применены при анализе смывов с поверхностей оборудования и инженерных конструкций бывшего предприятия УХО.
\end{abstract}

Ключевые слова: бис(2-хлорэтил)сульсид, О-изобутил-S-(2-диэтиламиноэтил)-метилфоссонотиоат, смывы с поверхности, строительные материалы, газовая хроматография, высокоэффективная жидкостная хроматография, тандемное масс-спектрометрическое детектирование

Вклад авторов: М. Д. Шачнева - проведение эксперимента, обобщение результатов, написание и редактирование статьи; М. А. Ленинский проведение эксперимента, написание статьи; Е. И. Савельева - научное руководство, написание статьи.

$\bowtie$ Для корреспонденции: Мария Дмитриевна Шачнева Ст. Капитолово, г. п. Кузьмоловский, Всеволожский район, 188663, Ленинградская область; shachneva_mariya@mail.ru

Статья получена: 28.05.2021 Статья принята к печати: 14.06.2021 Опубликована онлайн: 26.06.2021

DOI: $10.47183 /$ mes.2021.018

The detection of toxic substances and their degradation products on the surfaces and in the deep layers of building materials is relevant for assessment of safety of infrastructure elements of former chemical weapons destruction facilities (CWDF) planned for conversion, as well as for investigations of incidents in the context of terrorist attacks or events of unintentional contact with buried chemical weapons.

There are regulations that govern activities of the federal state sanitary and epidemiological authorities supervising decommissioning and relief of consequences of operation of the chemical weapons storage and destruction facilities. A final conclusion on the safety of infrastructure of the facilities to be converted and used for civilian purposes requires comprehensive studies that include analysis of wipe samples from various surfaces within the facility. In a specific case of one of the CWDFs, sanitary and chemical studies enabling assessment of the process equipment and engineering infrastructure's safety were aimed at identifying the elements, 
units etc that had no traces of contamination with sulfur mustard and organophosphorus toxic substances. Bis (2-chloroethyl) sulfide (sulfur mustard) and O-isobutyl-S-(2-diethylaminoethyl) methylphosphonothioate (VR) were chosen as persistent markers of contamination.

Sulfur mustard is a blistering agent, a persistent organochlorine compound; it is easily sorbed on absorbent porous surfaces and can retain its ecotoxic properties for decades. The action of sulfur mustard is distinctly local: it affects the eyes and the respiratory organs, the gastrointestinal tract and the skin. Absorbed into the blood, it also acts as a systemic poison. 1,4-dithiane, one of the stable products of sulfur mustard degradation under chemical detoxification, was chosen as an analyte for control of contamination of the surfaces with the reaction masses from sulfur mustard destruction [1]. The detection of sulfur mustard in combination with 1,4-dithiane, a stable product of its degradation, increases the reliability of retrospective analysis.

As cholinesterase inhibitors, nerve agents (NA), including VR, act when inhaled, ingested or applied to skin. In the body, NA triggers excessive accumulation of acetylcholine and overexcitation of cholinergic receptors. The typical signs and symptoms of their effect are miosis, nausea, chest tightness, increased salivation and sweating, and lacrimation [2].

Compared to G-agents (sarin, soman) under similar conditions, V-agents, VR in particular, are less volatile and more persistent [3]. Consequently, a retrospective analysis of samples taken from the infrastructure of former CWDFs may reveal both the products of their detoxification and the VR itself. The most toxic product of VR hydrolysis is S-2-(diethylaminoethyl) methylphosphonothioate (DEAEMPT). By analogy with S-2(diisopropylaminoethyl)-methylphosphonothioate, which is the most toxic product of hydrolysis of $\mathrm{VX}$, DEAEMPT is only 3-10 times less toxic than VR [2], yet there were no hygienic standards developed for this extremely dangerous substance.

Wipe sampling is one of the most common sampling patterns in the context of examination of surfaces for contamination with toxic substances (pesticides, toxic metals, toxic substances, etc). However, the toxicants can penetrate deep into porous materials and become hard to extract, which is why wipe sampling is considered a method suitable only for non-porous materials. The gauze swabs used for wipe sampling should also be considered as a matrix capable of absorbing the analyte. Surface wiping brings target substances into the swab, from they are recovered with the help of the extracting solvent. A significant amount of analytes may be lost at both of these stages. The efficiency of extraction of analytes from the swabs can be established in model experiments and factored into the quantitative assessment of surface contamination of the controlled items. The possibility of recovery of analytes from the surfaces of specific materials and the efficiency of such recovery should be established through preliminary experiments with application of the target substances to the materials with the same surface texture as those of the controlled item.

This study aimed to investigate the capabilities and limitations of wipe sampling as applied to process equipment in the context of assessment of safety of infrastructure of the former CWDFs planned for conversion and subsequent use for civilian purposes.

\section{METHODS}

\section{Reagents and materials}

Sulfur mustard (GSO 8248-2003; Russia); O-isobutylS-(2-diethylaminoethyl) methylthiophosphonate, or VR
(GSO 8249-2004; Russia); 1,4-dithiane (Sigma-Aldrich; USA); S-[(2-diethylamino)ethyl] methylphosphonothioate, or DEAEMPT (enterprise standard 4/2019, Russia); methylene chloride (Supelco; USA); acetonitrile (Panreac; Spain); HPLC methanol (J.T. Baker; USA); formic acid (Sigma-Aldrich; USA).

\section{Study items}

Three types of materials were selected to investigate the efficiency of wipe sampling: PVC tiles, laminate and metal plates. The swabs were made of $10 \times 10 \mathrm{~cm}$ sections of medical gauze, treated with acetonitrile in a Soxhlet for 6-8 h, dried and folded in 16 layers.

\section{Model samples}

A solution of sulfur mustard and 1,4-dithiane in methylene chloride was applied to a $1 \mathrm{dm}^{2}$ area of the studied surfaces free from the target compounds, with the target concentration of each substance being $100 \mathrm{ng} / \mathrm{dm}^{2}$. The VR and DEAEMPT application conditions were the same, but their target concentrations were $50 \mathrm{ng} / \mathrm{dm}^{2}$. The samples were kept in a fume hood for 30 minutes.

\section{Wipe sampling}

A part of the controlled surface was sequentially wiped with two swabs moistened with methylene chloride (for sulfur mustard and 1,4-dithiane detection) or acetonitrile (for VR and DEAEMPT detection), and one dry swab. All three swabs were placed in a $7 \mathrm{ml}$ vial, capped and stored at $-20^{\circ} \mathrm{C}$ until analysis.

\section{Sample preparation for sulfur mustard and 1,4-dithiane determination}

Four $\mathrm{ml}$ of methylene chloride were added to the test sample (3 gauze swabs wiped against the surface). Target analytes were ultrasonically extracted for 5 minutes. The extract was transferred to a $7 \mathrm{ml}$ vial and the extraction procedure was repeated. The extracts were then combined and concentrated under a stream of nitrogen to a final volume of $0.2 \mathrm{ml}$ at room temperature. Two $\mu$ of the extract aliquot were analyzed by gas chromatography with tandem mass spectrometry in the electron ionization mode (GC-MS/MS-EI).

\section{Sample preparation for VR and DEAEMPT determination}

Four $\mathrm{ml}$ of methanol were added to a vial with swabs wiped against the surface. Target analytes were ultrasonically extracted for 5 minutes. The extract was transferred to a $7 \mathrm{ml}$ vial and the extraction procedure was repeated. The extracts were combined, concentrated under a stream of nitrogen to a final volume of $0.1 \mathrm{ml}$, then $0.2 \mu \mathrm{l}$ of $0.1 \%$ aqueous formic acid solution were added thereto and the resulting solution analyzed by high performance liquid chromatography with tandem mass spectrometry (HPLC-MS/MS).

\section{Equipment and conditions for instrumental analysis}

For sulfur mustard and 1,4-dithiane detection, we used a $7890 \mathrm{~A}$ gas chromatograph with a 7000 mass-selective detector with triple quadrupole (Agilent Technologies; USA) equipped with an HP-5MS capillary quartz column: $30 \mathrm{~m} \times 0.25 \mathrm{~mm} \times 0.25 \mu \mathrm{m}$ (Agilent Technologies; USA). Analysis conditions: injector temperature $-270{ }^{\circ} \mathrm{C}$; sample injection without flow splitting - 
Table 1. Detection parameters, sulfur mustard and 1,4-dithiane detected by GC-MS/MS-EI, VR and DEAEMPT by HPLC-MS/MS

\begin{tabular}{|c|c|c|}
\hline Compound detected & MRM transition (collision energy) & Retention time, min \\
\hline Sulfur mustard & $\begin{array}{c}109 \rightarrow 63(6 \mathrm{eV}) \\
158 \rightarrow 109(3 \mathrm{eV})\end{array}$ & 9 \\
\hline 1,4 -dithiane & $\begin{array}{c}120 \rightarrow 61(6 \mathrm{eV}) \\
120 \rightarrow 105(3 \mathrm{eV})\end{array}$ & 7.4 \\
\hline VR & $268,00 \rightarrow 100,10(-25 \mathrm{~V})$ \\
$268,00 \rightarrow 72,05(-34 \mathrm{~V})$ & 3.65 \\
\hline DEAEMPT & $212,10 \rightarrow 100,10(-20 \mathrm{~V})$ & 1.22 \\
\hline
\end{tabular}

1.0 minute; temperature program: $40^{\circ} \mathrm{C}(0 \mathrm{~min})-10^{\circ} \mathrm{C} / \mathrm{min}-$ $230^{\circ} \mathrm{C}(5$ minutes $)-15^{\circ} \mathrm{C} / \mathrm{min}-280^{\circ} \mathrm{C}(5$ minutes $)$; carrier gas - helium; carrier gas flow rate $-1 \mathrm{ml} / \mathrm{min}$; ion source temperature $-230^{\circ} \mathrm{C}$; interface temperature $-280^{\circ} \mathrm{C}$; energy of ionizing electrons - $70 \mathrm{eV}$; detection mode - multiple reaction monitoring (MRM) in the electron ionization (El) mode.

For VR and DEAEMPT detection, we used an LC-20AD liquid chromatograph equipped with an autosampler and an LCMS-8050 mass-selective detector with electrospray ionization at atmospheric pressure (Shimadzu; Japan). Gemini-NX 3u C18 110A chromatographic column (Phenomenex; USA): $150 \mathrm{~mm}$ $\times 0.2 \mathrm{~mm} \times 3.0 \mu \mathrm{m}$. Mass spectrometry parameters: drying gas flow rate $-10 \mathrm{ml} / \mathrm{min}$; auxiliary gas flow rate $-10 \mathrm{ml} / \mathrm{min}$; flow rate at the electrospray - $3 \mathrm{ml} / \mathrm{min}$; interface temperature $200{ }^{\circ} \mathrm{C}$; desolvation line temperature $-250{ }^{\circ} \mathrm{C}$; heater temperature $-350^{\circ} \mathrm{C}$; capillary voltage $-3500 \mathrm{~V}$; detection mode - MRM with registration of positively charged ions.

Table 1 shows the parameters for detection of sulfur mustard and 1,4-dithiane by GC-MS/MS-EI, VR and DEAEMPT by HPLC-MS/MS. Microsoft Excel (Microsoft; USA) enabled statistical processing of the data.

\section{RESULTS}

The methods developed to control contamination of work surfaces with sulfur mustard and VR rely on wipe sampling with cotton-gauze swabs. One of the studies [4] explores various swab material options (cotton wool, fabric, filter paper, fiberglass, etc). Fabric swabs delivered the best results. We compared the effectiveness of cotton-gauze and gauze swabs in extraction of a wide range of contaminants experimentally and found that swabs made of folded (several layers) gauze recovered more analytes from any surface, regardless of their nature. Therefore, we used swabs of $10 \times 10 \mathrm{~cm}$ pieces of medical gauze folded in several layers, washed with solvents and dried.

In case of wipe samples taken from the process equipment, the maximum permissible level (MPL) of sulfur mustard is $2 \times 10^{-4} \mathrm{mg} / \mathrm{dm}^{2}$, that of for VR $-2 \times 10^{-6} \mathrm{mg} / \mathrm{dm}^{2}$ [5]. The established hygienic standards set the requirements for sensitivity of analysis methods. For wipe samples from surfaces, the limit of detection (LOD) for sulfur mustard was set at $2 \times 10^{-7} \mathrm{mg} / \mathrm{dm}^{2}$ (0.001 MPL), that for 1,4-dithiane $-5 \times 10^{-8} \mathrm{mg} / \mathrm{dm}^{2}$. The LODs for DEAEMPT and VR were $6.5 \times 10^{-8}$ and $4.1 \times 10^{-8} \mathrm{mg} / \mathrm{dm}^{2}$ (0.02 MPL), respectively [6]. The tandem mass spectrometry detectors used ensured reliable identification of the analytes even at the lower detection limit.

\section{Assessment of the matrix effect}

The matrix factor was calculated with the help of the postextraction addition method: extracts from swabs (single, double, triple extraction) that did not contain analytes were analyzed after sulfur mustard and 1,4-dithiane or VR and DEAEMPT were added to them. The results obtained were compared with the results of analysis of the target compounds in a pure solvent, using formula 1. To assess the matrix factor for two- and three-fold extraction, the analytes were added to the combined extract:

$$
\mathrm{MF}=\frac{s_{p r}}{s_{r}} \times 100 \%,
$$

where MF is the matrix factor; Spr is the peak area of the analyte in the extract from swabs containing no sulfur mustard, 1,4-dithiane, VR, or DEAEMPT, after adding the target compounds to them; $\mathrm{Sr}$ is the peak area of the analyte in a pure solvent.

Table 2 shows the results of matrix factor (MF) calculation.

\section{Extraction efficiency of the analytes from gauze swabs}

In order to determine the extraction efficiency of sulfur mustard, 1,4-dithiane, VR, and DEAEMPT from gauze swabs, we placed three swabs in $7 \mathrm{ml}$ vials and added each analyte in concentration of $50 \mathrm{ng} / \mathrm{ml}$. After that, we carried out single, double, triple extraction of the target compounds with an appropriate solvent: methylene chloride for sulfur mustard and 1,4-dithiane, methanol for VR and DEAEMPT (see Figure).

The extraction efficiency was estimated using formula 2 :

$$
\mathrm{EE}=\frac{s_{p r}}{s_{r}} \times 100 \%,
$$

where EE is the extraction efficiency, \%; $S_{p r}$ is the analyte peak area in the extract from swabs with the target compounds added; $S_{r}$ is the analyte peak area in a pure solvent.

\section{Determination of the percent recovery of sulfur mustard and 1,4-dithiane, VR and DEAEMPT from various surfaces}

Table 3 shows the results of determining the percent recovery of sulfur mustard and 1,4-dithiane, VR and DEAEMPT from three types of surfaces the substances were applied to.

Table 2. Matrix factor (\%) in detection of sulfur mustard and 1,4-dithiane by GC-MS/MS, VR and DEAEMPT by HPLC-MS/MS, after adding the analytes to the extracts from blank swabs

\begin{tabular}{|c|c|c|c|}
\hline Parameter & Sulfur mustard & 1,4-dithiane & DEAEMPT \\
\hline MF, single extraction, $\%( \pm$ SD) & $67 \pm 4$ & $64 \pm 6$ & $21 \pm 6$ \\
\hline MF, double extraction, $\%( \pm$ SD) & $61 \pm 3 \pm 4$ & $71 \pm 5$ & $39 \pm 4$ \\
\hline MF, triple extraction, $\%( \pm$ SD) & $58 \pm 6$ & $76 \pm 8$ & $24 \pm 11$ \\
\hline
\end{tabular}




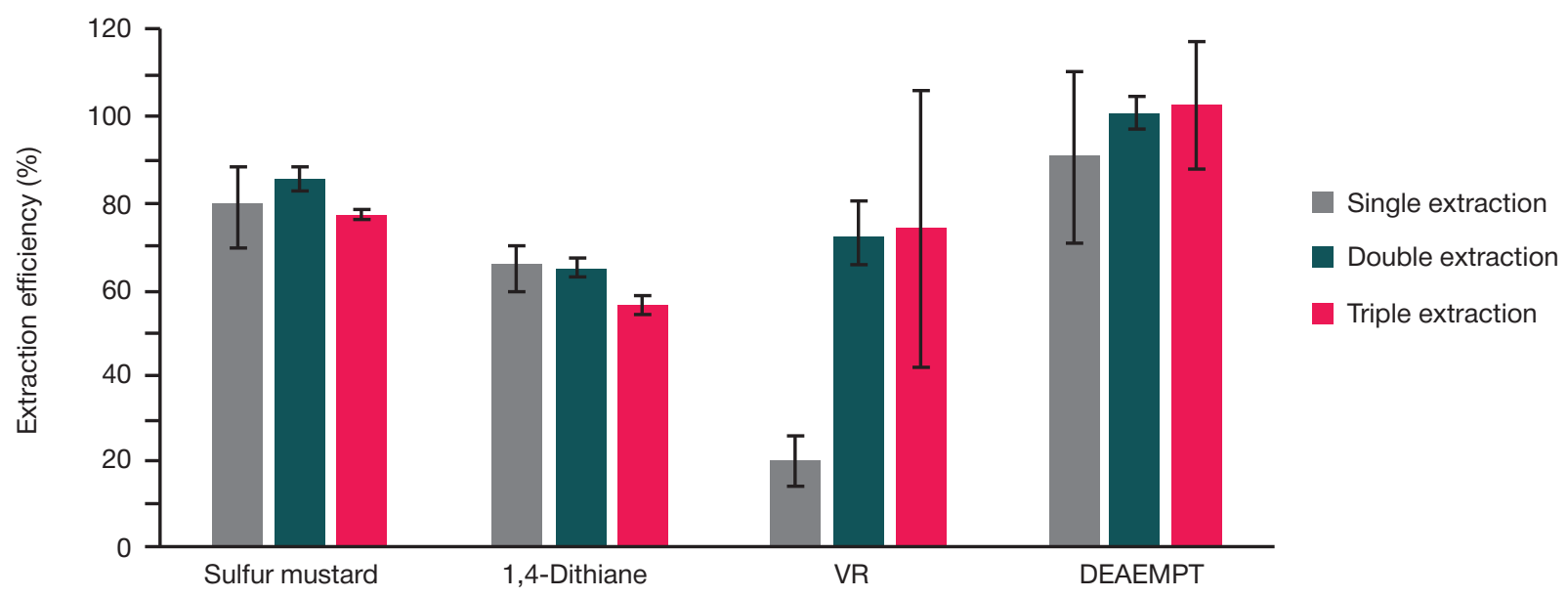

Fig. Extraction efficiency of the target compounds from gauze swabs

\section{Analysis of wipe samples taken from surfaces of equipment and infrastructure of a former CWDF}

The developed procedures for determination of sulfur mustard and 1,4-dithiane (by GC-MS/MS), VR and DEAEMPT (by HPLC-MS/MS) were applied in the context of analysis of the wipe samples taken from the elements of engineering infrastructure and building structures of a former CWDF. To test the developed approach, we analyzed wipe samples taken in the contaminated area, is not included in the conversion program.

Sulfur mustard was detected in 5 samples (out of 15), its level ranging from $2 \times 10^{-7}$ to $2 \times 10^{-6} \mathrm{mg} / \mathrm{dm}^{2} ; 1$, 4 -dithiane was identified in 12 samples (out of 15 ) its level ranging from $3 \times 10^{-6}$ to $1.5 \times 10^{-4} \mathrm{mg} / \mathrm{dm}^{2}$.

Sixty-two samples were taken in the buildings where organophosphorus agents were destroyed. VR and DEAEMPT were identified in 22 and 20 samples, respectively. The concentrations of VR and DEAEMPT on surfaces were estimated to range from $3.3 \times 10^{-6}$ to $5.2 \times 10^{-4} \mathrm{mg} / \mathrm{dm}^{2}$ and from $3.3 \times 10^{-7}$ to $1.0 \times 10^{-5} \mathrm{mg} / \mathrm{dm}^{2}$, respectively.

\section{DISCUSSION}

According to the results of the experiments, in detection of sulfur mustard and 1,4-dithiane by GC-MS/MS the matrix factor averaged at $60-80 \%$, with the number of extractions not affecting the figure significantly.

For VR and DEAEMPT the matrix factor is more pronounced. This is an expected result; it is caused by a well-known effect that hinders quantitative determinations by HPLC-MS/MS with electrospray ionization, the effect of signal suppression by the matrix [7]. The effect is mainly associated with the microdroplets charge [8] weakening during electrospraying or with saturation of the droplet surface with analyte molecules, which hinders ejection of ions from inside the droplet [9]. For ionization methods compatible with gas chromatography, and for electron ionization, in particular, the matrix effect is insignificant. In the detection of sulfur mustard and 1,4-dithiane, the matrix factor is still below $100 \%$, which is due to the increased level of noise recorded in the extract in comparison with the calibration solution. Under the given analyte extraction conditions (extraction from swabs), the matrix factor for all analytes was at least $20 \%$, which allows characterizing the analysis procedures as selective.

The results of the double extraction of sulfur mustard and 1,4-dithiane from gauze swabs are more reproducible due to elimination of such subjective factor as fullness of the solvent removal from the swab during squeezing. Third extraction in the row affected the result negatively. The volume of the extraction solvent was larger, therefore, extract concentration in the nitrogen stream took longer, which resulted in loss of analytes.

Only VR recovery changed significantly with the growing number of extractions. With single extraction, the percent recovery was $20 \%$, with double extraction it increased to $73 \%$. A third extraction did not boost the recovery efficiency of VR and DEAEMPT significantly but increased the measurement error.

The experiments allowed selecting double extraction as the optimal approach, which enables extraction of $86 \%$, $65 \%, 73 \%$, and $100 \%$ of sulfur mustard, 1,4-dithiane, VR, and DEAEMPT respectively.

The values of sulfur mustard recovery from the surfaces learned in this study are low $(0.1-9 \%)$, which is consistent with the literature data. This substance was extracted best from wipe samples taken from the surface of glazed tiles, varnished wooden surfaces and stainless steel (50\%, 30\% and 20\% respectively). In the cases of other types of surfaces (painted plasterboard, ceiling tiles, smooth cement, upholstery fabric, wooden surface untreated with varnish, escalator railings), the recovery of sulfur mustard was in the range of $0.3-7.6 \%[10]$.

Table 3. The percent recovery of sulfur mustard and 1,4-dithiane, VR and DEAEMPT from various surfaces

\begin{tabular}{|l|c|c|c|c|}
\hline \multirow{2}{*}{ Material } & \multicolumn{4}{|c|}{ Recovery, \% ( \pm SD $)$} \\
\cline { 2 - 5 } & Sulfur mustard & 1,4 -dithiane & VR & DEAEMPT \\
\hline PVC tile & $9 \pm 2$ & $5 \pm 1$ & $2.7 \pm 0.5$ & $4.8 \pm 0.1$ \\
\hline Laminate & $0.13 \pm 0.02$ & $-{ }^{*}$ & $11.8 \pm 0.3$ & $5.7 \pm 0.2$ \\
\hline Metal & $0.10 \pm 0.03$ & - & $0.8 \pm 0.1$ & $7.0 \pm 1.1$ \\
\hline
\end{tabular}

Note: * - below LOD of 1,4-dithiane $\left(5 \times 10^{-8} \mathrm{mg} / \mathrm{dm}^{2}\right)$. 
It is expedient to consider the results of VR and DEAEMPT detection in wipe samples taken from three types of surfaces in comparison with work [11], which explored the possibility of extracting degradation products of organophosphorus agents from wipe samples taken from painted plasterboard and laminate surfaces. Immediately after application, it is possible to extract $56-74 \%$ of monoalkyl esters of methylphosphonic acid (MPA) from the surface of painted plasterboard, and even after 42 days, $14-26 \%$ of the initially introduced amount can be detected. For MPA, the extraction percentage does not change from day 0 to day 42 ; within this period, it can be $7-16 \%$. All of the listed compounds are stable, polar, non-volatile. The only non-polar volatile substance in the group of analytes studied was diisopropyl ester of MPA. It could not be detected even directly after application to a painted plasterboard. A similar picture was registered in the experiment with laminate. The author of the study cited above believes it is volatility that prevents detection of the diisopropyl ester of MPA on the surface even immediately after its application.

It may take minutes or years for a toxicant to disappear from the surface by evaporation, degradation or penetration deep into the matrix with irreversible retention therein. The factors determining this duration are the chemical nature of the toxicant, which determines its stability, volatility, sorption activity, viscosity, ability to self-encapsulate, and the type of material: porosity of the structure, hydrophilic-hydrophobic properties, sorption capacity, presence of catalytically active centers, etc. The variety of the above factors and the complex nature of their interplay disallow accurate prediction of the usefulness of wipe samples in establishing the fact of contamination of an item/element etc with target compounds. Moreover, it is not possible to predict if wipe sampling, in any given case, will be possible, feasible and deliver the information expected.

The search for residual toxic substances at the former CWDF returned positive results in wipe samples taken from the surfaces of cable conduits (polymer with a dense nonabsorbent texture), lighting shades (plexiglass), painted coatings of fire points and containers made of polycarbonate. At first glance, it is incredible that toxic substances and their degradation products were detected on the surfaces long after all work related to the destruction of chemical weapons was over. We attribute this result to repeated cleaning of surfaces, first with degassing solutions, and then with large amounts of water. Apparently, degassing affected only the surface layers of materials, and water penetrated deep into the materials with a porous structure. Subsequently, pushed by leaching and capillary forces, the toxic substances and their degradation products could have migrated into the surface layers of the materials. In the process, they were partially hydrolyzed. This assumption is confirmed by the fact that surface contamination was established mainly for those materials that also proved to have their deep layers contaminated, although there was no unconditional correlation between deep and surface contamination established. Researching the literature available, we failed to find studies investigating migration of the target toxic substances from deep layers of the materials to their surface layers. Taking into account the ecological significance of this process, it is advisable to study it comprehensively.

All elements of the CWDF infrastructure that had signs of residual contamination with toxic substances were sent for destruction.

\section{CONCLUSIONS}

Wipe sampling from equipment or building structures in the context of assessment of their contamination with chemical agents allows keeping the said equipment and structures intact, while the levels of contamination thus established reflect the danger of contact with them and the related possibility of emission of volatile compounds into the air. Despite the established effect of matrix suppression, which is significant, HPLC-MS/MS is capable of detecting VR and toxic products of its hydrolysis in wipe samples, the detection being highly sensitive and direct. In case of sulfur mustard and 1,4-dithiane, GC-MS/MS proves to be highly sensitive and selective while being much less influenced by the matrix factor. After wiping, wet swabs can be sealed in an inert container, frozen and stored for a short time or transported. There is no unconditional correlation between toxicant content on the surface and in the deep layers of the materials, therefore, along with the analysis of wipe samples, it is necessary to analyze the samples of deep layers of building and other materials if there is a suspicion they may have been contaminated with toxic substances.

\section{References}

1. Saveleva El, Radilov AS, Kuznecova TA, Apraksin VF. Issledovanie sostava gazovydelenij bitumno-solevyh mass, vkljuchajushhih produkty unichtozhenija iprita. Zhurnal prikladnoj himii. 1999; 72 (9): 1501-5. Russian.

2. Munro NB, Talmage SS, Griffin GD, Waters LC, Watson AP, King JF, et al. The sources, fate, and toxicity of chemical warfare agent degradation products. Environmental Health Perspectives. 1999 107 (12): 933-74.

3. Crenshaw MD, Hayes TL, Miller TL, Shahnuon CM. Comparison of the hydrolytic stability of S-(N,N-diethylaminoethyl) isobuty methylphosphonothiolate with VX in dilute solution. J Appl Toxicol. 2001; 21 (S3-S6): 53-56.

4. Willison S. Wipe selection for the analysis of surface materials containing chemical warfare agent nitrogen mustard degradation products by ultra-high pressure liquid chromatography-tandem mass spectrometry. Journal of Chromatography A. 2012; 1270: 72-79.

5. Postanovlenie Glavnogo gosudarstvennogo sanitarnogo vracha Rossijskoj Federacii ot 28.01.2021 \# 2 «Ob utverzhdenii sanitarnyh pravil i norm SanPiN 1.2.3685-21 «Gigienicheskie normativy i

trebovanija k obespecheniju bezopasnosti i (ili) bezvrednosti dlja cheloveka faktorov sredy obitanija" (Zaregistrirovano 29.01.2021 \# 62296). Available from: https://docs.cntd.ru/ document/573500115 (data obrashhenija: 25.05.2021). Russian.

6. Saveleva EI, Leninskii MA, Vasileva IA, Karakashev GV, Samchenko NA. Opredelenie sledovyh kolichestv O-izobutil-S[(2-dijetilamino)jetil] metilfosfonotioata i toksichnogo produkta ego gidroliza metodom vysokojeffektivnoj zhidkostnoj hromatografii $\mathrm{s}$ tandemnym mass-spektrometricheskim detektirovaniem. Analitika i kontrol'. 2021; 25 (3): 43. Russian.

7. Annesley TM. Ion Suppression in Mass Spectrometry. Clin. Chem. 2003; 49: 1041-4

8. Jessome LL, Volmer DA. Ion Suppression: A Major Concern in Mass Spectrometry. LCGC North America. 2006; 24: 498-511.

9. Antignac J, Wasch K, Monteau F, Brabander H, Andre F, Le Bizec B. The ion suppression phenomenon in liquid chromatographymass spectrometry and its consequences in the field of residue analysis. Anal Chim Acta. 2005; 529: 129.

10. Hernon-Kenny LA, Behringer DL, Crenshaw MD. Comparison of latex body paint with wetted gauze wipes for sampling the 
chemical warfare agents $\mathrm{VX}$ and sulfur mustard from common indoor surfaces. Forensic Science International. 2016; 262: 143-9.

11. Wilson SA. Investigation of the Persistence of Nerve Agent

\section{Литература}

1. Савельева Е. И., Радилов А. С., Кузнецова Т. А., Апраксин В. Ф. Исследование состава газовыделений битумно-солевых масс, включающих продукты уничтожения иприта. Журнал прикладной химии. 1999; 72 (9): 1501-5.

2. Munro NB, Talmage SS, Griffin GD, Waters LC, Watson AP, King JF, et al. The sources, fate, and toxicity of chemical warfare agent degradation products. Environmental Health Perspectives. 1999. 107 (12): 933-74.

3. Crenshaw MD, Hayes TL, Miller TL, Shahnuon CM. Comparison of the hydrolytic stability of S-(N,N-diethylaminoethyl) isobutyl methylphosphonothiolate with VX in dilute solution. J Appl Toxicol. 2001; 21 (S3-S6): 53-56.

4. Willison S. Wipe selection for the analysis of surface materials containing chemical warfare agent nitrogen mustard degradation products by ultra-high pressure liquid chromatography-tandem mass spectrometry. Journal of Chromatography A. 2012; 1270: 72-79.

5. Постановление Главного государственного санитарного врача Российской Федерации от 28.01.2021 № 2 "Об утверждении санитарных правил и норм СанПиН 1.2.368521 «Гигиенические нормативы и требования к обеспечению безопасности и (или) безвредности для человека факторов среды обитания" (Зарегистрировано 29.01.2021 № 62296). Available from: https://docs.cntd.ru/document/573500115 (дата
Degradation Analytes on Surfaces through Wipe Sampling and Detection with Ultrahigh Performance Liquid ChromatographyTandem Mass Spectrometry. Anal Chem. 2015; 87: 1034-41.

обращения: 25.05.2021).

6. Савельева Е. И., Ленинский М. А., Васильева И. А., Каракашев Г. В., Самченко Н. А. Определение следовых количеств О-изобутил-S-[(2-диэтиламино)этил] метилфосфонотиоата и токсичного продукта его гидролиза методом высокоэффективной жидкостной хроматографии с тандемным масс-спектрометрическим детектированием. Аналитика и контроль. 2021; 25 (3): 43.

7. Annesley TM. Ion Suppression in Mass Spectrometry. Clin. Chem. 2003; 49: 1041-4.

8. Jessome LL, Volmer DA. Ion Suppression: A Major Concern in Mass Spectrometry. LCGC North America. 2006; 24: 498-511.

9. Antignac J, Wasch K, Monteau F, Brabander H, Andre F, Le Bizec B. The ion suppression phenomenon in liquid chromatographymass spectrometry and its consequences in the field of residue analysis. Anal Chim Acta. 2005; 529: 129.

10. Hernon-Kenny LA, Behringer DL, Crenshaw MD. Comparison of latex body paint with wetted gauze wipes for sampling the chemical warfare agents $\mathrm{VX}$ and sulfur mustard from common indoor surfaces. Forensic Science International. 2016; 262: 143-9.

11. Wilson SA. Investigation of the Persistence of Nerve Agent Degradation Analytes on Surfaces through Wipe Sampling and Detection with Ultrahigh Performance Liquid ChromatographyTandem Mass Spectrometry. Anal Chem. 2015; 87: 1034-41. 


\section{IN VIVO TOXICITY STUDY OF DIALKYL DISULPHIDES}

Kucherskoy $\mathrm{SA}^{1,2}$, Alikbaeva LA ${ }^{2}$

${ }^{1}$ Research Institute of Hygiene, Occupational Pathology and Human Ecology of the Federal Medical Biological Agency, St. Petersburg, Russia

${ }^{2}$ North-Western State Medical University named after I.I. Mechnikov, St. Petersburg, Russia

As a result of the industrial purification of hydrocarbons from mercaptans, tens of thousands of tons of dialkyl disulphides and their mixtures, the toxicity and hazard of which has not been fully understood, are accumulated annually. The exposure standards have been developed only for dimethyl disulphide. The study was aimed to define toxicometry parameters for diethyl disulphide, disulphide oil, and the mixture of dialkyl disulphides. Toxicology studies involving male outbred rats made it possible to define the median lethal doses and concentrations: diethyl disulphide - after intragastric injection $\mathrm{DL}_{50}=1575 \mathrm{mg} / \mathrm{kg}$, after the 4 -hour inhalation exposure $\mathrm{CL}_{50}=18,700 \mathrm{mg} / \mathrm{m}^{3}$, after intraperitoneal injection $\mathrm{DL}_{50}=1134 \mathrm{mg} / \mathrm{kg}$, and after skin application $\mathrm{DL}_{50}>2500 \mathrm{mg} / \mathrm{kg}$; mixture of dialkyl disulphides - after intragastric injection DL50 $=428 \mathrm{mg} / \mathrm{kg}$, after the 4-hour inhalation exposure $\mathrm{CL}_{50}=4510 \mathrm{mg} / \mathrm{m}^{3}$, after intraperitoneal injection DL $\mathrm{L}_{50}=212 \mathrm{mg} / \mathrm{kg}$, and after skin application $\mathrm{DL}_{50}>2500 \mathrm{mg} / \mathrm{kg}$; disulphide oil — after intragastric injection $\mathrm{DL}_{50}=448 \mathrm{mg} / \mathrm{kg}$, after the 4-hour inhalation exposure $\mathrm{CL}_{50}=4534 \mathrm{mg} / \mathrm{m}^{3}$, after intraperitoneal injection $\mathrm{DL}_{50}=156 \mathrm{mg} / \mathrm{kg}$, and after skin application $\mathrm{DL}_{50}>2500 \mathrm{mg} / \mathrm{kg}$. The hazard assessment for dialkyl disulphides and their mixtures was performed.

Keywords: dialkyl disulphides, dimethyl disulphide, diethyl disulphide, methylethyl disulphide, disulphide oil, acute toxicity, $\mathrm{LD}_{50}, \mathrm{LC}_{50}, \mathrm{hazard}_{\mathrm{C}} \mathrm{Class}$

Acknowlegements: we would like to thank Shkaeva IE, the leading researcher at the Research Institute of Hygiene, Occupational Pathology and Human Ecology of the FMBA, for study management, and Nikolaev Al, the leading researcher at the Research Institute of Hygiene, Occupational Pathology and Human Ecology of the FMBA, for assistance in mathematical processing of the results.

Author contribution: Kucherskoy SA — conducting toxicology studies; Alikbaeva LA — overal management.

Compliance with ethical standards: the study was approved by the Ethics Committee of the North-Western State Medical University named after I.I. Mechnikov (protocol № 8 dated November 11, 2020); laboratory animals were kept and fed in accordance with SP 2.2.1.3218-14 "Sanitary and Epidemiological Requirements for the Device, Equipment and Maintenance of Experimental Biological Clinics (Vivariums)", as well as with the "Guide for Care and Use of Laboratory Animals» (USA).

$\triangle$ Correspondence should be addressed: Semen A. Kucherskoy

Kapitolovo, str. 93, r. p. Kuzmolovsky, Vsevolozhsky r., Leningradskaya obl., 188663; kucherskoi@gpech.ru

Received: 29.05.2021 Accepted: 15.06.2021 Published online: 25.06.2021

DOI: $10.47183 /$ mes.2021.015

\section{ТОКСИЧНОСТЬ ДИАЛКИЛДИСУЛЬФИДОВ В ЭКСПЕРИМЕНТАХ IN VIVO}

\section{С. А. Кучерской ${ }^{1,2}$, Л. А. Аликбаева²}

${ }^{1}$ Научно-исследовательский институт гигиены, профпатологии и экологии человека Федерального медико-биологического агентства, Санкт-Петербург, Россия ${ }^{2}$ Северо-Западный государственный медицинский университет имени И. И. Мечникова, Санкт-Петербург, Россия

В результате промышленной очистки углеводородного сырья от меркаптанов ежегодно накопливаются десятки тысяч тонн диалкилдисульфидов и их смесей, токсичность и опасность которых в полной мере не изучена. Гигиенические нормативы разработаны только для диметилдисульфида. Целью исследования было установить параметры токсикометрии для диэтилдисульфида, “дисульфидного масла» и смеси диалкилдисульфидов. В токсикологических исследованиях на самцах беспородных крыс установлены среднесмертельные дозы и концентрации: диэтилдисульфида - при внутрижелудочном введении $\mathrm{DL}_{50}=1575$ мг/кг, при ингаляционном 4-часовом воздействии $\mathrm{CL}_{50}=18700$ мг/M³, при внутрибрюшинном введении

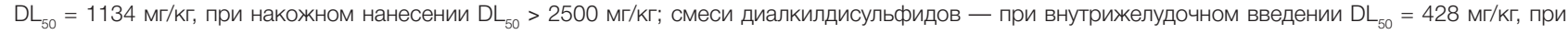

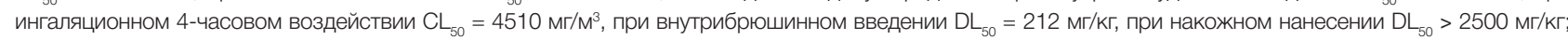
дисульфидного масла - при внутрижелудочном введении $\mathrm{DL}_{50}=448 \mathrm{Mr} / \mathrm{K}$, при ингаляционном 4-часовом воздействии $\mathrm{CL}_{50}=4534 \mathrm{Mr} / \mathrm{M}^{3}$, при внутрибрюшинном введении $\mathrm{DL}_{50}=156$ мг/кг, при накожном нанесении $\mathrm{DL}_{50}>2500$ мг/кг. Проведена оценка опасности диалкилдисульфидов и их смесей.

Ключевые слова: диалкилдисульфид, диметилдисульфид, диэтилдисульфид, метилэтилдисульфид, дисульфидное масло, острая токсичность, LD $\mathrm{LC}_{50}$, класс опасности

Благодарности: И. Е. Шкаевой - ведущему научному сотруднику НИИ ГПЭЧ ФМБА России за руководство при выполнении исследований. А. И. Николаеву - ведущему научному сотруднику НИИ ГПЭЧ ФМБА России за помощь в математической обработке результатов исследования.

Вклад авторов: С. А. Кучерской — проведение токсикологических исследований; Л. А. Аликбаева - общее руководство.

Соблюдение этических стандартов: исследование одобрено этическим комитетом СЗГМУ им. И. И. Мечникова (протокол № 8 от 11 ноября 2020 г.); условия содержания и уход за животными соответствовали нормативам СП 2.2.1.3218-14 «Санитарно-эпидемиологические требования к устройству, оборудованию и содержанию экспериментально-биологических клиник (вивариев)», а также требованиям руководства «Guide for Care and Use of Laboratory Animals» (USA).

$\bigotimes$ Для корреспонденции: Семен Александрович Кучерской

ст. Капитолово, корп. № 93, г. п. Кузьмоловский, Всеволожский район, Ленинградская область, 188663; kucherskoi@gpech.ru

Статья получена: 29.05.2021 Статья принята к печати: 15.06.2021 Опубликована онлайн: 25.06.2021

DOI: $10.47183 /$ mes.2021.015

As a result of the industrial purification of hydrocarbons from mercaptans, tens of thousands of tons of dialkyl disulphides and their mixtures are being accumulated annually [1]. Dialkyl disulphides are used in oil industry as coke formation inhibitors in pyrolysis furnaces, and sulfiding agents, the hydrotreating and hydrocracking catalysts. In agriculture, dialkyl disulphides are used as insecticides, and in food industry, these are used as flavoring agents [2-7]. Despite the widespread industrial application of dialkyl disulphides, the exposure standards for diethyl disulphide, methylethyl disulphide, and disulphide oil have not been established. In order to establish the exposure standards and to evaluate the hazards of the substances, we conducted toxicology studies of the dialkyl disulphide effects in the acute experiment. 


\section{METHODS}

Toxicity of dialkyl disulphides was assessed amidst single and repeated exposure, the study involved male outbred rats with initial weight of 220-250 g, and male mice with the weight of 20-25 g (nursery of laboratory animals "Rappolovo"; Leningrad Region). The delivered batches of animals had veterinary certificates specifying the animals' age and average weight, and indicating the absence of systemic diseases and parasitic infestation. The animals were taken to quarantine unit of the vivarium, where adaptation took place for 14 days. The animals were kept under standard housing conditions; they were given a standard diet, and had free access to water. During the quarantine period, each animal underwent daily examinations (behavior, overall condition, morbidity and mortality were evaluated). At the beginning of the experiments the animals, meeting the inclusion criteria, were randomized to groups. Animals, not meeting the inclusion criteria, were excluded from the study. Air change rate, room temperature and humidity were monitored daily. The temperature was maintained within the range of $20-24{ }^{\circ} \mathrm{C}$, the relative humidity was within the range of $50-70 \%$, the air change rate was 10 air changes per hour, and the lighting conditions were $12 \mathrm{~h}$ of light per day. The animals were euthanized in $\mathrm{CO}_{2}$ chambers.

For the experiment the animals were divided into homogeneous groups based on the body weight (8-10 animals per group); laboratory animals were labeled on an individual basis.

Acute toxicity of dialkyl disulfides was assessed by intragastric injection, intraperitoneal injection, skin application, and inhalation [8].

The studied substances were as follows:

- diethyl disulphide (DEDS) with mass fraction of parent substance at least $99 \%$, and mass fraction of dimethyl disulfide impurities at least 1\%;

- disulphide oil (DSO) with mass fraction of dimethyl disulfide of $75.14 \%$; mass fraction of diethyl disulphide of $2.08 \%$; mass fraction of methylethyl disulphide of $21.69 \%$; mass fraction of higher dialkyl disulphides $\mathrm{C}_{4}-\mathrm{C}_{8} \mathrm{~S}_{2} \mathrm{H}_{10}-\mathrm{H}_{22} \approx 1 \%$.

- mixture of dialkyl disulphides with mass fraction of DMDS of $26.4 \%$; mass fraction of MEDS of $53.0 \%$; mass fraction of DEDS of $20.7 \%$;

Physical and chemical properties of dialkyl disulphides are presented in Table 1 [9].
Intragastric injections of the substances (at a dose of 75-2000 mg/kg) were performed using the atraumatic probe; vegetable oil was used as a solvent.

The inhalation exposure modeling was performed in the chambers with a volume of $600 \mathrm{dm}^{3}$. The experimental animals were exposed to the following concentrations of dialkyl disulphide vapors: diethyl disulphide 10,000-22,000 mg/m³ disulphide oil $4000-5000 \mathrm{mg} / \mathrm{m}^{3}$; mixture of DADS 3800-6000 $\mathrm{mg} / \mathrm{m}^{3}$. The exposure time for a single inhalation exposure was $2 \mathrm{~h}$ in mice, and $4 \mathrm{~h}$ in rats.

The vapor concentrations in the air within the exposure chambers were controlled by gas chromatography with flame ionization detection.

During the acute experiments, the duration of observation after the exposure to the substance was 14 days. The overall condition, behavior, appearance, and response to external stimuli were evaluated in experimental animals. Clinical manifestations of poisoning were registered. In end of observation period necropsy was performed, the macroscopic examination of internal organs.

\section{RESULTS}

Intragastric injection of the mixture containing DADS and DSO resulted in the animals' death of pulmonary edema, mainly during the first day. Intragastric injection of DEDS resulted in the animals' death delayed until day 7 . Clinical manifestations of acute dialkyl disulphide intoxication were similar: hypo- or adynamia of experimental animals, and decreased respiration rate. Macroscopic examination of the dead animals' internal organs revealed the following: brown lung induration and pulmonary hemorrhage, tracheal froth, dark brown spleen and kidneys, fine liver surface nodularity.

The overall appearance of animals, which survived acute intoxication, was the same as of controls throughout the observation period.

Based on the acute toxicity parameters defined for intragastric injection, the studied dialkyl disulphides are moderately hazardous substances (hazard class 3 [10]). DEDS is assigned hazard class 4 , and the mixture of DADS and disulphide oil is assigned hazard class 3 [11] (Table 2).

The studied substances are supported as mildly hazardous by the species ratio values:

DEDS species ratio: $1575 / 1565=1.006$

Table 1. Physical and chemical properties of dialkyl disulphide samples

\begin{tabular}{|c|c|c|c|}
\hline \multirow{2}{*}{ Indicator } & \multicolumn{3}{|c|}{ Dialkyl disulphides } \\
\hline & DMDS & MEDS & DEDS \\
\hline Chemical formula & $\mathrm{CH}_{3} \mathrm{SSCH}_{3}$ & $\mathrm{CH}_{3} \mathrm{SSC}_{2} \mathrm{H}_{5}$ & $\mathrm{C}_{2} \mathrm{H}_{5} \mathrm{SSC}_{2} \mathrm{H}_{5}$ \\
\hline № CAS & $624-92-0$ & $20333-39-5$ & $110-81-6$ \\
\hline Physical appearance & pale yellow transparent liquid & oleaginous fluid & oleaginous fluid \\
\hline Molecular mass, $\mathrm{g} / \mathrm{mol}$ & 94.2 & 108.23 & 122.25 \\
\hline Density, $\mathrm{g} / \mathrm{cm}^{3}$ & 1.057 & 1.022 & 0.993 \\
\hline Boiling point, ${ }^{\circ} \mathrm{C}$ & 109.7 & 131.6 & 154.1 \\
\hline Refractive index & 1.5259 & 1.5146 & 1.506 \\
\hline Sulphur content, wt\% & 68.09 & 59.26 & 52.46 \\
\hline \multicolumn{4}{|c|}{ Solubility } \\
\hline Water & insoluble & insoluble & sparingly soluble \\
\hline Diethyl ether & soluble & soluble & mixing \\
\hline Ethanol & soluble & soluble & mixing \\
\hline
\end{tabular}

Note: DMDS — dimethyl disulphide; MEDS — methylethyl disulphide; DEDS — diethyl disulphide. 
Table 2. Dialkyl disulphide acute toxicity parameters with intragastric injection

\begin{tabular}{|c|c|c|c|}
\hline \multirow{3}{*}{ Animal species } & \multicolumn{3}{|c|}{ Lethal doses, mg/kg } \\
\hline & $\mathrm{LD}_{16}$ & $\mathrm{LD}_{50}$ & $\mathrm{LD}_{84}$ \\
\hline & \multicolumn{3}{|c|}{ Diethyl disulphide } \\
\hline Male mice & 942 & $1565 \pm 370$ & 2601 \\
\hline Male rats & 1384 & $1575 \pm 91$ & 1793 \\
\hline \multicolumn{4}{|c|}{ Mixture of DADS } \\
\hline Male mice & 244 & $435 \pm 118$ & 775 \\
\hline Male rats & 307 & $428 \pm 83$ & 597 \\
\hline \multicolumn{4}{|c|}{ Disulphide oil } \\
\hline Male mice & 276 & $381 \pm 56$ & 527 \\
\hline Male rats & 265 & $448 \pm 142$ & 759 \\
\hline
\end{tabular}

Mixture of DADS species ratio: $428 / 435=0.98$.

DSO species ratio: $448 / 381=1.17$.

Upon intraperitoneal injection in rats the acute toxicity parameters has been defined (Table 3), supporting these compounds as being moderately hazardous.

After intraperitoneal injection of the mixture containing DADS and DSO, adynamia occurred within 5 minutes, and the respiration rate decreased in experimental animals. The animals died of respiratory arrest 30-60 min after administration of the substance.

After intraperitoneal injection of DEDS, the experimental animals exhibited psychomotor retardation during one hour, they did not respond to external stimuli. After $4-5 \mathrm{~h}$ the overall appearance of experimental animals was the same as of controls. The animals died of pulmonary edema during the first day after administration of DEDS.

Masroscopic features of internal organs were the same as in case of intragastric injection.

Based on the acute toxicity parameters defined for inhalation exposure, the mixture of DADS and disulphide oil are assigned hazard class 2 [10] and 3 [11]. Based on the $\mathrm{CL}_{50}$ value, DEDS is assigned hazard class 3 [10] and 4 [11] (Table 4).

No significant species differences were defined for dialkyl disulphide inhalation poisoning.

The index of potential inhalation toxicity (IPITac) indicated low hazard upon single inhalation exposure to DEDS (IPITac = $24999.3 / 18,700=1.33$ ), and moderate hazard upon exposure to the mixture of DADS (IPITac $=74004.5 / 4534=16.3)$, and disulphide oil (IPITac $=105336.5 / 4510=23.3)$.

Clinical manidestations of acute inhalation poisoning with dialkyl disulphide vapors were as follows: hypo- or adynamia of experimental animals, signs of hypoxia (moderate cyanosis of faces and paws), and breathing problems. The periods of decreased motor activity were followed by periods of increased motor activity. The animals died of pulmonary edema due to exposure to the mixture of DADS and DSO within $24 \mathrm{~h}$ of inhalation exposure; when exposed to DEDS, the animals died mostly on day 3-5 of observation. Masroscopic features of internal organs were the same as in case of intragastric injection.
The overall appearance and behavior of animal survivors being monitored for 14 days after exposure were the same as those of controls.

It was found that the mixture of DADS and DSO was fatal for a part of mice during the 2-hour exposure with the 2/3 of the tail length placed into test tubes filled with substances; however, DEDS was not fatal for experimental mice.

Upon dermal exposure, the following median lethal doses $\left(D L_{50}\right)$ were defined for experimental rats: mixture of DADS 7400 (5690; 9620) mg/kg, DSO - 3400 (2345; 4930) mg/kg. Based on the median lethal doses upon skin application, the studied substances were assigned hazard class 4 [10]. Skin application of DEDS for $4 \mathrm{~h}$ was never fatal for experimental rats. No signs of skin irritation were observed. Clinical manifestations of acute poisoning upon dermal exposure of experimental animals to dialkyl disulfides were the same as in case of intragastric injection.

The study results were indicative of the substances being hazardous in contact with skin.

After application of one drop of the studied substance on the mucous membrane of the rat's eye, the irritant effect in the form of hyperemia was observed. Hyperemia vanished 1-2 days later, and further observation demonstrated that the experimental rats had the same overall appearance and showed the same dynamic changes of body weight as the controls.

\section{DISCUSSION}

The results obtained for acute oral toxicity of disulfide oil are within a factor of three of the literature data $(1590 \mathrm{mg} / \mathrm{kg}$ reported by Morgott et al., and $428 \mathrm{mg} / \mathrm{kg}$ in our studies) [5], which could indicate different composition of disulphide oil, the use of different experimental animal species, or the use of different solvent for intragastric injection. The article by Morgott et al. [5] refers to the unpublished results obtained at the IIT Research Institute. There is no information about this source in the Scopus, and PubMed databases. The inhalation toxicity data also differ: Morgott et al. [5] report it to be greater than $4840 \mathrm{mg} / \mathrm{m}^{3}$; in our studies $\mathrm{CL}_{50}$ of $4534 \mathrm{mg} / \mathrm{m}^{3}$ was

Table 3. Dialkyl disulphide acute toxicity parameters with single intraperitoneal injection in male rats $(n=10)$

\begin{tabular}{|l|c|c|c|}
\hline \multirow{2}{*}{\multicolumn{2}{|c|}{ Substances }} & \multicolumn{3}{|c|}{ Lethal doses, $\mathrm{mg} / \mathrm{kg}$} \\
\cline { 2 - 4 } & $\mathrm{LD}_{16}$ & $\mathrm{LD}_{50}$ & $1575 \pm 91$ \\
\hline Diethyl disulphide & 1384 & $212 \pm 11$ & 1793 \\
\hline Mixture of DADS & 187 & $156 \pm 33$ & 240 \\
\hline Disulphide oil & 98 & 248 \\
\hline
\end{tabular}


Table 4. Dialkyl disulphide acute toxicity parameters with single inhalation exposure

\begin{tabular}{|c|c|c|c|}
\hline \multirow{2}{*}{ Animal species } & \multicolumn{3}{|c|}{ Lethal concentrations, $\mathrm{mg} / \mathrm{m}^{3}$} \\
\hline & $\mathrm{CL}_{16}$ & $\mathrm{CL}_{50}$ & $\mathrm{CL}_{84}$ \\
\hline \multicolumn{4}{|c|}{ Diethyl disulphide } \\
\hline Male mice & 17630 & $18125 \pm 515$ & 19930 \\
\hline Male rats & 17800 & $18700 \pm 556$ & 19730 \\
\hline \multicolumn{4}{|c|}{ Mixture of DADS } \\
\hline Male mice & 3900 & $4200 \pm 190$ & 4750 \\
\hline Male rats & 3300 & $4534 \pm 519$ & 5120 \\
\hline \multicolumn{4}{|c|}{ Disulphide oil } \\
\hline Male mice & 3900 & $4200 \pm 180$ & 4700 \\
\hline Male rats & 4400 & $4510 \pm 60$ & 4600 \\
\hline
\end{tabular}

established. However, the acute toxicity data for disulfide oil are close to data obtained by Morgott et al. for dimethyl disulfide.

\section{CONCLUSION}

As a result of the experimental studies, the acute toxicity parameters were defined for intragastric injection and inhalation exposure: for DEDS, $\mathrm{DL}_{50}$ was $1575 \mathrm{mg} / \mathrm{kg}$, and $\mathrm{CL}_{50}$ was $18,700 \mathrm{mg} / \mathrm{m}^{3}$; for the mixture of DADS, $\mathrm{DL}_{50}$ was $448 \mathrm{mg} / \mathrm{kg}$, and $\mathrm{CL}_{50}=4510 \mathrm{mg} / \mathrm{m}^{3}$; for $\mathrm{DSO}, \mathrm{DL}_{50}$ was $428 \mathrm{mg} / \mathrm{kg}$, and $\mathrm{CL}_{50}=4534 \mathrm{mg} / \mathrm{m}^{3}$. The median lethal dose $\left(\mathrm{DL}_{50}\right)$ for dermal exposure to the mixture of DADS was $7400 \mathrm{mg} / \mathrm{kg}$, and for DSO it was $3400 \mathrm{mg} / \mathrm{kg}$; DEDS was not fatal in contact with skin. The data obtained show that dialkyl disulfides are the moderately hazardous substances upon single intragastric injection, inhalation exposure, and skin application. Comparison of the studied substances with dimethyl disulfide (DMDS) by toxicity has shown that based on the toxicometry parameters, DEDS is about 9 times less toxic upon intragastric injection, and 3 times less toxic upon single inhalation exposure, compared to DMDS. Comparison of the mixture of DADS and DSO with DMDS has revealed similar inhalation toxicity. The mixture of DADS and disulphide oil is 2 times less toxic upon intragastric injection compared to DMDS. Comparison of DSO and DADS mixture toxicity has shown that impurities do not affect the toxicometry parameters. These toxicometry parameters would be used to define the hazard class and to establish the dialkyl disulfide exposure standards. To date, the exposure standards have been developed only for dimethyl disulphide.

\section{References}

1. Rahimov TH. Sovershenstvovanie processa pervichnoj pererabotk nefti i gazovogo kondensata s polucheniem serosoderzhashhih soedinenij i uglevodorodov [dissertacija]. Ufa, 2020. Russian.

2. Meshhakova NM, Benemanskij V. Ocenka biologicheskogo dejstvija dimetildisul'fida s uchetom specificheskih otdalennyh jeffektov. Bjulleten' VSNC SO RAMN. 2005; 2: 209-12. Russian.

3. Jurkevich ES, Prismotrov YuA. Nauchnoe obosnovanie orientirovochno bezopasnogo urovnja vozdejstvija dimetildisul'fida $\vee$ vozduhe rabochej zony. Zdorov'e i okruzhajushhaja sreda. 2009; 13: 51521. Russian.

4. Obzor rynka disul'fidnogo masla v Rossii. M.: Infomajn, 2012; 107 s. Russian.

5. Morgott D, Lewis C, Bootman J, Banton M. Disulfide oil hazard assessment using categorical analysis and a mode of action determination. Int J Toxicol. 2014; 33 (1): 181-98.

6. Munday R. Harmful and beneficial effects of organic monosulfides,

\section{Литература}

1. Рахимов Т. Х. Совершенствование процесса первичной переработки нефти и газового конденсата с получением серосодержащих соединений и углеводородов [диссертация]. Уфра, 2020

2. Мещакова Н. М., Бенеманский В. В. Оценка биологического действия диметилдисульфида с учетом специфических отдаленных эффектов. Бюллетень ВСНЦ СО РАМН. 2005; 2: 209-12

3. Юркевич Е. С., Присмотров Ю. А. Научное обоснование ориентировочно безопасного уровня воздействия диметилдисульфида в воздухе рабочей зоны. Здоровье и окружающая среда. 2009; 13: 515-21.

4. Обзор рынка дисульфидного масла в России. М.: Инфомайн, 2012; 107 c.

5. Morgott D, Lewis C, Bootman J, Banton M. Disulfide oil hazard assessment using categorical analysis and a mode of action determination. Int J Toxicol. 2014; 33 (1): 181-98.

6. Munday R. Harmful and beneficial effects of organic monosulfides, disulfides, and polysulfides in animals and humans. Chem Res Toxicol. 2012; 25 (1): 47-60.

7. Valavanidis A, Vlahogianni T, Dassenakis M, Scoullos M. Molecular biomarkers of oxidative stress in aquatic organisms in relation to toxic environmental pollutants. Ecotoxicol Environ Saf. 2006; 64 (2): 178-89. 
8. Дюсенгалиев К. И. Физико-химические характеристики субститутов дисульфидного масла углеводородного сырья. Нефтяное дело. 2016; 5: 125-39.

9. Методические указания для определения ориентировочных безопасных уровней воздействия (ОБУВ) в атмосферном воздухе населенных мест. М., 1982; 17 с.

10. Вредные вещества: классификация и общие требования безопасности. ГОСТ 12.1.007.-76. М., 1976; 6 с.

11. Классификация опасности химической продукции. Общие требования. ГОСТ 32419-2013. М.: Стандартинформ, 2014; 25 с. 


\title{
EXPERIMENTAL JUSTIFICATION OF THE MAXIMUM POSSIBLE CONCENTRATION OF DICHLOROHEXAFLUOROBUTENE IN A WORKING AREA
}

Shkaeva IE, Dulov SA, Nikulina OS, Solnceva SA $\bowtie$, Zemlyanoi AV

Research Institute of Hygiene, Occupational Pathology and Human Ecology of the Federal Medical Biological Agency, St. Petersburg, Russia

To date, there have been no exposure standards for air concentrations of 1,4-dichlorohexafluorobutene (DCHF) in the work areas. The study was aimed to assess the toxicity of DCHF and to evaluate health hazard in acute, subacute, and chronic experiments. It was found that the substance was highly hazardous, $\mathrm{DL}_{50}$ in mice after intragastric injection was $79.0 \mathrm{mg} / \mathrm{kg}, \mathrm{CL}_{50}$ was $229.0 \mathrm{mg} / \mathrm{m}^{3}$, and in rats these values were $86,0 \mathrm{mg} / \mathrm{kg}$ and $670,0 \mathrm{mg} / \mathrm{m}^{3}$. In animals, DCHF had a moderate local irritative effect on animal skin and ocular mucous membranes, as well as the skin resorptive effect. The $18.2 \mathrm{mg} / \mathrm{m}^{3}$ threshold limit concentration for a single inhalation exposure to DCHF was defined based on the changes in behavior responses and blood parameters. The 30-day subacute inhalation experiment revealed the pronounced cumulative effect of the substance. The 4-months chronic inhalation study showed that the exposure of experimental rats to $16.8 \mathrm{mg} / \mathrm{m}^{3} \mathrm{concentration}$ of DCHF resulted in impaired function of central nervous system and cardiac activity, altered hematologic, biochemical, acid-base, and blood gas values, as well as in morphological alterations in lungs, which persisted after the 30-day recovery period. The chronic exposure threshold defined for DCHF was $2.2 \mathrm{mg} / \mathrm{m}^{3}$, and the defined no observable effect level was $0.24 \mathrm{mg} / \mathrm{m}^{3}$. Based on the study results, the maximum permissible concentration of DCHF in the air of the working area of $0.2 \mathrm{mg} / \mathrm{m}^{3}$ was confirmed and approved, the substance was assigned hazard class 2, vapor + aerosol + (specific protection of skin and eyes required). Gas chromatographic method using electron-capture detection for determination of DCHF mass air concentration in the work areas has been developed and approved.

Keywords: freon RL316, toxicity, hazard, exposure standard, air quality in the work areas

Author contribution: Shkaeva IE — study planning, literature analysis, data interpretation, rationale for setting the exposure standard, manuscript writing; Dulov SA — study planning, overall management; Nikulina OS, Solnceva SA — literature analysis, toxicological testing, data acquisition and analysis, manuscript writing; Zemlyanoi AV — research management, manuscript writing.

Compliance with ethical standards: laboratory animals were kept and fed in accordance with "Guidelines for Keeping Laboratory Animals in Vivariums of Research Institutes and Educational Institutions" (RD-APC 3.10.07.02-09 dated 15.12.2009), as well as with "Sanitary and Epidemiological Requirements for the Device, Equipment and Maintenance of Experimental Biological Clinics (Vivariums)" (SP 2.2.1.3218-14 dated 29.08.2014).

$\triangle$ Correspondence should be addressed: Svelana A. Solnceva

Kapitolovo, str. 93, r.p. Kuzmolovsky, Vsevolozhsky r., Leningradskaja obl., 188663; solnceva.74@inbox.ru

Received: 29.05.2021 Accepted: 13.06.2021 Published online: 23.06.2021

DOI: $10.47183 /$ mes.2021.014

\section{ЭКСПЕРИМЕНТАЛЬНОЕ ОБОСНОВАНИЕ ПРЕДЕЛЬНО ДОПУСТИМОЙ КОНЦЕНТРАЦИИ ДИХЛОРГЕКСАФТОРБУТЕНА В ВОЗДУХЕ РАБОЧЕЙ ЗОНЫ}

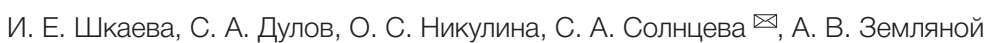

Научно-исследовательский институт гигиены, профпатологии и экологии человека Федерального медико-биологического агентства, Санкт-Петербург, Россия

До настоящего времени отсутствовал гигиенический норматив содержания 1,4-дихлоргексафторбутена (ДХГФ) в воздухе рабочей зоны. Целью работы было провести оценку токсичности и опасности ДХГФ в острых, подострых и хроническом экспериментах. Установлено, что вещество

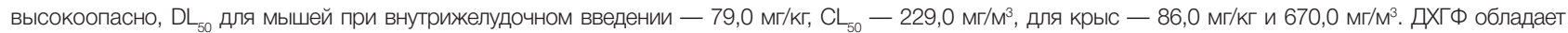
умеренным местным раздражающим действием на кожу животных и слизистые оболочки глаз и кожно-резорбтивным эффектом. Порог однократного ингаляционного действия ДХГФ обоснован на уровне 18,2 мг/м³ по изменению параметров поведенческих реакций и показателей состояния крови. В подостром 30-суточном ингаляционном эксперименте обнаружены выраженные кумулятивные свойства вещества. В хроническом четырехмесячном ингаляционном эксперименте воздействие ДХГФ в концентрации 16,8 мг/м³ вызывало у подопытных крыс нарушение функционального состояния центральной нервной системы, сердечной деятельности, изменения гематологических, биохимических показателей, кислотно-основного состояния и газообмена крови, а также морфологические изменения в легких, которые сохранялись через 30 суток восстановительного периода. Порог

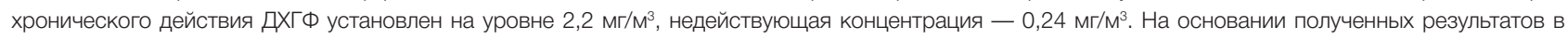
качестве предельно допустимой концентрации ДГХФ в воздухе рабочей зоны обоснована и утверждена величина 0,2 мг/М³ , 2-й класс опасности, пары + аэрозоль + (требуется специальная защита кожи и глаз). Для измерения массовой концентрации ДХГФ в воздухе рабочей зоны разработан и утвержден газохроматографический метод с электронно-захватным детектированием.

Ключевые слова: хладон RL316, токсичность, опасность, гигиенический норматив, воздух рабочей зоны

Вклад авторов: И. Е. Шкаева - планирование исследования, анализ литературы, интерпретация данных, обоснование норматива, подготовка рукописи; С. А. Дулов - планирование исследования, общее руководство; О. С. Никулина, С. А. Солнцева - анализ литературы, проведение токсикологических исследований, сбор и анализ данных, подготовка рукописи; А. В. Земляной - руководство проводимыми исследованиями, подготовка рукописи.

Соблюдение этических стандартов: содержание и кормление лабораторных животных осуществляли в соответствии с «Методическими рекомендациями по содержанию лабораторных животных в вивариях научно-исследовательских институтов и учебных заведений» (РД-АПК 3.10.07.02-09 от 15.12.2009 г.), а также в соответствии с «Санитарно-эпидемиологическими требованиями к устройству, оборудованию и содержанию экспериментально-биологических клиник (вивариев)» (СП 2.2.1.3218-14 от 29.08.2014).

$\bowtie$ Для корреспонденции: Светлана Андреевна Солнцева

ст. Капитолово, корп. 93, г.п. Кузьмоловский, 188663, Всеволожский район, Ленинградская обл.; solnceva.74@inbox.ru

Статья получена: 29.05.2021 Статья принята к печати: 13.06.2021 Опубликована онлайн: 23.06.2021

DOI: $10.47183 /$ mes.2021.014 
The compound, referred to as 1,4-dichlorohexafluorobutene (DCHF), is intended to be used as solvent, refrigerant or reagent for synthesis of perfluorobutadiene. Among the fluorinecontaining hydrocarbon compounds, which include DCHF, toxicity increases with introduction of the chlorine atom into the parent molecule, and due to presence of double bonds [1, 2].

Currently, the best-known structural isomer of DCHF is 2,3-dichloro-1,1,1,4,4,4-hexafluorobutene [3-7], which is classified as highly toxic hazardous substance [8-12]: it causes pulmonary edema, nervous system damage, produces hepatotoxic and nephrotoxic effects, and also penetrates intact skin, exerting a pronounced skin resorptive effect. The researchers attribute the toxic effects of DCHF to dehalogenation processes, and to formation of metabolites that disrupt metabolic pathways.

So far, there was extremely limited information about the DCHF toxicity, and the DCHF exposure standards for the air in the work areas and environmental objects (ambient air, water, soil) have not yet been developed $[14,15]$

The study was aimed at experimental confirmation of maximum permissible air concentrations of DCHF in the work areas.

\section{METHODS}

According to its physical and chemical properties, 1,4-dichlorohexafluorobutene-2 (synonims: DCHF, freon RL316; chemical formula: $\mathrm{C}_{4} \mathrm{Cl}_{2} \mathrm{~F}_{6}$; № CAS 360-88-3) is a clear colorless liquid with weak characteristic odor, having the relative molecular mass of 232.94 , boiling point of $63 \pm 5$ ${ }^{\circ} \mathrm{C}$, and melting point of $-75^{\circ} \mathrm{C}[1-2]$.

The studies were performed in accordance with guidelines [3-5] in outbred animals (white rats and mice with initial body weight of 220-250 $\mathrm{g}$ and 20-25 g respectively), obtained from the nursery of laboratory animals "Rappolovo" (Leningrad Region). The delivered batches of animals had veterinary certificates specifying the animals' age and average weight, and indicating the absence of systemic diseases and parasitic infestation

The animals were taken to quarantine unit of the vivarium, where they had been monitored for two weeks. The animals were kept under standard housing conditions; they were given a standard diet, and had free access to water. During the quarantine, each animal underwent daily examinations (behavior, overall condition, morbidity and mortality were evaluated). Cages with animals were in separate rooms. Lighting conditions: $12 \mathrm{~h}$ - light, $12 \mathrm{~h}$ - dark; the ambient temperature was maintained within the range of $19-25^{\circ} \mathrm{C}$, the relative humidity was within the range of $50-70 \%$. Temperature and humidity were recorded daily. For the study the animals were divided into homogeneous groups, 8-10 animals per group

Toxicity of DCHF was assessed amidst single and repeated exposure. The risk of acute poisoning with DCHF was defined for ingestion and inhalation, as well as for skin contact. In order to assess the irritant and skin resorptive effects, DCHF was applied to the clipped backs of rats, and the tails of the mice were placed into test tubes with the substance at 2/3 of the height (the exposure time in mice was $2 \mathrm{~h}$, and in rats it was $4 \mathrm{~h}$ ).

The inhalation exposure of experimental animals to DCHF was provided both under static conditions with free evaporation of the substance at room temperature, and in the specialized dynamic sealed stainless steel chambers with a volume of $600 \mathrm{dm}^{3}$. The specified concentrations of the substance were obtained with the calculated doses introduced into the steam generator. The exposure time in a single exposure was $2 \mathrm{~h}$ in mice, and $4 \mathrm{~h}$ in rats.

Cumulative properties of the substance were assessed in a subchronic experiment: the experimental rats had been exposed to DCHF by inhalation for 30 days, $4 \mathrm{~h}$ per day (except weekends).

Furthermore, chronic intoxication with DCHF was maintained during 4 months ( $4 \mathrm{~h}$ per day, except weekends) followed by monitoring of experimental rats during the 30-day recovery period.

DCHF concentrations in the air within the exposure chambers were controlled by the specially developed gas chromatography method.

The overall condition of experimental animals was evaluated using a set of methods that made it possible to detect changes at multiple structural and functional levels. Integral, physiological, hematological, biochemical, and morphological indicators were used. Plasma levels of DCHF and metabolites in experimental rats were defined by gas chromatography-mass spectrometry, and high performance liquid chromatography coupled with high resolution mass-selective detection.

Statistical analysis was performed based on comparison of mean values of the experimental and control groups. Chisquared $\left(\chi^{2}\right)$ and Fisher's exact tests were used for assessment of differences between discrete data. The differences were considered significant when $p<0.05$. Statistical data processing was performed using the Prizm 5 software.

\section{RESULTS}

The study found that based on acute toxicity DCHF was a highly toxic substance: $\mathrm{CL}_{50}$ in mice was $229.0 \pm 10.4 \mathrm{mg} / \mathrm{m}^{3}$, and in rats it was $670 \pm 32.0 \mathrm{mg} / \mathrm{m}^{3} ; \mathrm{DL}_{50}$ was $79.0 \pm 11.1 \mathrm{mg} / \mathrm{kg}$ and $86.0 \pm 16.0 \mathrm{mg} / \mathrm{kg}$ respectively. Clinical manifestations of acute DCHF poisoning were as follows: short-term hyperkinesia, reduced respiratory rate, coordination impairment, adynamia, tonic-clonic seizures. The experimental animals died mainly on day 1-3 of exposure to the substance. Animal autopsies showed the following: lungs - atelectases, foci of hemorrhage, alveolar edema, patchy emphysema and bronchopneumonia, hemorrhagic infarction; kidney and liver — fatty degeneration of parenchyma; after acute freon intoxication by inhalation, DCHF and metabolites (acetylcysteine adduct and methyl sulfide) were detected in animal blood plasma and urine.

It was found, that DCHF had a moderate local irritative effect on animal skin and ocular mucous membranes, together with the skin resorptive effect. The threshold limit concentration for a single inhalation exposure (Limac) to DCHF of $18.2 \mathrm{mg} / \mathrm{m}^{3}$ was calculated based on changes in behavioral responses and acid-base balance of blood. The 30-day subacute inhalation experiment revealed the pronounced cumulative effect of DCHF.

For the purpose of studying the chronic intoxication manifestation and assessing the risk of long-term intake, the experimental animals had been exposed to DCHF by inhalation for 4 months, $4 \mathrm{~h}$ per day (except weekends). The following concentrations of DCHF were used: $16.8 \pm 3.8 ; 2.2 \pm 0.9$, and $0.24 \pm 0.09 \mathrm{mg} / \mathrm{m}^{3}$.

Dynamic testing of the animals was performed throughout the chronic experiment and 30 days after the inhalation exposure to DCHF (recovery period).

Prolonged exposure of experimental rats to DCHF concentration of $16.8 \mathrm{mg} / \mathrm{m}^{3}$ resulted in impaired CNS function, mainly in altered exploratory behaviors.

The significant increase in the vertical activity was observed in experimental rats after 14 days of the experiment (4.2 \pm 1.3 
in the experimental group, $1.5 \pm 0.8$ in the control group). The maximum changes $(6.2 \pm 1.2$ in the experimental group, $1.8 \pm 0.8$ in the control group) were detected after 30 days of exposure to DCHF. The significantly increased value of the parameter persisted throughout the 2-months exposure to the substance concentration of $16.8 \mathrm{mg} / \mathrm{m} 3$. After 90 days of the experiment the vertical activity of the treated animals became close to values of the controls. However, by the end of 4-months exposure to DCHF, this indicator significantly increased by $253 \%$.

Similar direction of changes was observed when studying the emotional behavior of experimental animals. The dynamic changes in grooming behavior were characterized by maximum increase of the indicator after 30 and 60 days of the experiment, 2.5 and 3 times compared to controls respectively, and the decrease to control level by day 90 of exposure to DCHF concentration of $16.8 \mathrm{mg} / \mathrm{m}^{3}$. By the end of chronic experiment, the direction of changes in grooming behavior of experimental animals remained the same, however, it was less evident (increase by $80 \%$ compared to controls).

The 4-months inhalation exposure of experimental animals to the substance resulted in cardiac abnormalities. Based on electrocardiographic findings, the significant decrease in the $P$ wave height $(p<0.05)$ indicative of atrial dysfunction was detected after 30 days of experiment. The decrease in the $\mathrm{R}$ wave height by $43.2 \%$ compared to controls after 30 days, and by $25.7 \%$ by the end of the experiment was indicative of suppressed ventricular bioelectric activity. However, after 90 days of experiment the $\mathrm{R}$ wave height was the same as in control animals.

The S wave height on ECG of experimental rats decreased by $41.9 \%$ compared to controls after 30 days, and by $24.5 \%$ by day 120 of exposure to DCHF concentration of $16.8 \mathrm{mg} / \mathrm{m}^{3}$. Depression of $\mathrm{P}, \mathrm{R}, \mathrm{S}$, and $\mathrm{T}$ waves, as well as the prolonged QT and ST intervals in experimental rats are indicative of the cardiac conduction disorder, which may result from myocardial hypoxia associated with chronic inhalation exposure to the substance. At the same time, it should be noted that there has been an improvement in ECG readings on days 60-90 of the experiment, which demonstrates the implementation of compensatory and adaptive processes, as well as the animal adaptation to substance exposure. However, by day 120 of exposure to DCHF concentration of $16.8 \mathrm{mg} / \mathrm{m}^{3}$, cardiac depression was observed, which was indicative of possible compensatory processes disruption associated with prolonged exposure to this concentration of the substance.

There were no significant differences in heart rate and respiratory rate between the experimental rats and the controls.

After 30 and 60 days of exposure to the substance, the significant $(p<0.05)$ decrease in total hemoglobin and mean corpuscular hemoglobin was observed.

The changes in the leukocyte formula of experimental rats included the increase in the number of lymphocytes by $31.5 \%$ compared to controls after 30 days, and by $91.8 \%$ after 60 days of the experiment.

Analysis of the acid-base status in experimental animals showed that inhalation exposure to DCHF concentration of $16.8 \mathrm{mg} / \mathrm{m}^{3}$ resulted in changes in bicarbonate buffer system in the form of the decrease in base excess of the extracellular fluid (BEecf) by $46.6 \%$ compared to control rats after 30 days of the experiment. The base excess of blood (Beb) in experimental rats of this group significantly decreased by $36.4 \%$ compared to controls on day 7 , and by $40 \%$ after 30 days of the experiment.

At the same time, there was a significant decrease in standard bicarbonate value. With an increase in the DCHF exposure time up to 60 days, the trend towards an increase in base excess of the extracellular fluid (BEecf) by $23.5 \%$ compared to controls, and base excess of blood (Beb) by $28 \%$ was observed.

By the end of 4-months inhalation exposure to DCHF the acid-base status of experimental rats was the same as of controls. Since there were no significant changes in blood $\mathrm{pH}$, the experimental data obtained were indicative of compensatory and adaptive processes activation associated with exposure to DCHF during the first 30 days of the chronic experiment.

When studying blood gas exchange in experimental animals during the 60-day exposure to DCHF, the decrease in oxygen saturation $\left(\mathrm{SO}_{2}\right)$ and partial pressure of oxygen $\left(\mathrm{pO}_{2}\right)$ was observed. After 60 days of the experiment, in experimental rats of the same group, there was a decrease in alveolar oxygen tension with simultaneous increase in partial pressure of carbon dioxide. The longer lasting inhalation exposure to DCHF concentration of $16.8 \mathrm{mg} / \mathrm{m}^{3}$ resulted in no significant changes of blood gas exchange in experimental rats.

Biochemical analysis showed that prolonged exposure of experimental rats to DCHF concentration of $16.8 \mathrm{mg} / \mathrm{m}^{3}$ resulted in serum lactate level decrease by $38.9 \%$ compared to controls after 60 days, and by $36.4 \%$ by the end of the experiment. Along with a decline in serum lactate level during the chronic experiment, the inhibition of serum lactate dehydrogenase activity was detected in experimental animals. Moreover, there was a significant (by 83\%) increase in triglyceride levels upon initial exposure to DCHF.

The data obtained are indicative of potential disorders of carbohydrate and lipid metabolism in experimental rats due to prolonged inhalation exposure to DCHF concentration of $16.8 \mathrm{mg} / \mathrm{m}^{3}$.

The significant increase in alanine aminotransferase activity by $119.3 \%$ after 60 days of experiment was observed during the same period of observation, which was indicative of impaired liver function, which was back to normal by the end of the experiment.

The decrease in serum albumin levels by $79.1 \%$ in experimental rats after 60 days of exposure to $\mathrm{DCHF}$ concentration of $16.8 \mathrm{mg} / \mathrm{m}^{3}$ was observed.

According to literature [1, 2], the toxic effects of chlorobutenes are associated with dehalogenation processes, as well as with free radical formation and peroxidation. That is why the oxidant and antioxidant system status was assessed in experimental rats after 60 and 120 days of exposure to DCHF.

When performing the assessment of total antioxidant capacity (TAC), it was found, that there were no significant differences in serum hydrogen peroxide levels between the experimental animals and the controls. Blood concentration of reduced glutathione (one of the antioxidant system components) was defined in experimental rats in order to assess the total antioxidant capacity (TAC) and the total antioxidant activity.

The interest in studying the concentration of reduced glutathione is also related to bodily processes of conversion of fluorochloroalkenes by hydrolysis, and formation of glutathione conjugates. It was found that blood concentration of reduced glutathione in experimental rats upon the prolonged exposure to DCHF showed no significant changes during all periods of the study. No significant changes in TAC were revealed in experimental animals compared to controls.

Pathomorphological studies showed that by the end of chronic experiment the lung weight coefficients increased by $134.2 \%$, and liver weight coefficients increased by $113.6 \%$ in experimental animals compared to controls.

Histological examination showed that the 4-months exposure to DCHF concentration of $16.8 \mathrm{mg} / \mathrm{m} 3$ damaged lung 
parenchyma in experimental rats. Thickening of the interalveolar septa, plasma impregnation of the interalveolar septa, and hyperemia of alveolar walls were detected; accumulation of red blood cells in the alveolar lumens was observed.

Pathomorphological studies of heart, liver, kidney, spleen, and brain of experimental animals of all groups revealed no differences with the controls.

When assessing genotoxic effects of DCHF, the significant increase in the degree of damage to DNA in the bone marrow cells of experimental rats was observed.

The percentage of DNA in the tail of experimental animals was 4 times higher compared to controls $(12.5 \pm 3.03$ in the group exposed to DCHF concentration of $16.8 \mathrm{mg} / \mathrm{m}^{3}$ vs $3.1 \pm 0.6$ in the control group).

The data obtained confirm genotoxic effects of DCHF concentration of $16.8 \mathrm{mg} / \mathrm{m}^{3}$.

\section{DISCUSSION}

Thus, comprehensive studies showed that prolonged inhalation exposure of experimental rats to maximum DCHF concentrations of the tested ones $\left(16.8 \mathrm{mg} / \mathrm{m}^{3}\right)$ affected the function of nervous system (increased exploratory activity and anxiety), cardiac function (decreased bioelectric activity of the myocardium, depression of the $\mathrm{P}, \mathrm{R}, \mathrm{S}$, and $\mathrm{T}$ waves, and prolonged QT and ST intervals), and resulted in altered hematologic, biochemical, acid-base, and blood gas values, as well as in morphological alterations in lungs. Analysis of dynamic changes in the bodily processes of experimental animals when exposed to DCHF concentration of $16.8 \mathrm{mg} / \mathrm{m}^{3}$ showed significant changes in most indicators during days 30 60 of the chronic experiment. Such direction of impairments could be due to temporal activation of adaptive responses, including the DCHF detoxification systems. This assumption is supported by the results of metabolite profiling in blood plasma of experimental animals. When assessing metabolites of the substance in blood plasma of experimental animals after the 4-months exposure to DCHF concentration of $16.8 \mathrm{mg} / \mathrm{m}^{3}$, the following metabolites were detected: cysteine adduct, acetylcysteine adduct, methyl sulfide, thioketone and volatile metabolite of 1-chloro-1,1,2,3,3,4,4,4-octafluorobutane, as well as the unmetabolized form of DCHF. The data obtained are consistent with literary data [8, 9], according to which the compound fluorinated derivatives of hydrocarbons undergo metabolic transformation resulting in formation of a number of metabolites. The main DCHF transformation pathway is the formation of glutathione adducts with the further degradation of adducts to cysteine and acetylcysteine adducts. According to some sources [12], glutathione S-transferase activity resulting from action of xenobiotics can be increased by 2-6 times.

\section{References}

1. Uzhdavin JeR. Toksikologija i gigiena vysokomolekuljarnyh soedinenij i himicheskogo syr'ja. M., 1966; s. 71-72. Russian.

2. Filov VA, redaktor. Vrednye himicheskie veshhestva. Uglevodorody, galogenproizvodnye uglevodorodov: spravochnik. L.: Himija, 1990; 732 s. Russian.

3. Lazarev NV, redaktor. Vrednye himicheskie veshhestva Organicheskie veshhestva: spravochnik, T. 1. L.: Himija, 1976; 300 c. Russian.

4. Fluorocarbons in Lower Atmosphere. EOS Trans Amer Geophys Union. 1979; 60 (50): 1030.
It is also assumed that DCHF could be a chemical activator of glutathione S-transferase biosynthesis. As a result, during the chronic experiment, activation of protective and adaptive responses of the body occurs by day 90 of exposure to freon.

However, nothing would prevent the protective response disruption resulting in more pronounced clinical manifestations of intoxication. It should be noted that after the 120-day inhalation exposure to the substance concentration of $16.8 \mathrm{mg} / \mathrm{m} 3$, not only the impaired function of nervous and cardiovascular systems was observed, but also the significant alterations in a number of hematological and biochemical indicators, morphological alteration in lungs, and the signs of the substance genotoxicity.

After the 30-day recovery period following the 4-months exposure to DCHF concentration of $16.8 \mathrm{mg} / \mathrm{m}^{3}$, the changes, detected in experimental rats, persisted (reduced vertical activity, depression of R, S, T waves together with prolonged $P Q$ interval on the ECG, and changes in certain biochemical parameters: reduced serum lactate level, and increased activity of lactate dehydrogenase).

The 4-months exposure to DCHF concentration of 2.2 $\mathrm{mg} / \mathrm{m} 3$ resulted in similar, but less prominent alterations in a number of tests. Thus, when assessing behavioral responses, the increase in vertical activity by $153 \%$ and grooming by $33.3 \%$ compared to controls was observed after 30 days of the experiment. After 60 days of experimental animal exposure to $\mathrm{DCHF}$, the decrease in peripheral blood hemoglobin level by $95.3 \%$ was detected. Upon further exposure to DCHF, up to the end of the 4-months experiment, the total hemoglobin levels in experiment animals were the same as in controls.

The substance concentration of $0.24 \mathrm{mg} / \mathrm{m}^{3}$ resulted in no significant alterations of the studied parameters.

\section{CONCLUSION}

The data obtained in the course of the 4-months experiment show the adverse effects of $16.8 \mathrm{mg} / \mathrm{m}^{3} \mathrm{DCHF}$ concentration on the overall condition of the animals. Based in the extent and nature of the alterations detected, DCHF concentration of 16.8 $\mathrm{mg} / \mathrm{m}^{3}$ should be considered the effect concentration. DCHF concentration of $2.2 \mathrm{mg} / \mathrm{m}^{3}$, which causes minimum alterations in experimental animals, is considered the threshold value for rats. DCHF concentration of $0.24 \mathrm{mg} / \mathrm{m}^{3}$, which causes no significant alterations of the studied parameters, is considered the no observed effect concentration. The safety factor, calculated in accordance with the guidelines, is 12. The the maximum permissible concentration of DCHF in the air of the working area of $0.2 \mathrm{mg} / \mathrm{m}^{3}$ has been confirmed and approved based on study results; the substance has been assigned hazard class 2, $v+$ a (vapor + aerosol) + (specific protection of skin and eyes required). 
hexafluorodichlorobutene (HFCB). Fluoride. 1972; 5 (1): 4-14.

9. Gizhlarjan MS, Darbinjan NA. Metabolicheskaja aktivacija hlorzameshhennyh nenasyshhennyh soedinenij. V sbornike: Tezisy dokladov 1-go Vses. s"ezda toksikologov, Rostov-na-Donu, 1986 g. Rostov-na-Donu, 1986; s. 293-4.

10. Dekant $\mathbf{W}$, et al. Bacterial-lyase mediated cleavage and mutagenicity of cysteine conjugates derived from the nephrocarcinogenic alkenes trichloroethylene, tetrachloroethylene and hexachlorobutadiene. Chem-Biol Interact. 1986; 60: 31-45.

11. Anders MW, et al. Biosynthesis and biotransformation of glutathione S-conjugates to toxic metabolites. CRC Crit Rev Toxicol. 1988; 18: 311-41.

12. Hayes JD, Pulford DJ. The Glutathione S-Transferase Supergene Family: Regulation of GST ${ }^{\star}$ and the Contribution of the Isoenzymes to Cancer Chemoprotection and Drug Resistance Critical. Reviews in

\section{Литература}

1. Уждавин Э. Р. Токсикология и гигиена высокомолекулярных соединений и химического сырья. М., 1966; с. 71-72.

2. Филов В. А., редактор. Вредные химические вещества Углеводороды, галогенпроизводные углеводородов: справочник. Л.: Химия, 1990; 732 с.

3. Лазарев Н. В., редактор. Вредные химические вещества. Органические вещества: справочник, Т. 1. Л.: Химия, 1976; 300 с.

4. Fluorocarbons in Lower Atmosphere. EOS Trans Amer Geophys Union. 1979; 60 (50): 1030.

5. RTECS(R) National Institute for Occupational Safety and Health. Canadian Centre for Occupational Health Safety, 2005. Aailable from: https://www.cdc.gov/niosh/index.htm.

6. Clayton JW. Toxicology of the fluoroalkenes. Review and research needs Environmental Health Perspectives. 1977; 21: 255-67.

7. LockEA, Berndt WO. Studies on the Mechanism of Nephrotoxicity and Nephrocarcinogenicity of Halogenated Alkenes. CRC Critical Reviews in Toxicology. 1988; 19 (1): 23-42.

8. Truhaut R, Boudene C, Jouany J, Bouant A. Experimenta study of the toxicity of a fluoroalkene derivative, the hexafluorodichlorobutene (HFCB). Fluoride. 1972; 5 (1): 4-14.

9. Гижларян М. С., Дарбинян Н. А. Метаболическая активация хлорзамещенных ненасыщенных соединений. В сборнике: Тезисы докладов 1-го Всес. съезда токсикологов, Ростовна-Дону, 1986 г. Ростов-на-Дону, 1986; с. 293-4.

10. Dekant $W$, et al. Bacterial-lyase mediated cleavage and
Biochemistry and Molecular Biology. 1995; 30 (6): 445-600.

13. Dreehen B, Westphal G. Mutagenicity of the glutathione and cysteine $\mathrm{S}$-conjugates of the haloalkenes 1,1,2-trichloro-3,3,3trifluoro-1-propene and trichlorofluoroethene in the Ames test in comparison with the tetrachloroethene-analogues. Mutation Research. 2003; 539: 157-66.

14. Predel'no dopustimye koncentracii (PDK) vrednyh veshhestv $v$ vozduhe rabochej zony. Gigienicheskie normativy GN 2.2.5.1313 03. M.: RRPOHBV Minzdrava Rossii, 2003. Russian.

15. Predel'no dopustimye koncentracii (PDK) vrednyh veshhestv $\checkmark$ atmosfernom vozduhe naselennyh mest. Gigienicheskie normativy GN 2.1.6.1338-03. M.: STK Ajaks, 2003. Russian.

16. Metodicheskie ukazanija po ustanovleniju orientirovochnyh bezopasnyh urovnej vozdejstvija $\vee$ vozduhe rabochej zony. M., 1985. Russian.

mutagenicity of cysteine conjugates derived from the nephrocarcinogenic alkenes trichloroethylene, tetrachloroethylene and hexachlorobutadiene. Chem-Biol Interact. 1986; 60: 31-45.

11. Anders MW, et al. Biosynthesis and biotransformation of glutathione S-conjugates to toxic metabolites. CRC Crit Rev Toxicol. 1988; 18: 311-41.

12. Hayes JD, Pulford DJ. The Glutathione S-Transferase Supergene Family: Regulation of $\mathrm{GST}^{*}$ and the Contribution of the Isoenzymes to Cancer Chemoprotection and Drug Resistance Critical. Reviews in Biochemistry and Molecular Biology. 1995; 30 (6): 445-600.

13. Dreehen B, Westphal G. Mutagenicity of the glutathione and cysteine $\mathrm{S}$-conjugates of the haloalkenes 1,1,2-trichloro-3,3,3trifluoro-1-propene and trichlorofluoroethene in the Ames test in comparison with the tetrachloroethene-analogues. Mutation Research. 2003; 539: 157-66.

14. Предельно допустимые концентрации (ПДК) вредных веществ в воздухе рабочей зоны. Гигиенические нормативы ГН 2.2.5.1313 - О3. М.: РРПОХБВ Минздрава России, 2003.

15. Предельно допустимые концентрации (ПДК) вредных веществ в атмосферном воздухе населенных мест. Гигиенические нормативы ГН 2.1.6.1338-03. М.: СТК Аякс, 2003.

16. Методические указания по установлению ориентировочных безопасных уровней воздействия в воздухе рабочей зоны. M., 1985 


\title{
HYGIENIC ASSESSMENT OF THE CHEMICAL WEAPONS DESTRUCTION FACILITIES IN THE CONTEXT OF RELIEVING THE CONSEQUENCES OF THEIR OPERATION AND SUBSEQUENT CONVERSION THEREOF
}

Gulyaev DV $\otimes$

Research Institute of Hygiene, Occupational Pathology and Human Ecology FMBA, Leningrad region, Russia

\begin{abstract}
After elimination of the chemical weapons, it is necessary to relieve the consequences of operation of the chemical weapons destruction facilities (CWDF). This study aimed to assess the results of such relieve activities from the hygienic point of view. The assessment allows considering partial conversion of the CWDFs' infrastructure for civil purposes. At four CWDFs, the sites of contamination of equipment and infrastructural components with degradition products of organophosphorous agents (OPA) and blister agents (BA) were identified. The technologies that enabled analysis of the samples taken were high performance liquid chromatography with tandem mass spectrometry, gas chromatography-mass spectrometry, gas chromatography-tandem mass spectrometry, and atomic absorption spectroscopy with electrothermal atomization. The analysis revealed contamination of building structures, equipment, utility lines, waterproofing, heatinsulating, and other materials inside the CWDF process buildings, regardless of their purpose, with OPA and BA degradation products. In the absence of hygienic standards and information on their toxicity, it was impossible to assess the hazard thereof. In all the samples taken, the residual content of toxic substances was below the limit of detection of the measurement methods applied, i.e., none was found. The article presents a methodology for a stepwise hygienic assessment of the CWDF infrastructure to be converted and develops recommendations for its subsequent safe use. The conclusions state expediency of development of hygienic standards for the OPA and BA degradation products and development and certification of the relevant measurement procedures.
\end{abstract}

Keywords: chemical weapons, elimination, toxic substances, degradation products, hygiene standards, conversion

Author contribution: Gulyaev DV — study design, information collection, processing and analysis of the results, editing.

$\triangle$ Correspondence should be addressed: Dmitry V. Gulyaev

Kapitolovo, str. 93, r.p. Kuzmolovsky, Vsevolozhsky r., 188663, Leningradskaya obl.; gylya.spb@mail.ru

Received: 28.05.2021 Accepted: 13.06.2021 Published online: 25.06.2021

DOI: $10.47183 /$ mes.2021.016

\section{ГИГИЕНИЧЕСКАЯ ОЦЕНКА ОБЪЕКТОВ ПО УНИЧТОЖЕНИЮ ХИМИЧЕСКОГО ОРУЖИЯ ПРИ ЛИКВИДАЦИИ ПОСЛЕДСТВИЙ ДЕЯТЕЛЬНОСТИ И ПЕРЕПРОФИЛИРОВАНИИ}

\section{Д. В. Гуляев $\square$}

Научно-исследовательский институт гигиены, профпатологии и экологии человека Федерального медико-биологического агентства, Ленинградская область, Россия

\begin{abstract}
После уничтожения химического оружия необходимо проводить работы по ликвидации последствий деятельности объектов по уничтожению химического оружия (ОУХО). Целью работы было провести гигиеническую оценку результатов ликвидационных мероприятий для возможности вовлечения части производственной инфраструктуры ОУХО в хозяйственный оборот. На четырех ОУХО выявляли места загрязнения оборудования и элементов производственной инфраструктуры продуктами деструкции фосфорорганических отравляющих веществ (ФОВ) и отравляющих веществ кожно-нарывного действия (ОВ КНД). Пробы анализировали методами высокоэффективной жидкостной хроматографии с тандемным массселективным детектированием, газовой хроматомасс-спектрометрией, газовой хроматографии с тандемным масс-селективным детектированием и атомно-абсорбционной спектроскопии с электротермической атомизацией. Выявлено загрязнение строительных конструкций, оборудования, коммуникаций, гидроизоляционных, теплоизоляционных и других материалов, находящихся внутри производственных зданий ОУхО, вне зависимости от их предназначения, продуктами деструкции ФОВ и ОВ КНД, оценить степень опасности которых в отсутствие гигиенических нормативов и информации о токсичности не представлялось возможным. Во всех отобранных пробах остаточное содержание отравляющих веществ находилось ниже предела обнаружения методик выполнения измерений (не обнаружено). Представлена методика поэтапного гигиенического обследования необходимой к передаче инфраструктуры ОУХО с разработкой рекомендаций для последующего безопасного использования. Сделан вывод о целесообразности обоснования гигиенических нормативов продуктов деструкции ФОВ и ОВ КНД, разработки и аттестации методик выполнения измерений.
\end{abstract}

Ключевые слова: химическое оружие, ликвидация, отравляющие вещества, продукты деструкции, гигиенический норматив, перепрофилирование Вклад авторов: Д. В. Гуляев - дизайн исследования, сбор информации, обработка и анализ результатов; редактирование.

$凶$ Для корреспонденции: Дмитрий Владимирович Гуляев

г.п. Кузьмоловский, корп. 93, 188663, Всеволожский район, Ленинградская область; gylya.spb@mail.ru

Статья получена: 28.05.2021 Статья принята к печати: 13.06.2021 Опубликована онлайн: 25.06.2021

DOI: $10.47183 /$ mes.2021.016

In 1992, the Russian Federation (RF) signed the Chemical Weapons Convention (CWA) and undertook obligations to destroy chemical weapons stockpiles [1]. The country passed legislation to ensure implementation of the obligations under this international treaty $[2,3]$.

The RF had storage facilities for chemical ammunition filled with organophosphorous agents (OPA), such as $\mathrm{Vx}$, sarin, soman, and blister agents (BA), such as sulfur mustard, lewisite, and their mixtures. The chemical weapons stockpiles were destroyed at seven new chemical weapons destruction facilities (CWDF) built and commissioned at various times. The job of designing and constructing these facilities entailed development of solutions ensuring safety of operation of the CWDFs and deployment of the monitoring system that meets high requirements. There were developed regulatory and methodological documents governing organization of sanitary and epidemiological supervision and control, protection of industrial space and the environment, and health of the personnel and population.

The last piece of chemical munitions was destroyed in September 2017. Thus, the process of destroying RF's chemical weapons stockpiles was completed.

One of the problems to be solved under the Federal Target Program for the Destruction of Chemical Weapons Stockpiles 
Table 1. Number of samples taken at a CWDF

\begin{tabular}{|c|c|c|c|}
\hline CWDF & Total samples taken & Wipe samples & Solid samples of fragments of building structures and engineering infrastructure \\
\hline 1 & 218 & 62 & 156 \\
\hline 2 & 238 & 62 & 176 \\
\hline 3 & 219 & 98 & 121 \\
\hline 4 & 321 & 161 & 160 \\
\hline Total & 996 & 383 & 613 \\
\hline
\end{tabular}

in the Russian Federation [2] is relieving the consequences of operation of the chemical weapons storage and destruction facilities.

As CWDFs see the chemical weapons destruction process to completion, measures are taken to neutralize the facilities and make them safe and ready for subsequent conversion, including degassing of internal and external surfaces, dismantling equipment and building structures and cutting them into measured pieces, degassing of fragments, thermal neutralization, and waste landfilling.

Potentially, not just the destroyed chemical agents (CA) but also their toxic degradation products may contaminate building structures, equipment, utility infrastructure, waterproofing, heat-insulating, and other materials inside the buildings of facilities, which is a hazard.

The monitoring system designed to enable protection of people and the environment from the CA stays online and works during the CWDF operation consequences relieve process.

Conversion of a CWDF generates the risk of contamination of the process space and the environment with toxic substances adsorbed by the building structures and equipment.

Currently, there are active hygienic safety regulations for CAs that specify the maximum permissible concentration, MPC; maximum permissible level, MPL; tentatively safe exposure level, TSEL; approximate permissible concentration, TPC. There were also developed the methods ofmeasurement of the CA concentrations in the process space and the environment, at the site, on the skin and personal protective equipment, and in the wastes.

There were developed design documents describing the process of relieving the consequences of operation of CWDFs. These documents were reviewed and approved by the sanitary and epidemiological examination board. However, in order to preserve public funds and in the interests of industries supporting the state's defense capabilities and security (including production of gunpowders and explosives, active pharmaceutical ingredients and medicines, and waste disposal facilities treating hazard class I and II wastes), it was decided to partially preserve the process equipment and the engineering infrastructure elements signed for elimination, with the aim to convert them.

This study aimed to assess the results of such relieve activities from the hygienic point of view. The assessment allows considering partial conversion of the CWDFs' infrastructure for civil purposes, development and testing of the methodology of a phased hygienic examination necessary for the CWDF infrastructure conversion. It also enables recommendations for subsequent safe use.

\section{METHODS}

The first stage implied wipe sampling the surfaces of process equipment and elements of industrial infrastructure, collection of solid samples of fragments of building structures and elements of industrial infrastructure (floors, walls, inlet ventilation systems, power supply, lighting, heating, fire extinguishing systems) in order to identify the areas contaminated the most with the OPA and BA degradation products (Table 1; Figure).

The technologies that enabled analysis of the residual content of the OPA and BA degradation products were high performance liquid chromatography with tandem mass spectrometry (HPLC-MS/MS), gas chromatography-mass spectrometry (GC-MS), gas chromatography- tandem mass spectrometry (GC-MS/MS), and atomic absorption spectroscopy with electrothermal atomization (AAS-ETA) [4, 5].

Second stage implied wipe sampling surfaces of process equipment and elements of engineering infrastructure in order to measure the residual concentrations of OPAs and BAs by enzymatic methods and gas chromatography.

The data obtained were processed with STATISTICA 13.3 (StatSoft Inc.; USA).

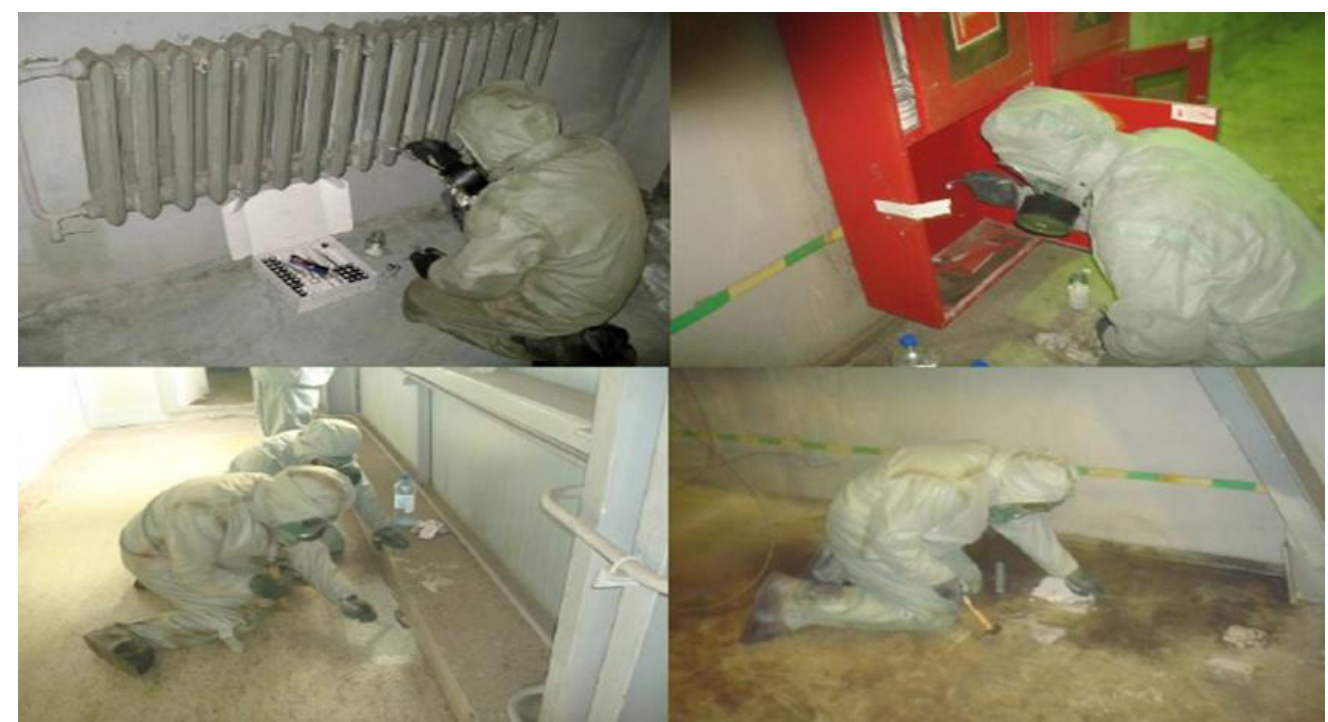

Fig. Sampling at the chemical weapons destruction facilities 
Table 2. Number of control samples taken at a CWDF

\begin{tabular}{|c|c|c|c|c|c|}
\hline \multirow{2}{*}{ CWDF } & \multicolumn{5}{|c|}{ CA identified } \\
\cline { 2 - 6 } & Vx type substance & sarin & soman & sulfur mustard & lewisite \\
\hline 1 & 118 & 107 & 118 & 39 & 39 \\
\hline 2 & 113 & 95 & 139 & - & - \\
\hline 3 & 265 & 161 & 265 & - & - \\
\hline 4 & 427 & 316 & 454 & - & - \\
\hline
\end{tabular}

\section{RESULTS}

The study yielded identification of the places (parts of equipment, engineering infrastructure) most contaminated with the OPA and BA degradation products at four CWDFs.

All the premises examined were contaminated with organic compounds typical for OPA destruction facilities: S-2(diethylaminoethyl) methylphosphonothioate, methylphosphonic acid (MPA), isopropyl-, isobutyl-, and pinacolylmethylphosphonic acid (MPA), diisobutyl, dipinacolyl, and isobutyl pinacolyl esters of MPA, and 2,2'-bis(diethylaminoethyl) disulfide.

In addition, most samples taken at facility \#1, rooms where BAs were destroyed, contained degradation products thereof: thiodiglycol, thiodiglycol oxide, and chlorovinylarsonic acid. A number of samples contained sulfur mustard. Arsenic was found in all the samples studied, with some showing values exceeding MPC and MPL.

It was not possible to assess the degree of hazard the detected chemical compounds present, since there are no relevant hygienic standards and information on toxicity.

Table 2 shows the results of analysis of control wipes taken from the surfaces (process equipment, engineering infrastructure) identified as the most contaminated with OPA and BA degradation products. The analysis aimed to determine the residual content thereof.

In all the samples taken, the residual content of OPA ( $V x$ type substance, sarin, soman) and BA (sulfur mustard, lewisite, mixtures thereof) was below the limit of detection of the measurement methods applied, i.e., none was found.

\section{DISCUSSION}

At four CWDFs, process equipment and engineering infrastructure were found to be contaminated with the OPA and BA degradation products, which indicates that the facilities were previously contaminated with the CA or with the reaction masses generated by their processing. Most likely, the compounds found in surface wipes and solid samples taken from the building structures and engineering infrastructure (wiring, cable conduits, lamps) originated from the source CA that degraded under degassing and the influence of various environmental factors (humidity, temperature etc) [4].

The study allowed compiling degassing recommendations that incorporate measures to assess the quality thereof (the degree of removal of OPA, BA, and their degradation products) after the relief operations. If it is impossible to meet the requirements of hygienic standards, it is necessary to carry out work in full in accordance with the project documentation.

To enable subsequent safe use of a CWDF, it is recommended to monitor the dynamics of the levels of OPA and BA degradation products for three years.

Development of the hygienic standards and methods to measure the CA degradation product levels (in facilities and the environment, the surface of personal protective equipment and wastes) is an important step supporting implementation of the recommendations after completion of the relief efforts at CWDFs enabling their subsequent use.

\section{CONCLUSIONS}

The analysis revealed contamination of building structures, equipment, utility lines, waterproofing, heat-insulating and other materials inside the CWDF buildings, regardless of their purpose, with products of degradation of OPA and BA. No OPA and BA were found in the wipes taken from the surfaces of process equipment and elements of the engineering infrastructure of the CWDFs. It is advisable to develop hygienic standards for OPA and BA degradation products (TSEL/ MPC in the process area air, APL/MPC on the surfaces of process equipment and PPE, APC/MPC in building structure rejects) and develop and certify the applicable measurement procedures.

\section{References}

1. Konvencija o zapreshhenii razrabotki, proizvodstva, nakoplenija i primenenija himicheskogo oruzhija i o ego unichtozhenii. Mezhdunarodnaja konferencija po podpisaniju Konvencii. GE.9261926. Parizh, 1993; 133 s. Russian.

2. Postanovlenie Pravitelstva Rossijskoj Federacii ot 21 marta 1996 g. \# 305 «Ob utverzhdenii federal'noj celevoj programmy «Unichtozhenie zapasov himicheskogo oruzhija v Rossijskoj Federacii». Sobranie zakonodatel'stva Rossijskoj Federacii. 1996; 14: 1448. Russian.

3. Federalnyj zakon ot 2 maja 1997 g. \# 76-FZ «Ob unichtozhenii himicheskogo oruzhija». Sobranie zakonodatel'stva Rossijskoj Federacii. 2006; 52: 5498. Russian.

4. Gulyaev DV, Kombarova MYu, Radilov AS, Rembovskij VR,

Saveleva El, Koryagina NL, i dr. Obespechenie sanitarnojepidemiologicheskoj bezopasnosti infrastruktury ob"ekta po unichtozheniju himicheskogo oruzhija «Pochep», planiruemogo k vovlecheniju $v$ hozjajstvennyj oborot. Medicina jekstremal'nyh situacii. 2019; 21 (4): 556-62. Russian.

5. Shmurak VI, Kessenih ED, Shachneva MD, Gustyleva LK, Aljushina TI, Korjagina NL, i dr. Opredelenie produktov destrukcii fosfororganicheskih soedinenij metodom VJeZhH-MS/MS. V sbornike: AS Radilov, VR Rembovskij, redaktory. Medikobiologicheskie aspekty himicheskoj bezopasnosti: sbornik trudov III Vserossijskoj nauchnoj konferencii molodyh uchenyh. SPb., 2018; s. 51-52. Russian. 


\section{Литература}

1. Конвенция о запрещении разработки, производства, накопления и применения химического оружия и о его уничтожении. Международная конференция по подписанию Конвенции GE.92-61926. Париж, 1993; 133 с.

2. Постановление Правительства Российской Федерации от 21 марта 1996 г. № 305 «Об утверждении федеральной целевой программы «Уничтожение запасов химического оружия в Российской Федерации". Собрание законодательства Российской Федерации. 1996; 14: 1448.

3. Федеральный закон от 2 мая 1997 г. № 76-ФЗ «Об уничтожении химического оружия». Собрание законодательства Российской Федерации. 2006; 52: 5498.

4. Гуляев Д. В., КомбароваМ. Ю., Радилов А. С., Рембовский В. Р.,
СавельеваЕ. И., КорягинаН. Л., и др. Обеспечение санитарноэпидемиологической безопасности инфраструктуры объекта по уничтожению химического оружия «Почеп», планируемого К вовлечению в хозяйственный оборот. Медицина экстремальных ситуаций. 2019; 21 (4): 556-62.

5. Шмурак В. И., Кессених Е. Д., Шачнева М. Д., Густылева Л. К. Алюшина Т. И., Корягина Н. Л., и др. Определение продуктов деструкции фосфорорганических соединений методом ВЭЖЖХ-МС/МС. В сборнике: А. С. Радилов, В. Р. Рембовский, редакторы. Медико-биологические аспекты химической безопасности: сборник трудов III Всероссийской научной конференции молодых ученых. СПб., 2018; c. $51-52$. 


\section{ORGAN-SPARING EXCISION OF PEDIATRIC TESTICULAR TERATOMA}

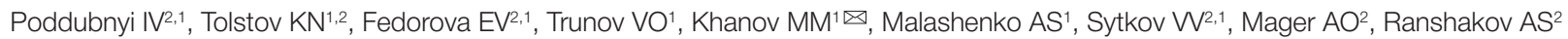

'Federal Scientific and Clinical Center for Children and Adolescents of the FMBA of Russia, Moscow, Russia

${ }^{2}$ A. I. Yevdokimov Moscow State University of Medicine and Dentistry, Moscow, Russia

Pediatric testicular masses are rare pathologies. Many physicians, facing such masses for the first time, have trouble choosing the algorithm of assessment and surgical treatment tactics. Extent of surgery and surgical approach depend directly on preoperative assessment results. The clinical case of the incident testicular mass surgical treatment in a 15-year-old boy is reported. The patient underwent laboratory and instrumental examination, the results of which confirmed a benign lesion. Based on the data obtained, the organ-sparing surgical approach was selected. An assessment algorithm, treatment tactics for testicular mass based on the data obtained, advisability and safety of the organ-sparing treatment approach are reported.

Keywords: organ-sparing surgery, testicular mass, epidermoid cyst, testicular teratoma, urology-andrology, children, pediatrics

Author contribution: Tolstov KN, Khanov MM — concept, manuscript writing; Khanov MM, Tolstov KN, Malashenko AS, Sytkov W, Mager AO, Ranshakov AS data acquisition and processing; Poddubnyi IV, Tolstov KN, Fedorova EV, Trunov VO - manuscript editing; all authors approved the final version of the article.

$\triangle$ Correspondence should be addressed: Mamai M. Khanov

Moskvorechye, 20, Moscow, 115409; 8_00@mail.ru

Received: 10.05.2021 Accepted: 24.05.2021 Published online: 05.06.2021

DOI: $10.47183 /$ mes.2021.010

\section{ОРГАНСБЕРЕГАЮЩЕЕ УДАЛЕНИЕ ТЕРАТОМЫ ЯИЧКА У РЕБЕНКА}

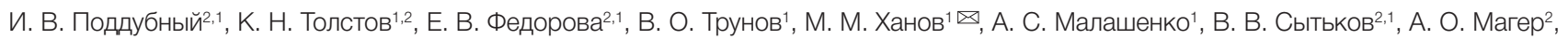
А. С. Раншаков

1 Федеральный научно-клинический центр детей и подростков Федерального медико-биологического агентства России, Москва, Россия

${ }^{2}$ Московский государственный медико-стоматологический университет имени А. И. Евдокимова, Москва, Россия

Образования яичка у детей представляют собой редкую патологию. Нередко у врачей, встречающихся с ней впервые, возникает затруднение в выборе алгоритма обследования и тактики оперативного лечения, объем и методы которого напрямую зависят от результатов предоперационного обследования. Представлен клинический случай хирургического лечения впервые выявленного образования яичка у ребенка 15 лет. Пациенту проведено лабораторно-инструментальное обследование, по результатам которого доказан доброкачественный характер образования. На основании полученных данных выбран органсохраняющий метод оперативного лечения. Представлен алгоритм обследования, тактика лечения образования яичка по результатам полученных данных, целесообразность и безопасность органсберегающего метода лечения.

Ключевые слова: органсохраняющие операции, образование яичка, эпидермальная киста, тератома яичка, урология-андрология, дети, педиатрия

Вклад авторов: К. Н. Толстов, М. М. Ханов - концепция, написание текста; М. М. Ханов, К. Н. Толстов, А. С. Малашенко, В. В. Сытьков, А. О. Магер, А. С. Раншаков - сбор и обработка материала; И. В. Поддубный, К. Н. Толстов, Е. В. Федорова, В. О. Трунов - редактирование; все соавторы утвердили окончательный вариант статьи.

$\triangle$ Для корреспонденции: Мамай Магомедханович Ханов ул. Москворечье, д. 20, г. Москва, 115409; 8_00@mail.ru

Статья получена: 10.05.2021 Статья принята к печати: 24.05.2021 Опубликована онлайн: 05.06.2021

DOI: $10.47183 /$ mes.2021.010

Pediatric testicular masses are rare: their incidence is $0.5-2.0$ cases per 100,000 people [1, 2]. Benign tumors predominate in prepubertal children, who account for about $75 \%$ of cases [2, 3]. Testicular tumors constitute $1 \%$ of all malignant tumors. In $85 \%$ of cases, testicular masses are represented by germ cell tumors [4]. Factors associated with germ cell tumors are as follows: cryptorchidism (risk increased by 5-10 times), infertility (risk increased by 10-20 times), testicular dysgenesis syndrome, germ cell tumor in a first degree relative (risk increased by 5-10 times) [5]. According to international histological classification of testicular germ cell tumors, there are following teratoma types: postpubertal teratoma; teratoma with somatic-type malignancy; prepubertal teratoma; mixed teratoma, prepubertal type [6]. Testicular epidermoid cyst is a form of prepubertal teratoma or mature teratoma, it is a benign germ cell tumor originating from one or more primary germ layers (endoderm, ectoderm and mesoderm). Testicular epidermoid cysts account for $13 \%$ of all pediatric testicular masses. Ultrasonography of the scrotum is considered the imaging modality of choice used for detection of such masses in children. In such cases ultrasonography shows 100\% sensitivity for the detection of the mass, but low specificity for the differentiation of benign and malignant tumors. During the second phase of the assessment, tumor markers and blood biochemistry are analyzed: alpha-fetoprotein (AFP), human chorionic gonadotropin (hCG), lactate dehydrogenase (LDH), and testosterone. In case of equivocal assessment results or signs of malignancy, chest computed tomography (CT) and pelvic magnetic resonance imaging (MRI) are indicated. In the absence of data on malignancy, surgical treatment is indicated. The organ-sparing approach is more and more often described as a priority in literature [3, 7-9].

The paper presents a clinical case of organ-sparing surgery in adolescent boy with benign tumor of the testicle; the algorithm of physician's actions in case of testicular tumor detection is reported.

\section{Clinical case}

Adolescent boy M. aged 15. Physical examination found a hard consistency, elastic, painless mass detected by palpation in the lower pole of the left testicle. The scrotum appeared normal in size; testicle was mobile, of elastic consistency; the mass did not adhere to the surrounding tissue; left testicular veins 


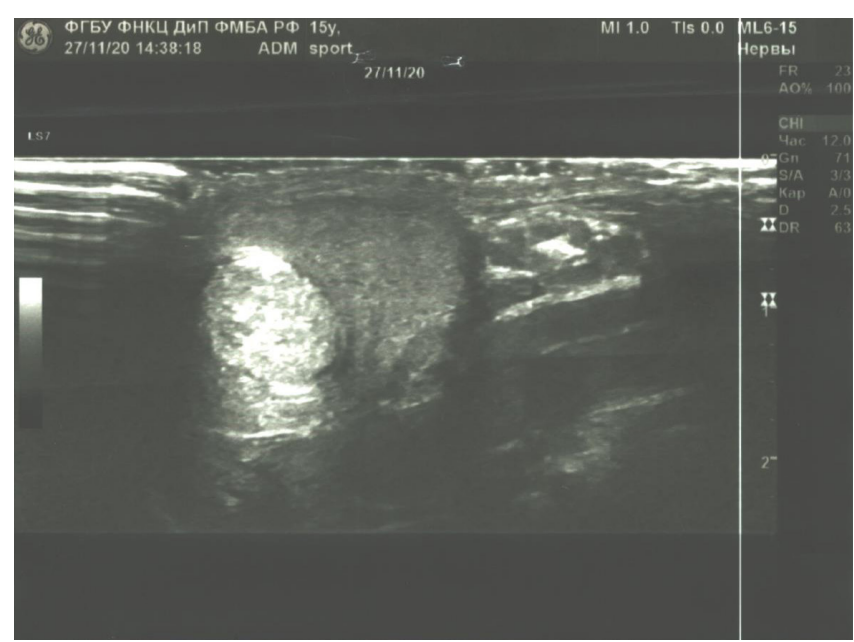

Fig. 1. Ultrasonogram 1. Ultrasound features of avascular lesion of the lower pole of the testis

were not dilated. The patient had no clinical manifestations of the mass, and no history of trauma. The boy was hospitalized in the hospital of the Federal Scientific and Clinical Center for Children and Adolescents of the FMBA of Russia for further assessment and treatment.

\section{Laboratory and instrumental examinations}

The boy underwent scrotal ultrasonography, which revealed a $10.6 \times 9.4 \times 9.2 \mathrm{~mm}$ encapsulated mass of the lower pole of the left testicle with clear, well-defined edges with no signs of spreading into surrounding tissues. Doppler ultrasonography of the mass revealed no detectable blood flow (Fig. 1 and 2).

Blood levels of AFP, b-HCG, LDH, and testosterone were normal.

MRI of pelvic organs and external genitalia was performed due to suspected malignancy (Fig. 3 and 4); no invasion of surrounding tissue or spread to regional lymph nodes and pelvic organs was detected. The $8 \mathrm{~mm}$ mass of the lower pole of the left testicle was revealed, no other pathological features were seen.

The boy got the consultation of oncologist at the N.N. Blokhin National Medical Research Center of Oncology; the testis-sparing excision of the mass was indicated.

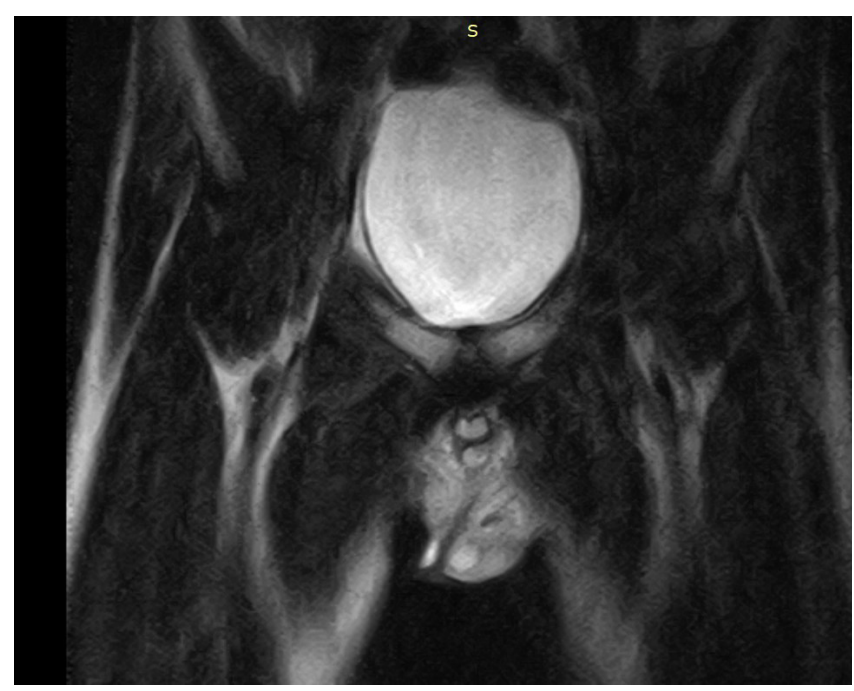

Fig. 3. MRI scan 1. MRI features of left testicular lesion with no signs of tumor spreading to pelvic organs and regional lymph nodes

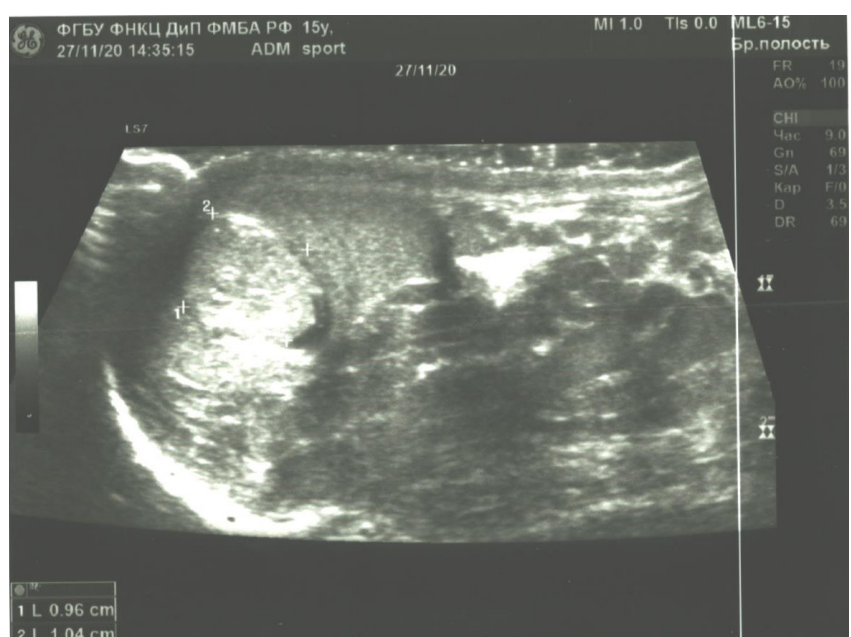

Fig. 2. Ultrasonogram 2. Ultrasound features of avascular lesion of the lower pole of the testis

\section{Surgical treatment}

Dissection of the testicular membranes through trans-scrotal incision was performed with the patient supine under general anesthesia, the small amount of clear exudate was produced. Surgical exploration revealed no changes in testicular tissue. Testicular tissue was dissected in the lower pole, in the projection of the suspected mass. At depth of 5-7 mm the rounded mass with well differentiated capsule slightly adhered to surrounding tissues was seen. Mobilization and excision of the mass were performed step-by-step with blunt/sharp instruments with the use of monopolar coagulation (Fig. 5). The mass was sent for histological examination, testicular membranes and scrotal skin were closed with sutures. Histological examination revealed the epidermoid cyst (prepubertal teratoma).

\section{Post-operative period}

The boy was transferred from the operative room to surgery department for follow-up and planned analgesic therapy. The postoperative period was uneventful, no surgical complications were observed. The follow-up ultrasonography revealed a contents-free residual cavity about $4 \mathrm{~mm}$ in diameter in the projection of the excised mass. The patient was discharged two days after surgery. The follow-up ultrasound examination

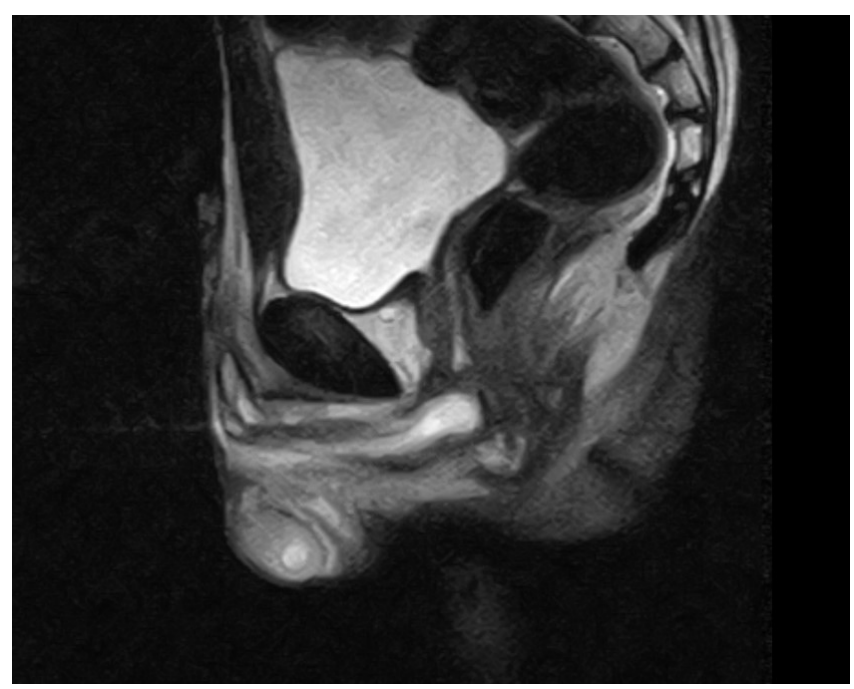

Fig. 4. MRI scan 2. MRI features of left testicular lesion with no signs of tumor spreading to pelvic organs and regional lymph nodes 
of the scrotum every two months was recommended. The scrotal ultrasonography results, obtained 2, 4 and 6 months after surgery, showed no evidence of the tumor recurrence. Ultrasound examination of the scrotum every six months was recommended.

\section{Discussion}

Surgery is a modality of choice for pediatric benign tumors. Concerning the data obtained during the previous years, as well as the experience of "adult" urologists, high inguinal orchifuniculectomy had been performed for a long time due to suspected malignancy, or removal of testicle after testicular biopsy in case of histologically proven benign lesion [10, 11] Taking into account the fact that recent findings demonstrate the predominance of benign neoplasms among testicular tumors, as well as based on the results of 5-year follow-up study in children after enucleation of testicular masses, the organsparing surgery may be considered as a modality of choice for benign testicular tumors [3, 7-9]. The organ-sparing approach is applied when there is no data confirming malignancy, and for small-sized tumors.

Radical inguinal orchofuniculectomy is advisable in cases of proven malignant nature of the mass [10].

\section{Conclusion}

Epidermoid cyst is a benign testicular tumor, usually having no clinical manifestations. Upon detection of testicular mass

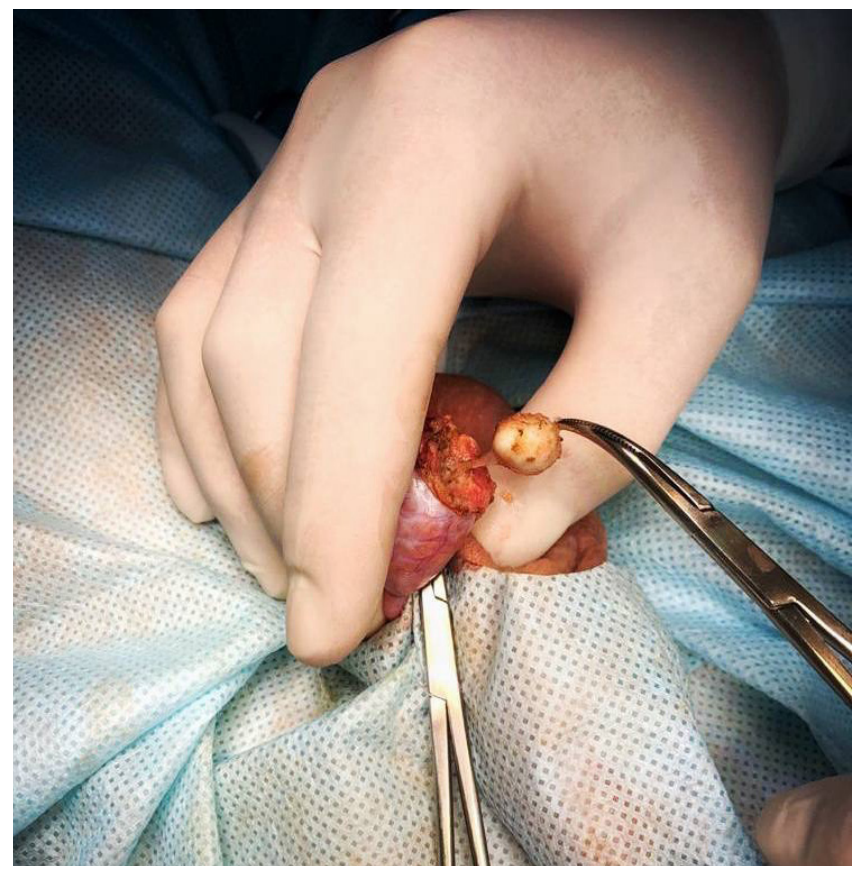

Fig. 5. Intraoperative image. Excision of encapsulated testicular teratoma

and performing a number of diagnostic procedures to confirm a benign lesion, surgical treatment is indicated. Trans-scrotal testis-sparing enucleation of the mass is a modality of choice for benign lesions less than $3 \mathrm{~cm}$ in size.

\section{References}

1. Pohl HG, Shukla AR, Metcalf PD, Cilento BG, Retik AB, Bagli DJ, Huff DS, Rushton HG. Prepubertal testis tumors: actual prevalence rate of histological types. J Urol. 2004 Dec; 172 (6 Pt 1): 2370-2. DOI: 10.1097/01.ju.0000144402.13556.74. PMID: 15538270.

2. Walsh TJ, Grady RW, Porter MP, Lin DW, Weiss NS. Incidence of testicular germ cell cancers in U.S. children: SEER program experience 1973 to 2000. Urology. 2006 Aug; 68 (2): 402-5: discussion 405. DOI: 10.1016/j.urology.2006.02.045. PMID: 16904461

3. Chung JM, Lee SD. Overview of pediatric testicular tumors in Korea. Korean J Urol. 2014 Dec; 55 (12): 789-96. DOl: 10.4111/ kju.2014.55.12.789. Epub 2014 Dec 5. PMID: 25512812; PMCID: PMC4265712.

4. Gill MS, Shah SH, Soomro IN, Kayani N, Hasan SH. Morphological pattern of testicular tumors. J Pak Med Assoc. 2000 Apr; 50 (4): 110-3. PMID: 10851829.

5. Germinogennye opuholi u muzhchin. Klinicheskie rekomendacii. Ministerstvo zdravoohranenija RF, 2020 g. Dostupno po ssylke: https://nop2030.ru/files/2019/08/048.pdf. Russian.

6. Williamson SR, Delahunt B, Magi-Galluzzi C, Algaba F, Egevad L, Ulbright TM, et al. The World Health Organization 2016 classification of testicular germ cell tumours: a review and update

\section{Литература}

1. Pohl HG, Shukla AR, Metcalf PD, Cilento BG, Retik AB, Bagli DJ, Huff DS, Rushton HG. Prepubertal testis tumors: actual prevalence rate of histological types. J Urol. 2004 Dec; 172 (6 Pt 1): 2370-2 DOI: 10.1097/01.ju.0000144402.13556.74. PMID: 15538270.

2. Walsh TJ, Grady RW, Porter MP, Lin DW, Weiss NS. Incidence of testicular germ cell cancers in U.S. children: SEER program experience 1973 to 2000. Urology. 2006 Aug; 68 (2): 402-5; discussion 405. DOI: 10.1016/j.urology.2006.02.045. PMID:

from the International Society of Urological Pathology Testis Consultation Panel. Available from: https://onlinelibrary.wiley. com/doi/abs/10.1111/his.13102.

7. Sangüesa C, Veiga D, Llavador M, Serrano A. Testicular tumours in children: an approach to diagnosis and management with pathologic correlation. Insights Imaging. 2020; 11 (1): 74. Published 2020 May 27. DOI: 10.1186/s13244-020-00867-6.

8. Romo Muñoz MI, Núñez Cerezo V, Dore Reyes M, Vilanova Sánchez A, González-Peramato P, López Pereira P, et al. Tumores testiculares en la edad pediátrica: indicaciones de la cirugía conservadora Testicular tumours in children: Indications for testis-sparing surgery]. An Pediatr (Barc). 2018 May; 88 (5): 253-8. DOI: 10.1016/j.anpedi.2017.05.009. Epub 2017 Jul 17. PMID: 28729185. Spanish.

9. Kooij CD, Hulsker CCC, Kranendonk MEG, et al. Testis Sparing Surgery in Pediatric Testicular Tumors. Cancers (Basel). 2020; 12 (10): 2867. Published 2020 Oct 6. DOI: 10.3390/ cancers12102867.

10. Rohoev M. A. Opuholi jaichka i paratestikuljarnye opuholi u detej. Diagnostika, lechenie [dissertacija]. M., 2014. Russian.

11. Brosman SA. Testicular tumors in prepubertal children. Urology. 1979; 13 (6): 581-8.

16904461

3. Chung JM, Lee SD. Overview of pediatric testicular tumors in Korea. Korean J Urol. 2014 Dec; 55 (12): 789-96. DOI: 10.4111/ kju.2014.55.12.789. Epub 2014 Dec 5. PMID: 25512812; PMCID: PMC4265712.

4. Gill MS, Shah SH, Soomro IN, Kayani N, Hasan SH. Morphological pattern of testicular tumors. J Pak Med Assoc. 2000 Apr; 50 (4): 110-3. PMID: 10851829. 
5. Герминогенные опухоли у мужчин. Клинические рекомендации. Министерство здравоохранения РФ, 2020 г. Доступно по ссылке: https://nop2030.ru/files/2019/08/048.pdf.

6. Williamson SR, Delahunt B, Magi-Galluzzi C, Algaba F, Egevad L, Ulbright TM, et al. The World Health Organization 2016 classification of testicular germ cell tumours: a review and update from the International Society of Urological Pathology Testis Consultation Panel. Available from: https://onlinelibrary.wiley. com/doi/abs/10.1111/his.13102.

7. Sangüesa C, Veiga D, Llavador M, Serrano A. Testicular tumours in children: an approach to diagnosis and management with pathologic correlation. Insights Imaging. 2020; 11 (1): 74 Published 2020 May 27. DOl: 10.1186/s13244-020-00867-6.

8. Romo Muñoz MI, Núñez Cerezo V, Dore Reyes M, Vilanova
Sánchez A, González-Peramato P, López Pereira $\mathrm{P}$, et al. Tumores testiculares en la edad pediátrica: indicaciones de la cirugía conservadora [Testicular tumours in children: Indications for testis-sparing surgery]. An Pediatr (Barc). 2018 May; 88 (5): 253-8. DOl: 10.1016/j.anpedi.2017.05.009. Epub 2017 Jul 17. PMID: 28729185. Spanish.

9. Kooij CD, Hulsker CCC, Kranendonk MEG, et al. Testis Sparing Surgery in Pediatric Testicular Tumors. Cancers (Basel). 2020; 12 (10): 2867. Published 2020 Oct 6. DOI: 10.3390/ cancers12102867.

10. Рохоев М. А. Опухоли яичка и паратестикулярные опухоли у детей. Диагностика, лечение [диссертация]. М., 2014.

11. Brosman SA. Testicular tumors in prepubertal children. Urology. 1979; 13 (6): 581-8. 